\title{
To Accommodate or Not to Accommodate: (When) Should the State Regulate Religion to Protect the Rights of Children and Third Parties?
}

Hillel Y. Levin

University of Georgia School of Law, hlevin@uga.edu

Allan J. Jacobs

State University of New York

Kavita Arora

Case Western Reserve University

P bepress

\section{Repository Citation}

Hillel Y. Levin, Allan J. Jacobs, and Kavita Arora, To Accommodate or Not to Accommodate: (When) Should the State Regulate Religion to Protect the Rights of Children and Third Parties? , 73 Wash. \& Lee L. Rev. 915 (2016),

Available at: https://digitalcommons.law.uga.edu/fac_artchop/1065

This Article is brought to you for free and open access by the Faculty Scholarship at Digital Commons @ University of Georgia School of Law. It has been accepted for inclusion in Scholarly Works by an authorized administrator of Digital Commons @ University of Georgia School of Law. Please share how you have benefited from this access For more information, please contact tstriepe@uga.edu. 


\title{
To Accommodate or Not to Accommodate: (When) Should the State Regulate Religion to Protect the Rights of Children and Third Parties?
}

\author{
Hillel Y. Levin* \\ Allan J. Jacobs** \\ Kavita Shah Arora***
}

\begin{abstract}
When should we accommodate religious practices? When should we demand that religious groups instead conform to social or legal norms? Who should make these decisions, and how? These questions lie at the very heart of our contemporary debates in the field of Law and Religion.

Particularly thorny issues arise where religious practices may impose health-related harm to children within a religious group or to third parties. Unfortunately, legislators, courts, scholars, ethicists, and medical practitioners have not offered a consistent way to analyze such cases, so the law is inconsistent. This Article suggests, first, that the lack of consistency is a troubling artifact of our political system, and, second, that it raises serious

* Hillel Y. Levin is Associate Professor of Law at the University of Georgia School of Law.

** Allan J. Jacobs is Director of Gynecologic Oncology at Coney Island Hospital and Professor of Obstetrics and Gynecology and Associate Faculty in Bioethics, Stony Brook University.

*** Kavita Shah Arora is Assistant Professor of Reproductive Biology and Bioethics at Case Western Reserve University-MetroHealth Medical Center.

The authors are grateful to Nelson Tebbe, Rick Garnett, Andy Koppelman, Kent Greenawalt, Micah Schwartzman, Alan Brownstein, Jacob Levy, Sarah Barringer Gordon, Bill Marshall, Víctor Muñiz-Fraticelli, Jay Wexler, Winni Sullivan, and all of the participants at the 2015 Annual Law and Religion Roundtable for their comments on earlier drafts of the paper. The authors also thank Nick Kinsley of the University of Georgia School of Law for his excellent research assistance.
\end{abstract}


constitutional questions that lie at the intersection of the Free Exercise and Establishment Clauses of the First Amendment.

To resolve these problems, we offer and develop a test to determine whether such a religious practice should be accommodated by legislators, courts, and medical practitioners. Our test is sensitive to the institutional strengths and weaknesses of differently situated decision makers and is designed to be flexible enough to account for these differences. Consequently, it has distinctive applications for legislators, administrative officials, judges, and medical practitioners. Further, although the test was developed specifically to address religious practices that may impose health-related harms to children and third-parties, it also has potential implications in other contexts as well, such as the debate over whether sexual orientation non-discrimination laws should accommodate religious dissent.

\section{Table of Contents}

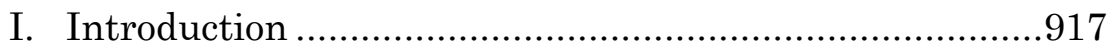

II. To Accommodate or Not to Accommodate?

A. Accommodation vs. Non-Accommodation: The Scholarly Debates

B. Accommodation vs. Non-Accommodation: Tracing the Supreme Court's Approach

C. Beyond Philosophy and Constitutionalism: Accommodationism Today

1. Constitutional Expressions of Accommodationism and Their Limits

2. Statutory Expressions of

Accommodationism and Their Limits

III. Understanding Inconsistency: Religious

Accommodation and Non-Accommodation in the

Political Economy

A. Is Inconsistency Troubling? In This Case, Yes.

B. Explaining Inconsistency: Religious Groups in the Political Economy....

C. The Problems with Leaving Accommodations to Politics 
IV. Balancing Religious Liberty Against Protection of Children and Third Parties: A Proposed Test

A. The Test .966

B. Explaining the Test ................................................968

1. The Thrust of the Test and Its Audience ............968

2. Unpacking the Test: Explanations and

Definitions.....

a. Identifying a "Religious Practice" .................971

b. Identifying a "Religious Group"

c. The Types of Risks, Burdens, Harms, and Costs Contemplated by the Test

d. The Likelihood of Burdens Associated with the Test.

e. The Magnitude Limitation: Tolerance of Harmful Mainstream Practices Requires Tolerance of Comparably Harmful Religious Practices 988

C. The Test in Action ...................................................993

1. Cases Involving Religious Practices That Allegedly Harm In-Group Children.

2. Cases Involving Potential Harm to Third Parties 1001

V. The Test's Implications and Limitations 1005

A. The Test Primarily Applies Only to a Limited Category of Cases, but It May Have Important Implications for Many Others 1005

B. The Test Does Not Always Mandate the Prohibition of Religious Practices, Even Where Its Conditions Are Met 1008

C. The Test Does Not Resolve All Cases in Which It Applies

VI. Conclusion 1016

\section{Introduction}

To accommodate or not to accommodate religious beliefsthat is the question that dominates the field of Law and Religion 
today. ${ }^{1}$ It is a question that confronts all modern liberal societies, and the space for accommodating religious objections to general legal obligations is increasingly contested in contemporary American legal, political, and ethical discourse.

This problem is especially acute where the majority culture perceives a religious practice or requirement to impose risks, harms, burdens, or costs on children. ${ }^{2}$ A parent's refusal to supply medical treatment to a child may lead to the death of the child. ${ }^{3}$ Parents who refuse to vaccinate a child due to the demands of their religion or conscience can put their child at grave risk, as well as other children across society who cannot be vaccinated. ${ }^{4}$ Opponents of ritual male infant circumcision controversially assert that it causes intolerable pain, inhibits future sexual pleasure, and violates autonomy. ${ }^{5}$ Many more

1. See, e.g., Hillel Levin, Rethinking Religious Minorities' Political Power, 48 U.C. DAVIS L. REV. 1617, 1619 (2015) [hereinafter Levin, Rethinking Religious Minorities] (noting several recent court cases involving religious accommodation).

2. See, e.g., Allan J. Jacobs, Do Belief Exemptions to Compulsory Vaccination Programs Violate the Fourteenth Amendment?, 42 U. MEM. L. REV. 73, 76 (2011) (explaining that exemptions from vaccination can result in an epidemic); Lesley Stone, Lance Gable \& Tara Gingerich, When the Right to Health and the Right to Religion Conflict: A Human Rights Analysis, $12 \mathrm{MICH}$. ST. J. INT'L. L. 247, 305 (2004) (explaining that religious exemptions reduce immunization rates, making it more difficult to protect public health); Eliana Dockterman, Faith-Healing Parents Jailed After Second Child's Death, Time (Feb. 19, 2014), http://time.com/8750/faith-healing-parents-jailed-after-secondchilds-death/ (last visited Dec. 30, 2015) (reporting that parents were sent to jail after their second child died as a result of their refusal to take him to the doctor) (on file with the Washington and Lee Law Review).

3. See, e.g., Dockterman, supra note 2 (describing the case of the Schaible family, whose two young sons died from pneumonia when their parents refused to provide medical care).

4. See Jacobs, supra note 2, at 79 ("Vaccination of an individual benefits not just the vaccinated person but all susceptible persons in the community."); Stone, Gable \& Gingerich, supra note 2, at 305 ("Religious exemptions from immunization requirements reduce these immunization rates and may make it difficult to achieve the necessary levels of immunity to protect public health. An under-immunized population is more susceptible to an infectious disease outbreak. Indeed, the risk of an outbreak increases as immunization rates decrease.").

5. See Martha Groves, Male Circumcision Opponents Propose Ballot Measure in Santa Monica, L.A. TIMES (May 25, 2011), http://articles. latimes.com/2011/may/25/local/la-me-circumcision-ban-20110525 (last visited Dec. 30, 2015) (stating that opponents to male circumcision believe it is a painful and unnecessary procedure, and that the children should be protected) 
attack female genital alteration ${ }^{6}$ on similar grounds. ${ }^{7}$ Some oppose the practice of homeschooling children, ostensibly out of concern that school attendance provides necessary socializing and educational experiences. ${ }^{8}$ Should society give religious groups and individuals special exemptions in such circumstances?

Unfortunately, there is little consistency in either the politics or the law surrounding such questions. Neither courts nor scholars have offered systematic approaches for resolving these questions in a manner that dignifies the competing underlying values in the debate-religious minorities' right to practice according to their beliefs versus society's interest in protecting the vulnerable and in enforcing its rules evenhandedly.

Moreover, these conflicts also have important constitutional dimensions. On the one hand, religious believers may look to the Free Exercise Clause ${ }^{9}$ (as well as related federal and state statutes and state constitutional provisions), the constitutional right to raise one's children as one sees fit, and constitutional principles of non-discrimination for support for their religious liberty claims. ${ }^{10}$ On the other hand, there are serious

(on file with the Washington and Lee Law Review).

6. See generally I. Utz-Billing \& H. Kentenich, Female Genital Mutilation: An Injury, Physical and Mental Harm, 29 J. Psychosomatic Obstetrics \& GYNECOLOGY 225 (2008) (providing an overview of female genital alteration).

7. See generally Kavita Shah Arora \& Allan J. Jacobs, Female Genital Alteration: A Compromise Solution, 42 J. Med. EтHICs 148 (2016) (reviewing the ethics and policy surrounding female genital alteration); Edith M. Lederer, United Nations Calls for Global Ban on Female Genital Mutilation, HufFingtoN Post (Nov. 27, 2012), http://www.huffingtonpost.com/2012/11/27/un-committeecalls-for-ba_0_n _2198244.html (last visited Dec. 30, 2015) (stating that the opponents of female genital mutilation describe it as "harmful and a serious threat to the psychological, sexual, and reproductive health of women and girls") (on file with the Washington and Lee Law Review). But see generally Arora \& Jacobs, supra note 7 (describing forms of female genital alteration with little effect on the recipient).

8. See Judith G. McMullen, Behind Closed Doors: Should States Regulate Homeschooling?, 54 S.C. L. REv. 75, 83 (2002) (describing the argument that homeschooling deprives children of social interaction and inhibits development of teamwork and collaboration skills).

9. See U.S. Const. amend I ("Congress shall make no law respecting an establishment of religion, or prohibiting the free exercise thereof . ...").

10. See, e.g., Meyer v. Nebraska, 262 U.S. 390, 403 (1923) (concluding that Nebraska's state statute prohibiting the teaching of a foreign language to someone who had not yet passed the eighth grade infringed upon a person's liberty interest under the Fourteenth Amendment); Pierce v. Soc'y of Sisters, 
Establishment Clause concerns with accommodating religious believers in a manner that harms others. ${ }^{11}$

This Article aims to correct this deficiency by offering a test to balance our society's commitment to pluralism and liberty against our interest in protecting children and third parties in a principled and consistent manner. Although the test was developed in the healthcare and childcare contexts, it also has potential implications for other kinds of conflicts between religion and state as well. ${ }^{12}$ It provides, for example, a possible approach to the politically polarizing question of whether antidiscrimination laws that protect people on the basis of sexual orientation should include religious exemptions. ${ }^{13}$

The Article proceeds as follows: Part II briefly reviews the constitutional and statutory law of religious accommodation and the related academic debates. ${ }^{14}$ It also shows that American law is inconsistent in the way in which it balances the values implicated in the debate over accommodation versus non-accommodation. Part III considers some troubling aspects of this inconsistency. ${ }^{15}$ This Part also applies insights of public choice theory to assess why lawmakers sometimes over-embrace religious accommodation by permitting minority religious practices to persist even when they harm third parties, but sometimes under-embrace it by prohibiting minority religious practices that impose few costs on society. This Part concludes by calling for a principled approach to these questions.

268 U.S. 510, 536 (1925) (concluding that Oregon's Compulsory Education Act unreasonably interfered with the liberty of parents and guardians to direct the upbringing and education of their children); Troxel v. Granville, 530 U.S. 57, 101-02 (2000) (concluding that the Due Process Clause of the Fourteenth Amendment did not permit a state to infringe on the fundamental right of parents to make child-rearing decisions).

11. See Levin, Rethinking Religious Minorities, supra note 1, at 1682-83 (describing the complex issues associated with balancing religious liberty and the general public interest).

12. See infra Part IV (establishing a balancing test that considers certain religious practices and resulting health and safety concerns).

13. Infra Part IV.

14. Infra Part II.

15. Infra Part III. 
Part IV proceeds to articulate and develop a test for resolving these conflicts. ${ }^{16}$ It shows how the test may be used by differently situated decision-makers in a manner that plays to their institutional strengths. It explores how the test appropriately mediates between the competing philosophical values at stake and aids in sorting out the complex interplay between different constitutional norms. This Part concludes by illustrating application of the test in a variety of contexts. Part V considers several implications and limitations of, as well as possible objections to, the test. The Article concludes by highlighting several benefits of the test.

\section{To Accommodate or Not to Accommodate?}

Every society must choose whether and how to accommodate, celebrate, or undermine religious sub-communities' distinctive identities and practices within the larger polity. ${ }^{17}$ In this Part, we

16. Infra Part IV.

17. Two related issues that we will not address are (1) what constitutes religion and (2) which religions deserve government recognition. Religion may be regarded alternatively as theistic belief systems, in which a Divine presence with a will governs or influences the world. See, e.g., Genesis 1:3 ("And God said, Let there be light: and there was light."); John 3:16 ("For God so loved the world, that he gave his only begotten Son, that whosoever believeth in him should not perish, but have everlasting life."). Other belief systems involve transcendental or numinous concepts, see, e.g., Charles TAliaferro, A Companion to Philosophy of Religion 640-41 (2d ed., 2010) (discussing the reincarnation and karma belief systems), or any entity or belief that "speak[s] of the depths of your life, of the source of your being, of your ultimate concern, of what you take seriously without any reservation." United States v. Seeger, 380 U.S. 163, 187 (1965) (quoting PAUl Tillich, The Shaking OF THE Foundations 57 (1948)). We do not choose among these and other alternative definitions.

As for the question of which religions deserve government recognition, the Establishment Clause forbids the government from officially recognizing or privileging any religion or religious group over others. See U.S. CONST. amend. I ("Congress shall make no law respecting an establishment of religion, or prohibiting the free exercise thereof ....”). Further, as we will discuss, a single religion may have different groups, sects, or denominations within it, all of which are owed equal treatment by the government. Id. Cases have suggested that even idiosyncratic religious beliefs, if sincerely held, are entitled to the same respect as established religions. See Ben-Levi v. Brown, 136 S. Ct. 930, 932 (2016) (Alito, J., dissenting) (stressing that the lower courts improperly found that Ben-Levi's religious exercise was not burdened because he "misunderstands his own religion"); Holt v. Hobbs, 135 S. Ct. 853, 862 (2015) 
(noting that the Religious Land Use and Institutionalized Persons Act protects "any exercise of religion, whether or not compelled by or central to a system of religious belief" (citation omitted)); Cutter v. Wilkinson, 544 U.S. 709, 723-24 (2005) (upholding the Religious Land Use and Institutionalized Persons Act (RLUIPA) where inmates from non-mainstream religions challenged the prison's refusal to accommodate their religious needs). Some cases and scholars have gone so far as to suggest that non-transcendental beliefs of conscience are also to be treated as "religious" for statutory or constitutional purposes. See generally Seeger, 380 U.S. at 187; Kent Greenawalt, The Significance of Conscience, 47 SAN Diego L. REV. 901, 917-18 (2010). For a brief review of the literature about the relationship between freedom of conscience claims and freedom of religion claims, see Nathan S. Chapman, Disentangling Conscience and Religion, 2013 U. ILL. L. REV. 1457, 1459-61 (2013). Chapman's Article goes on to thoughtfully address this relationship in greater detail. Id.

On the other hand, some contemporary Western states recognize official religions and thus have a relatively narrow definition of which religions deserve government recognition. Other states, such as those in the former Soviet bloc, place open religious expression that does not take place under the aegis of government-sanctioned religious groups at serious legal disadvantage (e.g., Russia, Hungary). See International Religious Freedom Report for 2014, U.S. DEP'T OF STATE (2014), http://www.state.gov/j/drl/rls/irf/religiousfreedom/index. htm\#wrapper (last visited Feb. 12, 2016) (noting the difficulties faced by non-government sanctioned religious groups) (on file with the Washington and Lee Law Review). More liberal states have, at times, discriminated against religious bodies that do not fully accept government legitimacy (e.g., Jehovah's Witnesses, Scientology). See generally Keturah A. Dunner, Comment, Addressing Religious Intolerance in Europe: The Limited Application of Article 9 of the European Convention of Human Rights and Fundamental Freedoms, 30 CAL. W. INT'L. L.J. 117 (1999) (noting discriminatory actions taken by the government against perceived "dangerous" religious groups). Our focus in this Article, however, is on American law, which does not assign some religious bodies greater legitimacy than others. U.S. ConsT. amend. I.

There is a rich scholarly literature debating these issues and the difficult questions they raise. See, e.g., Stanley Ingber, Religion or Ideology: A Needed Clarification of the Religion Clauses, 41 STAN. L. REV. 233, 234 (1989) ("In spite of the concept's antiquity, courts and scholars continue to battle over what does and does not constitute a religion."); Jeffrey Omar Usman, Defining Religion: The Struggle to Define Religion Under the First Amendment and the Contributions and Insights of Other Disciplines of Study Including Theology, Psychology, Sociology, the Arts, and Anthropology, 83 N.D. L. REV. 123, 126 (2007) (debating what exactly constitutes religion in the United States). In the spirit of candor, we note that even the authors of this Article have different instincts concerning these issues. One of us has a provisionally narrow view of what constitutes "religion" in American law, while the other two lean toward a broader or even maximalist definition. All of us recognize the difficulties in each possible approach.

In any event, the focus of this Article is not on defining religion. Instead, we address a different question: given a practice that is understood to be religiousunder any specific operative definition-when should the government tolerate the practice if it imposes harms on the children of the religious practitioners or 
review the scholarly literature and the Supreme Court's jurisprudence on how American constitutional law should and does resolve these questions. Because these debates and doctrines are familiar to scholars and students, our review of the literature and law is brief.

We conclude this Part by suggesting that the United States has privileged accommodationism over non-accommodationism in constitutional and statutory law as compared with other Western democracies, though its accommodationist stance is inconsistent. ${ }^{18}$

\section{A. Accommodation vs. Non-Accommodation: The Scholarly Debates}

From a broad and abstract perspective, the question of whether to accommodate religious groups' special needs and practices can be seen as part of a broader question. Should society generally demand conformity and assimilation to liberal norms and policies preferred by the majority, or-taking a "live and let live" approach—should the law allow minority and nonconformist groups and individuals to live their lives and order their communities as they see fit? This question extends well beyond the issue of accommodation of religious practices. The broader question is one of political philosophy, and political philosophers and others have had a good deal to say about it. ${ }^{19}$ It follows that

on third parties?

18. Compare infra notes 31-43, 125-129 and accompanying text (noting that Congress enacted-with near unanimity-the Religious Freedom Restoration Act (RFRA) and the Religious Land Use and Institutionalized Persons Act (RLUIPA), which subject even incidental restrictions on religious groups to strict scrutiny, thereby requiring frequent special accommodations and exceptions for religious groups), with infra notes 44-47, 130-141 and accompanying text (noting issues and situations where American law is not so deferential to religious beliefs, such as those involving discrimination, animus, mistrust, indifference, lack of awareness, or political self-interest).

19. Paul Weithman characterizes liberal democracy as entailing "moral commitments which are in some way normative for its citizens. Among the most important of these are commitments to liberty and equality, religion toleration, self-government, majoritarianism, the rule of law, and some measure of church-state separation. The precise content and implications of these commitments are matters of disagreement." PAUL J. WEITHMAN, RELIGION AND THE OBLigAtions of Citizenship 1 (2002). While all self-described liberals would 
likely agree with each of these principles in the abstract, when the principles conflict with one another-as they do in the conflicts between majority practices and non-conformists' groups practices-different philosophical instincts lead in different directions. See generally Gregory Fernando Pappas, Pragmatism in THE AMERICAS 231 (2011).

Two liberal-democratic impulses, those that enshrine majority rule and equality together reflect a general privileging of the non-accommodationist viewpoint, which roughly correlates with the familiar "melting pot" metaphor for social integration. See id. at 231 ("For the cultural monist, the idea of the 'melting pot' ought to be the model for dealing with newcomers to American culture."). Society, through its elected leaders, determines its own values and makes laws consistent with those values. Those laws, in turn, apply equally to all, regardless of the individual's own views as to the relative merits of the laws and their underlying values.

But two of liberalism's other core values are personal autonomy and freedom. Even those who do not adhere to the Millian harm principle would likely regard personal liberty as at least a prima facie good. See JOHN STUART MiLL, ON LIBERTY 6 (1913) ("[T]he only purpose for which power can be rightfully exercised over any member of a civilized community, against his will, is to prevent harm to others."). Even those espousing the most non-accommodationist position would temper these pure majority rules and equality instincts with a concern for individual rights and freedoms. More controversial is multiculturalism - the idea that groups themselves have rights or prerogatives. See generally CHARLES TAYLOR, EXAMINING THE POLITICS OF ReCognition IN MULTiculturalism 25 (Amy Gutmann ed. 1994) (explaining multiculturalism and its different implications). This can be manifested in one of several ways. Groups may have powers over their members, such as religious control over family law in some nations. Id. Individuals within those groups may either deserve exemption from general laws, for example, by being allowed to use their own language, or may not be entitled to protection of the laws against some actions of their cultural group or its members. $I d$.

However, liberal monists-what Richard Shweder calls imperial liberalsinsist that liberal ways of life "are objectively more valuable than illiberal ways of life and should replace them." Richard A. Shweder, Shouting at the Hebrews: Imperial Liberalism v. Liberal Pluralism and the Practice of Male Circumcision, 5 L., Culture \& Human. 247, 247 (2009). Consequently, if a group's practices are deemed to be inconsistent with liberalism by the majority, they would not be accommodated. $I d$. at 247. That is, sub-communities that reject the liberal commitments to individual autonomy, freedom, and a degree of social equality represent a threat to liberal ideals and to their predominance, and are consequently disfavored by liberal monists. See id. at 248 (asserting that liberal monists believe that practices they deem as "illiberal" should be disallowed in society). For these reasons, scholars whom we would characterize as liberal monists tend to see the ideal state as a secular liberal democracy that generally rejects religious accommodation when accommodation would be at odds with liberal commitments. Id. They would favor predominance of the central state over intermediate organizations with thick beliefs, including, but not limited to, religion. See generally Robert Audi, Moral Foundations of Liberal Democracy, Secular Reasons, and Liberal Neutrality Toward the Good, 19 NoTRE DAME J.L., ETHICS \& PUB. POL'Y 197 (2005) (explaining the normative foundations of a 
liberal democracy).

A related tenet that theoreticians of liberal democracy may espouse is that the state should vigorously protect a wide panoply of individual rights not only against government but also against non-state actors, including families. See generally James G. Dwyer, Parents' Religion and Children's Welfare: Debunking the Doctrine of Parents' Rights, 82 CALIF. L. REV. 1371 (1994) (proposing that children's rights, as opposed to parents' rights, should be the basis for protecting the legal interests of children, and that parents should be confined to having only child-rearing privileges, limited to actions that do not harm the child's interests). Thus, parents are said not to have rights with regard to their children. See generallyid. (arguing that children must be protected by the state from their parents); Vivian E. Hamilton, Immature Citizens and the State, 2010 B.Y.U. L. REV. 1055, 1078 (2010) (arguing that the state must protect the immature by not giving parents unchecked authority over them).

In contrast to liberal monists, liberal pluralists "make room for practices... whose moral foundations must be understood on more than, or other than, liberal terms," religious or not. Shweder, supra note 19, at 253. In other words, liberal pluralism, which roughly correlates with the "salad bowl" vision of social integration and diversity, accepts some practices that do not comport with a liberal worldview. See id. at 261 (noting that the logic of liberal pluralism leaves room for the toleration of illiberal practices and does not demand a moral judgment calling for the universal replacement of illiberal practices by liberal ones). There are two kinds of justifications for such liberal pluralism: idealist and pragmatic. See id.at 265 ("[A] balance must be struck between liberal and illiberal values to sustain any particular way of life."). Broadly speaking, idealist justifications suggest that pluralism is desirable, either in the abstract or in the particular circumstances of a given society, whereas pragmatic justifications suggest that regardless of whether pluralism is desirable, it may nevertheless be necessary for a state to achieve its larger goals. See id. ("[A]ny society that tried to keep everyone's options open everywhere and all the time would be following a recipe for producing chaos, frustration and endless failures of trust and cooperation among members of the same society...."). To be sure, it is not always clear which category a justification fits into, and some may have characteristics of both.

One clearly idealist justification for liberal pluralism asserts a principled commitment to diversity. William A. Galston, Two Concepts of Liberalism, 105 ETHICS 515, 523 (1995). As William Galston notes, "[L]iberalism is about the protection of diversity." Id. In this view, diversity itself is a valuable and desirable end, and even groups that espouse illiberal positions must be tolerated. Id. A related idea is that preserving rights of conscience serves as a bulwark against moral totalitarianism. See Chapman, supra note 17, at 1494-99 (arguing that protection of conscience's values promotes personal integrity and undermines the totalization of morality by the government). From a pragmatic standpoint, pluralism and accommodation may be necessary for the state to maintain its legitimacy, which is necessary for ensuring broad obedience of the law. See Tom R. Tyler, Psychological Perspectives on Legitimacy and Legitimation, 57 AnN. Rev. Psychol. 375, 376-77 (2006) (asserting that a State's legitimacy is largely dependent on the population's feelings toward its leaders and whether the people feel that the State leaders are entitled to rule). That is, if the State does not accommodate minority groups' practices and preferences, the 
legal assertions in this area are likely to have a tacit or explicit basis in political theory. In practical terms, the laws of a diverse democratic state must provide a compromise among individuals and groups with diverse viewpoints in this area, and we do not attempt to resolve the basic philosophical differences.

Rather, we are concerned with the narrower question of whether the law should provide special accommodations for practices that are motivated by religious conscience. That is, does religion have features entitling people who act out of sincere religious belief to receive special dispensation from the state under circumstances in which those who undertake similar actions for non-religious reasons would be punished? Here, too, the literature is rich. ${ }^{20}$ Proponents of religious accommodation

legitimacy of the State may corrode. See Jürgen Habermas, Between Facts AND Norms: Contributions to a Discourse Theory of LaW AND Democracy xxviii (William Rehg trans., 1988) ("[T] he law employed by the State ... must itself be legitimated through a broader discourse of citizens and their representatives."); see also Jonathan Jackson et al., Why Do People Comply with the Law? Legitimacy and the Influence of Legal Institutions, 52 BRIT. J. CRIMINOLOGY 1051, 1054 (2012) (arguing that citizens are more likely to obey State officials when they believe that the institution acts according to their shared moral purposes).

20. See, e.g., Christopher L. Eisgruber \& LaWrence G. SAger, Religious FREEDOM AND THE CONSTITUTION 50 (2007) (arguing for a neutral approach to religion); ANDREw Koppelman, DefEnding AmericAn REligious NeUtrality 1 (2013) (arguing for protection of both religion and conscience claims under the Free Exercise Clause); Brian Leiter, Why Tolerate Religion? 8 (2013) (arguing that religious claims of conscience should not be given preferential treatment to secular claims of conscience); Frederick Mark Gedicks, An Unfirm Foundation: The Regrettable Indefensibility of Religious Exemptions, 20 U. ARK. LiTTLE RocK L.J. 555, 572-74 (1998) (arguing that there are no plausible explanations supporting religious exemptions); Micah Schwartzman, What If Religion Is Not Special?, 79 U. CHI. L. REV. 1351, 1378 (2012) (arguing that religion deserves no special treatment from a moral perspective). But see Michael W. McConnell, Accommodation of Religion: An Update and a Response to the Critics, 60 GEO. WASH. L. REV. 685, 689-94 (1992) (arguing that religion is special and must be treated with more than formal neutrality); Michael W. McConnell, The Problem of Singling Out Religion, 50 DePaul L. REv. 1, 3 (2000) ("My thesis is that 'singling out religion' for special constitutional protection is fully consistent with our constitutional tradition.”); Michael Stokes Paulsen, God Is Great, Garvey Is Good: Making Sense of Religious Freedom, 72 NoTRE DAME L. REV. 1597, 1609 (1997) (reviewing John H. Garvey, What ARE FREEDOMS FOR? (1996)) (commenting that the core reason for religious liberty is that the founding generation singled out religion for special protection because of its intrinsic importance). 
argue that religion is indeed special. ${ }^{21}$ Micah Schwartzman has summarized their arguments as follows:

[T] he main normative argument for religious accommodation is based on the idea that religious believers have an inalienable right to pursue salvation according to the dictates of their consciences. The explicitly religious premise of this argument is that God, or some transcendent authority, has imposed duties on mankind and that fulfillment of those duties takes priority over complying with positive law .... To avoid infringing on [the duty to obey God], the state should minimize conflicts between legal and religious duties, which it can do partly by granting exemptions from laws that burden religious practices.

A second and related argument for religious accommodation is that when religious believers are forced to choose between their religious and legal duties, they experience greater suffering than nonbelievers faced with similar moral conflicts. Because believers affirm the existence of a transcendent authority and fear extratemporal punishments, they are anguished in ways that nonbelievers are not. ${ }^{22}$

On the other hand, opponents of religious accommodation argue "that privileging religious over secular claims violates a fundamental principle of neutrality," because in "singling out religion for special treatment, the government discriminates impermissibly against nonbelievers and sends a message that their views have an inferior status in the law." 23 Thus, for example, Eisgruber and Sager assert that the state is not obliged "to accept a religious believer's judgment about the importance of her religious interests as compared to the legitimate secular interests of the state." ${ }^{24}$ In this view, religious values and actions flowing from them should never be privileged over secular ones. ${ }^{25}$

21. See, e.g., Schwartzman, supra note 20, at 1365-66 (providing arguments and reasoning used by proponents of religious accommodation in support of the proposition that religion deserves accommodation in society).

22. Id.

23. Id. at 1374 .

24. Christopher L. Eisgruber \& Lawrence G. Sager, The Vulnerability of Conscience: The Constitutional Basis for Protecting Religious Conduct, $61 \mathrm{U}$. CHI. L. REV. 1245, 1286 (1994).

25. See id. ("[T]he deep interests of individuals figure into but do not override the secular concerns of the state ...."). 


\section{B. Accommodation vs. Non-Accommodation: Tracing the Supreme Court's Approach}

The First Amendment provides that "Congress shall make no law respecting an establishment of religion, or prohibiting the free exercise thereof." 26 The Supreme Court has vacillated in its understanding of what the latter guarantee, the Free Exercise Clause, requires in terms of religious accommodation. ${ }^{27}$ In its case of first impression, Reynolds $v$. United States, ${ }^{28}$ decided ninety years after the First Amendment was enacted, the Court held that the Free Exercise Clause does not require special accommodations for religious believers. ${ }^{29}$ Thus, the Reynolds Court held that states could enforce a statute criminalizing bigamy even against defendants whose bigamy was motivated by sincere religious beliefs. ${ }^{30}$

However, in its seminal 1963 decision in Sherbert v. Verner, ${ }^{31}$ the Court interpreted the Free Exercise Clause more robustly and announced that strict scrutiny would apply to any law that substantially_though incidentally-interfered with a person's religious beliefs or religiously-motivated conduct. ${ }^{32}$ Under this new rule, to interfere with religious practices, the government would have to articulate a compelling interest and demonstrate that there was no less intrusive means of achieving the state's interest. ${ }^{33}$

26. U.S. CONST. amend. I.

27. See, e.g., Reynolds v. United States, 98 U.S. 145, 166-68 (1878) (concluding that the Free Exercise Clause does not require special accommodations for religious believers); Sherbert v. Verner, 374 U.S. 398, 40203 (1963) (finding that government may not infringe upon religious beliefs without a compelling purpose).

28. 98 U.S. 145 (1878).

29. See id. at 167 (reasoning that to "permit this [religious exemption] would be to make the professed doctrines of religious belief superior to the law of the land, and in effect to permit every citizen to become a law unto himself. Government could exist only in name under such circumstances").

30. See id. (concluding that a person cannot be excused from committing a crime simply because he does so in the name of religion).

31. 374 U.S. 398 (1963).

32. See id. at 402 ("The door of the Free Exercise Clause stands tightly closed against any governmental regulation of religious beliefs . . ..”).

33. See id. at 403 (noting that the government may regulate if certain religious beliefs or practices pose a substantial threat to public safety, peace, or 
Subsequent opinions eroded the Court's commitment to strict scrutiny. ${ }^{34}$ In Goldman $v$. Weinberger ${ }^{35}$ the Court rejected the application of strict scrutiny in the military context, where the plaintiff argued that the military's dress policy interfered with his right to wear a yarmulke on his head. ${ }^{36}$ In O'Lone $v$. Estate of Shabazz, ${ }^{37}$ the Court ruled that strict scrutiny also did not apply in the prison context. ${ }^{38}$ Cases involving American Indians, including Bowen v. Roy ${ }^{39}$ and Lyng v. Northwest Indian Cemetery Protective Ass'n, ${ }^{40}$ further weakened the strict scrutiny regime. ${ }^{41}$ To be sure, the Supreme Court frequently carves out denials to servicemen and prisoners that it permits to other citizens on the grounds that servicemen have waived and prisoners have forfeited some of their liberties; ${ }^{42}$ and cases involving American Indians may also be seen as unique, as the rights claimed by

order).

34. See, e.g., Goldman v. Weinberger, 475 U.S. 503, 509-10 (1986) (concluding that the First Amendment does not require the military to accommodate certain religiously held practices if it would not be in the military's best interest); O'Lone v. Estate of Shabazz, 482 U.S. 342, 353 (1987) (reasoning that the First Amendment does not prevent prisons from exercising their best judgment in running a prison).

35. 475 U.S. 503 (1986).

36. See id. at 509-10 ("[T]he First Amendment does not require the military to accommodate such practices in the face of its view that they would detract from the uniformity sought by the dress regulations.").

37. 482 U.S. 342 (1987).

38. See id. at 353 ("[C]oncerns of prison administrators provide adequate support for the conclusion that accommodations of respondents' request to attend Jumu'ah would have undesirable results in the institution. These difficulties also make clear that there are no obvious, easy alternatives to the policy adopted by petitioners.").

39. 476 U.S. 693 (1986).

40. 485 U.S. 439 (1988).

41. See Bowen, 476 U.S. at 695-98 (requiring appellants to obtain a Social Security card for their daughter even though appellants claim it violates their Native American religious beliefs); Lyng, 485 U.S. at 441-42 (finding that the First Amendment did not preclude appellants from completing a road or from permitting timber harvesting on Indian religious grounds because those religious practices must yield to higher consideration).

42. See, e.g., Goldman v. Weinberger, 475 U.S. 503, 525 (1986) ("Except as otherwise required by 'interests of the highest order,' soldiers as well as civilians are entitled to follow the dictates of their faiths."); O'Lone, 482 U.S. at 348 (citing cases that note that lawfully imprisoned individuals give up at least some constitutional rights). 
American Indians have a political component as well as a religious component because of treaties that Indian tribes signed ceding some, but not all, of their sovereignty to the federal government. ${ }^{4} 3$

Eventually, in 1990, the Court reversed Sherbert and rolled back strict scrutiny for all persons under its jurisdiction in its opinion in Employment Division v. Smith. ${ }^{44}$ Smith had argued that he should not be fired from his job for ingesting peyote, a hallucination-inducing drug, as part of a religious ceremony. ${ }^{45} \mathrm{In}$ rejecting this claim, the Court promulgated a new standard, holding that the Constitution does not require strict scrutiny of general laws with secular intent that are neutrally applied and that only incidentally interfere with religious practices. ${ }^{46}$ Because the prohibition on peyote was neutrally applied to all, and was neither intended to burden nor applied to discriminate against religious users, it was presumptively valid; the Free Exercise Clause did not protect Smith. ${ }^{47}$

The Court has continued to adhere to Smith's general rule but has refined it. ${ }^{48}$ In Church of the Lukumi Babalu Aye, Inc. $v$.

43. See, e.g., Philip J. Prygoski, From Marshall to Marshall: The Supreme Court's Changing Stance on Tribal Sovereignty, AM. BAR ASS'N (1995), http://www.americanbar.org/newsletter/publications/gp_solo_magazine_home/gp _solo_magazine_index/marshall.html (last visited Jan. 30, 2016) (discussing the effects of treaties between the United States and Native American tribes on tribal sovereignty) (on file with the Washington and Lee Law Review).

44. See Emp't Div. v. Smith 494 U.S. 872, 886-87 (1990) ("It is no more appropriate for judges to determine the centrality of religious beliefs before applying a compelling interest test in the free exercise field, than it would be for them to determine the importance of ideas before applying the compelling interest test in the free speech field.").

45. Id. at 874 .

46. See id. at 892 ("The Court today extracts from our long history of free exercise precedents the single categorical rule that if prohibiting the exercise of religion .... is ... merely the incidental effect of a generally applicable and otherwise valid provision, the First Amendment has not been offended.").

47. See id. at 879 ("Subsequent decisions have consistently held that the right of free exercise does not relieve an individual of the obligation to comply with a valid and neutral law of general applicability on the ground that the law proscribes (or prescribes) conduct that his religion prescribes (or proscribes).”).

48. See Church of the Lukumi Babalu Aye, Inc. v. City of Hialeah, 508 U.S. 520, 531-32 (1993) (striking down an ordinance that was not neutral or generally applicable and did not contain a compelling government interest). 
City of Hialeah, ${ }^{49}$ the Court struck down a local ordinance that interfered with animal sacrifice by members of the Santeria religion. ${ }^{50}$ The Court reasoned that the ordinance in question, though perhaps facially neutral, was not neutral in effect because it had been deliberately crafted to target a religious practice. ${ }^{51}$ Most recently, in Hosanna-Tabor $v$. EEOC, ${ }^{52}$ the Court incorporated a ministerial exception into its Free Exercise doctrine, holding that anti-discrimination laws, though neutral and generally applicable, could not apply to restrict a religious organization's decisions concerning employment of its ministers, defined as "those who will personify [a church's] beliefs." 53

This is essentially where constitutional doctrine stands today. Truly neutral laws of general applicability do not violate the Free Exercise Clause and are presumptively valid, except in the context of religious organizations' ministerial employment decisions, and perhaps their internal regulations and behavior more broadly. ${ }^{54}$

\section{Beyond Philosophy and Constitutionalism: Accommodationism Today}

In navigating between the poles of accommodation and non-accommodation, all modern liberal societies have staked out middle grounds, seeking to balance the interests on both sides. American politics have generally produced a more accommodationist stance than those adopted by some other

49. 508 U.S. 520 (1993).

50. Id. at 547 .

51. See id. at 534 ("Official action that targets religious conduct for distinctive treatment cannot be shielded by mere compliance with the requirement of facial neutrality. The Free Exercise Clause protects against governmental hostility which is masked as well as overt.").

52. 132 S. Ct. 694 (2012).

53. Id. at 697 .

54. See id. at 702 (allowing religious groups to shape their own faith and mission through its ministerial appointments); Emp't Div. v. Smith, 494 U.S. 872 (1990) (concluding that neutral and generally applicable laws do not violate the Free Exercise Clause). 
liberal democracies even though this has not been required since Smith.55

For example, Scandinavian attitudes tend to lean toward non-accommodation, as expressed in the compulsory education requirements in Finland, ${ }^{56}$ Denmark bans on both the Jewish and Islamic ritual slaughter of animals on the grounds that "animal rights come before religion," 57 and Danish and Swedish medical associations' recommendation to ban ritual male infant circumcision, though the governments of these countries have not banned circumcision currently. ${ }^{58}$ France has banned religious clothing-veils, turbans, yarmulkes, hijabs, and so on-from the public classroom and has outlawed veils that cover one's face in most public places. ${ }^{59}$ Scandinavian countries come to non-accommodation of minority religions in part from their tradition in Christianity, whereas France has a long history of

55. See Smith, 494 U.S. at 872 (finding that a law prohibiting the ingestion of peyote was neutral, generally applicable - not targeting any specific religionand therefore valid).

56. See Peter Wilby, Finland's Education Ambassador Spreads the Word, The GUARDIAN (July 1, 2013), http://www.theguardian.com/ education/2013/jul/ 01/education-michael-gove-finland-gcse (last visited Jan. 16, 2016) (explaining Finland's education system, including the requirement that children attend school from the age of seven to sixteen) (on file with the Washington and Lee Law Review).

57. Adam Withnall, Denmark Bans Kosher and Halal Slaughter as Minister Says 'Animal Rights Come Before Religion', THE InDEP. (Feb. 18, 2014), http://www.independent.co.uk/news/world/europe/denmark-bans-halal-andkosher-slaughter-as-minister-says-animal-rights-come-before-religion-

9135580.html (last visited Jan. 16, 2016) (on file with the Washington and Lee Law Review).

58. See Lydia Smith, Sweden and Denmark Recommend Ban on Non-Medical Circumcision of Boys, InT'L Bus. Times (Jan. 29, 2014), http://www.ibtimes.co.uk/sweden-denmark-recommend-ban-non-medicalcircumcision-boys-1434354 (last visited Jan. 16, 2016) ("In Denmark, the Danish College of General Practitioners penned a statement that denounced circumcision was akin to abuse and mutilation. In a poll undertaken by the newspaper BT, it was revealed that $87 \%$ were in favour of a ban on the procedure.") (on file with the Washington and Lee Law Review).

59. See Elaine Ganely, French School Bans Muslim Girl from Wearing Long Skirt, Prompting Twitter Backlash, Huffington Post (Apr. 29, 2015), http://www.huffingtonpost.com/2015/04/29/french-muslim-skirt-

ban_n_7170140.html (last visited Jan. 16, 2016) (explaining why a girl was banned from class for wearing religious clothing) (on file with the Washington and Lee Law Review). 
freedom of religious belief combined with exclusion of religion from the public sphere. ${ }^{60}$

In contrast, the United States seems to lean more toward accommodationism even in the absence of any constitutional obligation. ${ }^{61}$ Lupu and Tuttle have observed that "[r]eligious activity and pluralism in the United States far outstrip that of any other Western nation, yet religious strife has played no significant part in our history." 62 Our anti-totalitarian country is one of hyphenated identities, multiculturalist and tolerant ethos, and individualist self-conception. ${ }^{63}$ This pluralist impulse extends beyond just religious accommodationism, though it is perhaps most evident and pronounced in that context. 64

Our accommodationist tendencies may arise from political and cultural attitudes and discourse that date back to our country's founding ideals and immigrant history. ${ }^{65}$ As George Washington wrote to the Jewish community of Newport, Rhode Island, "the United States, which gives to bigotry no sanction, to persecution no assistance, requires only that they who live under its protection should demean themselves as good citizens." 66

60. See Andrew M. Greeley, Religious Decline in Europe?, AM. NAT'L CATHOlic Rev. (Mar. 1, 2004), http://americamagazine.org/issue/475/ article/religious-decline-europe (last visited Jan. 16, 2016) (stating that religion in France is declining, while there are high rates of atheism and nonaffiliation) (on file with the Washington and Lee Law Review).

61. See generally Levin, Rethinking Religious Minorities, supra note 1, at 1617 (addressing the surprising degree of religious accommodation adopted by elected officials).

62. Ira C. Lupu \& Robert Tuttle, The Distinctive Place of Religious Entities in Our Constitutional Order, 47 VILL. L. REV. 37, 39 (2002).

63. See Levin, Rethinking Religious Minorities, supra note 1, at 1660 (suggesting that religious tolerance is "deeply embedded in our collective identity").

64. See id. (positing that Americans' customs involving religious accommodation spill over into other areas of life).

65. See id. (discussing American history and self-identity).

66. Letter from George Washington to Touro Synagogue (1790), AM. TREASURES OF THE LIB. OF CONGRESS, https:/www.loc.gov/exhibits/treasures/ trm006.html (last visited Apr. 20, 2016) (on file with the Washington and Lee Law Review). This, of course, begs the question of what is a good citizen. Requiring more of a good citizen than generally obeying the laws and not knowingly working against the interests of the nation would exclude many people who are not ordinarily thought of as bad citizens, but who are simply indifferent to public affairs. Using as minimal a test as bothering to vote would still exclude many people from the ranks of good citizens. See Lawrence Ezrow 
As we will demonstrate, the structure of our government and the nature of interest group politics also contribute to this tolerant and accommodationist dynamic. ${ }^{67}$ All of that said, this general embrace of pluralism is hardly complete or consistent. ${ }^{6}$

\section{Constitutional Expressions of Accommodationism and Their Limits}

Those parts of the Bill of Rights that most clearly reflect the accommodationist mindset include the First Amendment's Establishment Clause, ${ }^{69}$ Free Exercise Clause, ${ }^{70}$ and Free Speech Clause. ${ }^{71}$ Each of these stands, at least, for two propositions: That individuals cannot be compelled to conform to a particular religious or secular viewpoint, and that they retain sufficient autonomy to reject the beliefs and values of the majority or of the government itself. ${ }^{72}$

\& Georgios Xezonakis, Satisfaction with Democracy and Voter Turnout: A Temporal Perspective, PARTY POL. 1, 3 (2014), http://privatewww.essex. ac.uk/ ezrow/publications/Satisfaction\%20with\%20Democracy\%20and\%20Voter\% 20Turnout.pdf (documenting that voter turnout in twelve democracies in Western and Southern Europe from 1976 to 2011, and ranging from 60\% to $85 \%)$; see also Voting and Registration in the Election of November 2012Detailed Tables, U.S. CENSUS BUREAU (2012), http://www.census.gov/ hhes/www/socdemo/voting/publications/p20/2012/tables.html (last updated May 8, 2013) (last visited Jan. 16, 2016) (documenting that fewer than $65 \%$ of eligible Americans in the United States voted in the most recent presidential election) (on file with the Washington and Lee Law Review).

67. See Levin, Rethinking Religious Minorities, supra note 1, at 1657 ("[The United States] is among the most religiously tolerant and accommodating country in the world, with religious minority groups enjoying overwhelming liberty, thanks largely to the beneficence of the majoritarian branches of government.").

68. See infra Part II.C.1 (discussing the road blocks the First Amendment places on state and federal government action in the interest of preserving freedom of speech and religion).

69. See U.S. Const. amend. I (prohibiting Congress from making any law "respecting an establishment of religion").

70. See id. (denying Congress the power to prohibit the free exercise of religion).

71. See id. ("Congress shall make no law... abridging the freedom of speech, or of the press ....”).

72. The consistent overruling of government action even where governmental interests would appear to be strong demonstrates the high value placed on such propositions. See infra notes 75-89 and accompanying text 
Education law offers an illuminating example of the embrace of religious exercise and individualist expression. ${ }^{73}$ Schooling is one of the few widely shared experiences in our society and is, to boot, a formative experience for future participants in our political and social culture. Enormous resources are devoted to our public schools, ${ }^{74}$ in part because an educated citizenry is widely considered fundamental to the viability of our national project. ${ }^{75}$ If ever the state had an interest in conformity and enforced participation in its pursuit of the public good, compulsory public education with a common curriculum would be a superb expression of this interest. ${ }^{76}$

Yet the Supreme Court has read the Speech and Religion Clauses to drastically constrain the ability of the state to inculcate even the most basic civic values when doing so conflicts with parents' religious or philosophical commitments and affiliations. For instance, the state is prohibited from mandating attendance at public schools, ${ }^{77}$ from restricting the subjects that may be taught to children, ${ }^{78}$ from limiting even information

(comparing cases in which the government survived and failed First Amendment challenges).

73. See infra notes 77-87 and accompanying text (citing cases rulingfairly consistently-in favor of freedom of religion and speech, except where plaintiffs failed to establish an actual burden or the state action was neutral with respect to religion).

74. See generally Mildred Wigfall Robinson, Financing Adequate Educational Opportunity, 14 J.L. \& PoL. 483 (1998) (discussing the amount of resources poured into public education but lamenting the discrepancies in funding across public schools).

75. See id. at 484 ("[Education] is required in the performance of our most basic responsibilities .... It is the very foundation of good citizenship." (quoting Brown v. Bd. of Educ., 347 U.S. 483, 493 (1954))).

76. See infra notes 77-81 and accompanying text (discussing mandatory public school attendance laws).

77. See Wisconsin v. Yoder, 406 U.S. 205, 234 (1972) (finding Wisconsin's compulsory school attendance law to unduly burden defendant's rights under the Free Exercise Clause). While Wisconsin did have an interest in ensuring that children are "self-reliant and self-sufficient" members of society, the Court found that the additional two years mandated by the law "would do little to serve those interests." Id. at 221-22.

78. See Edwards v. Aguillard, 482 U.S. 578, 585 (1987) (finding Louisiana's Creationism Act-forbidding the teaching of the theory of evolution without also teaching "creation science"-violative of the Establishment Clause because it lacked a "clear secular purpose"). 
deemed transgressive that is available to students, ${ }^{79}$ or from demanding expressions of fealty and allegiance to the government. ${ }^{80}$ Parents are allowed to send their children to non-government schools, ${ }^{81}$ and the state may even provide cash vouchers $^{82}$ and tax deductions for private school-including religious school-tuition. ${ }^{83}$

More generally, although the precise contours of the Constitution's speech and religion guarantees are subject to contention, all would at least agree with the fundamental proposition that the government is constitutionally barred from imposing on its citizens any single ideological vision, religious or secular. ${ }^{84}$ Thus, the courts have been clear that the guarantee of freedom of speech protects expression of even the most marginalized and disagreeable ideas. ${ }^{85}$ If a public institution

79. See Bd. of Educ. v. Pico, 457 U.S. 853, 868 (1982) (finding the Board of Education's rejection of books it deemed "anti-Christian," "anti-American," etc. violative of the First Amendment).

80. See W. Va. State Bd. of Educ. v. Barnette, 319 U.S. 624, 642 (1943) (invalidating a state statute mandating students to salute the American flag in school). The plaintiffs' religion forbade worshipping a symbol-in the present case, the American flag. Id. Therefore, by mandating the salute, the law violated the First Amendment by compelling plaintiffs to act against their faith. Id. But see Mozert v. Hawkins Cty. Bd. of Educ., 827 F.2d 1058, 1068 (6th Cir. 1987) (upholding the use of certain textbooks in school because plaintiffs failed to show that reading the textbooks posed an actual burden on their free exercise of religion).

81. Compare Pierce v. Soc'y of Sisters, 268 U.S. 510, 534-36 (1925) (declaring an Oregon statute-requiring public school attendance and forbidding private school attendance-unconstitutional), with Jonathan L. v. Superior Court, 165 Cal. App. 4th 1074, 1101 (2008) (declaring that there is no absolute constitutional right to home school one's children), and El Paso Indep. Sch. Dist. v. McIntyre, 457 S.W.3d 475, 499 (Tex. App. 2014) (same).

82. See Zelman v. Simmons-Harris, 536 U.S. 639, 653-54 (2002) (finding a state plan subsidizing private school tuition neutral with respect to religion because aid was granted based on secular criteria).

83. See Mueller v. Allen, 463 U.S. 388, 390-91 (1983) (validating a state law granting deductions for expenditures on school supplies that predominantly benefitted parents of children attending parochial schools).

84. See Barnette, 319 U.S. at 642 (" $[\mathrm{N}]$ o official, high or petty, can prescribe what shall be orthodox in politics, nationalism, religion, or other matters of opinion or force citizens to confess by word or act their faith therein.").

85. See Brown v. Entm't Merchs. Ass'n, 131 S. Ct. 2729, 2733 (2011) (declaring a California statute banning the rental of violent video games to minors unconstitutional and noting that video games qualify for First Amendment protection); United States v. Stevens, 559 U.S. 460, 482 (2010) 
chooses to rent its facilities to private groups, it is prohibited from excluding religious groups or groups with disfavored views from the opportunity to rent the facilities. ${ }^{86}$ If a legislative body chooses to permit a religious invocation during proceedings, it may not select speakers based on the degree to which their beliefs or expressions comport with the state's own values. ${ }^{87}$ If a religious display is erected on public property, it will only be upheld as constitutional if enough secular or competing religious symbols are included to make clear to the viewer that the message being conveyed is one of pluralism. ${ }^{88}$ Religious non-profit organizations, as well as intimate and expressive associational groups, generally are not subject to anti-discrimination laws that interfere with their own core values and autonomy. ${ }^{89}$ And under our Constitution, there are no officially recognized religious

(invalidating a federal law aimed to illegalize the distribution of depictions of animal cruelty); Ashcroft v. Free Speech Coal., 535 U.S. 234, 258 (2002) (finding a portion of a statute banning the production of virtual child pornography unconstitutional because the material was neither obscene nor "intrinsically related' to the sexual abuse of children" (citing New York v. Ferber, 458 U.S. 747, 759 (1982))); Snyder v. Phelps, 580 F.3d 206, 226 (4th Cir. 2009) (allowing an anti-homosexual demonstration near a service member's funeral); Robb v. Hungerbeeler, 370 F.3d 735, 745 (8th Cir. 2004) (stating that the regulation that prevented the $\mathrm{Ku}$ Klux Klan from adopting a highway was unconstitutional); Collin v. Smith, 578 F.2d 1197, 1210 (7th Cir. 1978) (invalidating prohibitions that prevented Nazi demonstrations). But see generally Holder v. Humanitarian Law Project, 561 U.S. 1 (2010) (upholding a statute banning material support to designated terrorist organizations). In Humanitarian Law Project, instructing terrorist group members how to use the law to settle disputes was considered "material support;" and the Court therefore found that the statute was not unconstitutional as applied. Id. at 25-28.

86. See Widmar v. Vincent, 454 U.S. 263, 277 (1981) (holding that a school that created a forum open to student groups could not exclude religious groups from using the facilities).

87. See Marsh v. Chambers, 463 U.S. 783, 794-95 (1983) (holding that Nebraska's practice of opening its legislative sessions with a prayer was not a violation of the Establishment Clause because "there is no indication that the prayer opportunity has been exploited to proselytize or advance any one, or to disparage any other, faith or belief").

88. See Lynch v. Donnelly, 465 U.S. 668, 685 (1984) (allowing a city to display a crèche because it also has a secular purpose).

89. See Corp. of Presiding Bishop of the Church of Jesus Christ of Latter-Day Saints v. Amos, 483 U.S. 327, 338-40 (1987) (holding that a religious exemption to the prohibition against religious discrimination in employment does not violate the Establishment Clause because religious organizations have an interest in autonomy in selecting their leaders and employees). 
spokespeople or representatives. ${ }^{90}$ Each person is entitled to her own religious views and commitments, however idiosyncratic, and is thus entitled to the same religious freedoms as anyone else. ${ }^{91}$

Beyond the First Amendment, other constitutional guarantees also resonate with a broadly tolerant approach. Lawrence $v$. Texas ${ }^{92}$ held that under the Due Process Clause, the state may not legislate on the basis of morality alone. ${ }^{93}$ The Due Process Clause and other constitutional provisions have been held to fundamentally guarantee a measure of bodily and sexual autonomy, privacy, and the right to parent one's children. ${ }^{94}$ These rights reinforce the limits of the state's ability to impose the majority's moral values on the minority. ${ }^{95}$

Even the Constitution's basic structural elements protect dissenters. Our federalist structure allows different states to preserve their different characters. ${ }^{96}$ State constitutions and statutes further devolve governmental authority to municipalities, counties, and local school boards. ${ }^{97}$ Thus,

90. This is likely the result of the Constitution's Establishment Clause. U.S. CONST. amend. I.

91. See id. (prohibiting any law dealing with the establishment of religion).

92. 539 U.S. 558 (2003).

93. See id. at 578-79 ("The State cannot demean [petitioners'] existence or control their destiny by making their private sexual conduct a crime.").

94. See id. at 573-74 (stating that the laws give protection to "decisions relating to marriage, procreation, contraception, family relationships, child rearing, and education" (citing Planned Parenthood of Se. Pa. v. Casey, 505 U.S. 833, 851 (1992))); see also Meyer v. Nebraska, 262 U.S. 390, 403 (1923) (finding a statute outlawing teachers from teaching students languages other than English "arbitrary and without reasonable relation to any end within the competency of the State").

95. This proposition is best exemplified by Lawrence. See Lawrence, 539 U.S. at 582 (finding that "moral disapproval is [not] a legitimate state interest to justify by itself a statute that bans homosexual sodomy, but not heterosexual sodomy").

96. See William G. Buss, Essay, An Essay on Federalism, Separation of Powers, and the Demise of the Religious Freedom Restoration Act, 83 IowA L. REV. 391, 396 (1998) ("A most elementary principle of American constitutional law is that the United States Constitution creates a 'federal system,' under which sovereign power is divided between the national government and state governments." (citation omitted)).

97. See GA. Const. art. IX, §2, paras. I-II (giving legislative power to counties and cities). 
returning to the education law context, it would be exceedingly difficult for the federal government to impose any uniform curriculum or character on the public school system. ${ }^{98}$ Additionally, the counter-majoritarian structural features of the federal government-small states enjoy equal representation in the Senate ${ }^{99}$ and overrepresentation in the Electoral College's vote for President ${ }^{100}$ _and the requirements of bicameralism and presentment ${ }^{101}$ together make it difficult for the government to pass laws over strong minority opposition. This further works to protect minorities and dissenters-religious and otherwise-from having a monist vision imposed upon them.

To be sure, the constitutional embrace of tolerance, pluralism, diversity, and accommodationism is not absolute, nor can it be. ${ }^{102}$ Unfettered, it would result in chaos and anarchism, as each individual or group would be left free to follow its own will and practices, unrestrained by any governmental authority. ${ }^{103}$ Law and organized society would be impossible in the face of unbridled pluralism; courts have struggled to balance the promise of individual freedom against the needs for law and order, the equal application of law to all groups, and the protection of individuals throughout society. ${ }^{104}$ This has proven

98. See generally Jacob T. Levy, Rationalism, Pluralism, And Freedom (2014) (comparing and contrasting the tensions between the state and intermediate groups such as religious groups and universities).

99. U.S. Const. art. I, § 3, cl. 1.

100. Id. art. II, $\S 1$, cl. 2 .

101. Id. art. I, $\S 7$, cls. $2-3$.

102. Content-based restrictions on speech are perfect examples of such logical limitations. See, e.g., Chaplinsky v. New Hampshire, 315 U.S. 568, 573 (1942) (affording no First Amendment protection to "fighting words"); Schenck v. United States, 249 U.S. 47, 52 (1919) ("The most stringent protection of free speech would not protect a man in falsely shouting fire in a theatre and causing a panic."); New York v. Ferber, 458 U.S. 747, 765 (1982) (excluding child pornography from First Amendment protection).

103. See Emp't Div. v. Smith, 494 U.S. 872, 888 (1990) (stating that every regulation of conduct that does not protect a religious interest cannot be presumptively invalid because it "would be courting anarchy").

104. For example, courts have attempted to address these issues with varying levels of scrutiny analyses in the Equal Protection context. See Clark v. Jeter, 486 U.S. 456, 461 (1988) ("At minimum, a statutory classification must be rationally related to a legitimate governmental purpose. Classifications based on race or national origin, and classifications affecting fundamental rights are given [strict] scrutiny .... [I]ntermediate scrutiny ... applie[s] to discriminatory 
even more elusive in the context of the state's relationship with religion. ${ }^{105}$

For example, in Locke v. Davey, ${ }^{106}$ the Court held that a state is permitted to exclude students studying religion from a scholarship program that supported all other courses of study. ${ }^{107}$ This seems to reflect the relatively non-accommodationist viewpoint that laws may favor the study of secular subjects over that of religious subjects. Even more significantly, in Christian Legal Society Chapter of the University of California $v$. Martinez, ${ }^{108}$ the Court held that a state university could condition its support for a student group on its willingness to allow all students to participate equally in the group's activities and governance, even where doing so would conflict with a group's religious or expressive viewpoint. 109 This, too, expressed a non-accommodationist approach, for it allows the state to privilege its own vision of inclusivity over a religious or expressive group's preference for exclusivity, even to the extent of allowing public universities to require as a condition for recognition that religious organizations admit members who do not belong to the religion to whose purposes the group is dedicated. And, as we have already seen, in some cases even before Employment Division $v$. Smith, when strict scrutiny purportedly applied to laws that conflicted with minority religious practices, the Court nonetheless upheld the government policy. ${ }^{110}$ Finally, in its decision in Smith, the Court struck a

classifications based on sex or illegitimacy.”).

105. See supra notes 77-87 and accompanying text (citing cases that discuss freedom of religion).

106. 540 U.S. 712 (2004).

107. See id. at 725 ("Given the historic and substantial state interest [against the establishment of religion] at issue, it cannot be concluded that the denial of funding for vocational religious instruction alone is inherently constitutionally suspect.").

108. 561 U.S. 661 (2010).

109. See id. at 698 (allowing a state university to require that a Christian group allow non-Christians the opportunity for full participation as a condition for university financial support).

110. See supra notes 106-109 and accompanying text (finding alleged encumbrances on the exercise of religion valid in limited public forums-where the institution's policies are reasonable and viewpoint neutral-as well as in distribution of scholarship aid); see also United States v. Lee, 455 U.S. 252, 254 (1982) (upholding the constitutionality of mandatory social security taxes even 
powerful blow against constitutionally guaranteed religious accommodationism, holding that lawmakers need not specially accommodate religious groups under the Free Exercise Clause as long as the law is neutral and generally applicable. ${ }^{111}$ Such laws thus are presumptively valid despite their intrusion on a person's ability to live in accordance with her own religious practices. ${ }^{112}$

In short, a greater degree of tolerance, minority protection, and religious accommodationism is embedded in the American constitutional framework than in those of some other Western democracies, but the Court's commitment to such a reading of the Constitution has hardly been absolute or consistent.

\section{Statutory Expressions of Accommodationism and Their Limits}

The majoritarian branches of government have gone far beyond what the Supreme Court has required in accommodating religious freedom. ${ }^{113}$ For instance, the Tax Code gives favorable treatment to religious organizations, whether or not they share the majority's values. ${ }^{114}$ From the time of the founding, Congress has allowed conscientious objectors to refuse to be drafted into the military, determining that even when it comes to society's basic need to provide for its own protection, dissenting groups

when it violated the Amish taxpayer's religion).

111. See Emp't Div. v. Smith, 494 U.S. 872, 887 (1990) (finding that the Free Exercise Clause permits a state to deny unemployment benefits to a person discharged for drug use-even if the drug is used for religious purposes-if it is a valid and neutral law of general applicability).

112. See id. at 888 ("[W]e cannot afford the luxury of deeming presumptively invalid, as applied to the religious objector, every regulation of conduct that does not protect an interest of the highest order.").

113. See Levin, Rethinking Religious Minorities, supra note 1, at 1642-56 (discussing the interplay between the legislative and judiciary branches in accommodating, as well as hindering, religious freedom); see also James E. Ryan, Note, Smith and the Religious Freedom Restoration Act: An Iconoclastic Assessment, 78 VA. L. REV. 1407, 1445-46 (1992) (finding that there were over 2,000 religious exemptions to generally applicable laws and stating that the political process was protective of religious freedom).

114. See id. at 1456 ("The tax laws contain numerous exemptions for religious groups and allow deductions for contributions to religious organizations."). But see Bob Jones Univ. v. United States, 461 U.S. 574, 598-99 (1983) (holding that a racially discriminatory private school may not enjoy tax exemptions). 
should not be compelled to violate their religious or philosophical worldviews. ${ }^{115}$

More recently, federal and state legislatures have provided similar conscience clauses to allow medical professionals to decline to perform sterilization or pregnancy termination procedures or even to prescribe contraceptives on the basis of their religious beliefs. ${ }^{116}$ Similarly, states may require vaccination of children, but all but three have religious or philosophical exemptions to vaccination requirements. ${ }^{117}$ Such exemptions put children at risk and have the potential to contribute to epidemics outside the community that refuses vaccination. ${ }^{118}$

115. See Paul M. Landskroener, Note, Not the Smallest Grain of Incense: Free Exercise and Conscientious Objection to Draft Registration, 25 VAL. U. L. REV. 455, 455 (1991) (noting that draft exemptions for conscious objectors in the United States have existed since colonial times).

116. See 42 U.S.C. $§ 238 n(2012)$

The Federal Government, and any State or local government that receives Federal financial assistance, may not subject any health care entity to discrimination on the basis that... (1) the entity refuses to undergo training in the performance of induced abortions, to require or provide such training, to perform such abortions . . . .

42 U.S.C. $§ 300$ a-7 ("Prohibition of public officials and public authorities from imposition of certain requirements contrary to religious beliefs or moral convictions [with regard to abortions or sterilization] ...."); Levin, Rethinking Religious Minorities, supra note 1, at 1650 (discussing state and federal statutes allowing medical professionals to refuse to provide care related to abortion or sterilization).

117. See Vaccine Laws, NAT'L VACcine INFO. CTR., http://www.nvic.org/vaccine-laws.aspx (last visited Jan. 19, 2016) (listing West Virginia and Mississippi as the only states that do not provide a religious exemption to vaccination) (on file with the Washington and Lee Law Review).

118. See Allan J. Jacobs, Needles and Notebooks: The Limits of Requiring Immunization for School Attendance, 33 HAMLINE L. REV. 171, 175-77 (2010) (providing the scientific reasoning for vaccination). See also generally Amy A. Parker et al., Implications of a 2005 Measles Outbreak in Indiana for Sustained Elimination of Measles in the United States, 355 NEW ENG. J. MED. 447 (2006) (discussing the vaccination of measles and its effects). At the time these Articles were published, only Mississippi and West Virginia had no non-medical exemptions; California recently enacted a statute, SB277, requiring full immunization as a condition for a child to attend a school or child care facility, with only medical exemptions permitted. See Michelle M. Mello, David M. Studdert \& Wendy E. Parmet, Shifting Vaccination Politics-The End of Personal-Belief Exemptions in California, 373 NEw ENG. J. MED. 785, 785-87 (2015) (discussing California's tighter policy on mandatory vaccinations in light of SB277's passage). 
Reflecting a similarly accommodationist approach, all states allow parents to homeschool their children, though there may be good reasons to limit homeschooling. ${ }^{119}$ The Supreme Court has never interpreted the Constitution to require such accommodation, which may constrain a child's options in life and interfere with society's interest in developing a uniformly educated and acculturated citizenry. ${ }^{120}$ Nevertheless, all states give parents the right to homeschool their children. ${ }^{121}$

Likewise, Congress-not the Court-acted to ensure that religious service members would be permitted to wear religious symbols. ${ }^{122}$ Indeed, in a variety of areas, Congress, state legislatures, and administrative agencies have gone well beyond what the Court has required in accommodating the unique needs of diverse religious minority groups, such as Native Americans, Amish, and Orthodox Jews. ${ }^{123}$ There are thousands of statutory provisions-and many more administrative and local policiesthat protect and assist religious minority groups by granting them special treatment and accommodations, further reflecting a broadly pluralist viewpoint-at least, legislatively. ${ }^{124}$

Most important, after the Supreme Court rolled back protections of religious groups' practices in its Smith decisionfinding that religious groups are not constitutionally entitled to legislative accommodation ${ }^{125}$ —Congress responded by enacting

119. See McMullen, supra note 8, at 83 (noting that homeschooling may stunt the development of social skills in children).

120. See supra note 81 and accompanying text (comparing cases discussing mandatory public school attendance laws and homeschooling issues).

121. See State Laws, HSLDA, https://www.hslda.org/laws/ (last visited Jan. 19, 2016) (providing a map of the United States, color coding states in accordance with varying levels of homeschooling regulation) (on file with the Washington and Lee Law Review).

122. See 10 U.S.C. $§ 774$ (2012) ("[A] member of the armed forces may wear an item of religious apparel while wearing the uniform of the member's armed force.").

123. See Levin, Rethinking Religious Minorities, supra note 1, at 1647 (discussing Congress's response to different Supreme Court cases involving religious exceptions for Native Americans, Amish, and Orthodox Jews).

124. See id. (identifying the legislature as the driving accommodationist force behind religious freedom).

125. See Emp't Div. v. Smith, 494 U.S. 872, 890 (1990) (“[T]o say that a nondiscriminatory religious-practice exemption is permitted, or even that it is desirable, is not to say that it is constitutionally required ...."). 
(with near unanimity) the Religious Freedom Restoration Act (RFRA) ${ }^{126}$ and subsequently, the Religious Land Use and Institutionalized Persons Act (RLUIPA). ${ }^{127}$ Several states enacted parallel measures. ${ }^{128}$ These statutes starkly reveal firm commitment to religious pluralism by subjecting even incidental restrictions on religious groups to strict scrutiny, thereby requiring frequent special accommodations and exceptions for religious groups. ${ }^{129}$

Here too, though, the embrace of accommodation has its limits. Some limits are uncontroversial; for example, organized society cannot accommodate a religious group's obligation to commit ritual murder, no matter how sincerely held the religious belief is. ${ }^{130}$ Thus, RFRA and the other laws modeled on it do not impose a universal requirement that lawmakers accommodate religious practices. ${ }^{131}$ Where a law is the least restrictive means of achieving a compelling interest, the statute satisfies RFRA despite its substantial interference with religious practices. ${ }^{132}$ To be sure, opinions differ as to what constitutes a compelling interest and how to apply the "least restrictive means" test. ${ }^{133}$

126. Religious Freedom Restoration Act of 1993, Pub. L. No. 103-141, 107 Stat. 1488 (codified at 42 U.S.C. $§ \S 2000 b b-2000 b b-4$ (1994)).

127. Religious Land Use and Institutionalized Persons Act, Pub. L. No. 106-274, 114 Stat. 803 (codified at 42 U.S.C. $\$ \$ 2000 c c-2000 c c-5$ (2000)).

128. See generally Christopher C. Lund, Religious Liberty After Gonzales: A Look at State RFRAs, 55 S.D. L. REV. 466 (2010) (discussing state RFRAs). For an updated list of state RFRAs, see State Religious Freedom Restoration Acts, NAT'L CONF. OF State Legislatures (June 5, 2015), http://www.ncsl.org/re search/civil-and-criminal-justice/state-rfra-statutes.aspx (last visited Jan. 19, 2016) (on file with the Washington and Lee Law Review).

129. See Lund, supra note 128, at 5 (providing the operative part of Arizona's RFRA statute establishing a strict scrutiny analysis requirement).

130. As compared to a state law establishing neutral and generally applicable laws that also hinder a group's practice of an essential religious ritual. See Emp't Div. v. Smith, 494 U.S. 872, 890 (1990) (disqualifying certain individuals, who ritually consumed peyote, from unemployment benefits).

131. They do, however, limit governmental interference. See Lund, supra note 128 , at 5 ("Government may substantially burden a person's exercise of religion only if . . ." (emphasis added)).

132. See 42 U.S.C. § 2000bb-1 ("Government may substantially burden a person's exercise of religion only if it demonstrates that application of the burden to the person ... is the least restrictive means of furthering that compelling governmental interest.").

133. Id. 
The large volume of litigation attests to the magnitude of disagreement on the extent of protection offered by RFRA and similar statutes. ${ }^{134}$

Federal antidiscrimination laws further demonstrate the limits of statutory pluralism in the United States. The federal Civil Rights Act, the Fair Housing Act, and so on, include no exceptions for religious groups and individuals, and state laws in these areas have mostly followed suit. ${ }^{135}$ Recent legislative debates concerning extending such laws to protect people on the basis of sexual orientation often revolve around whether, when, and how to accommodate religious objectors, ${ }^{136}$ but most states that have passed such statutes have declined to include religious exceptions (except to religious non-profit institutions). ${ }^{137}$ At times, courts have held that the Constitution protects some groups' rights to discriminate on the grounds of speech interests or religious freedom but in these cases, the legislatures have largely decided that the state's interest-whether economic, philosophical, or dignitary-in prohibiting certain forms of discrimination overrides the general commitment to religious accommodationism. ${ }^{138}$

Finally, lawmakers sometimes reject requested religious accommodations and restrict religious practices for a variety of other reasons: animus, mistrust, indifference, lack of awareness,

134. See generally, e.g., Burwell v. Hobby Lobby Stores, Inc., 134 S. Ct. 2751, 2785 (2014) (finding that the RFRA protected closely-held for-profit corporations from the HHS contraceptives mandate); Gonzales v. O Centro Espirita Beneficente Uniao do Vegetal, 546 U.S. 418 (2006) (interpreting the RFRA to allow an exemption from the Controlled Substances Act for the use of hoasca).

135. Civil Rights Act of 1964, 42 U.S.C. $\$ \S 2000 \mathrm{e}-2000 \mathrm{e}-17$ (2012); Fair Housing Act, 42 U.S.C. §§ 3601-3619 (2012).

136. See, e.g., Nick Smith, Sexual Orientation Discrimination Bill Debated, BISMARCK TRIB. (Mar. 23, 2015), http://bismarcktribune.com/news/local/govtand-politics/sexual-orientation-discrimination-bill-debated/article_12dba165-

95e8-5230-81e9-9eda8b517049.html (last visited Jan. 20, 2016) (discussing the debate about a sexual discrimination bill and its effects on religious freedom) (on file with the Washington and Lee Law Review).

137. See Elane Photography, LLC v. Willock, 309 P.3d 53, 59 (N.M. 2013) (holding that the New Mexico Human Rights Act does not provide an exception for a photographer that refuses to photograph a commitment ceremony between two women).

138. See id. (finding that the New Mexico Human Rights Act does not violate the Free Exercise Clause of the First Amendment because it is a neutral law of general applicability). 
political self-interest, and so forth. ${ }^{139}$ The more countercultural and foreign the religious practice-the more "different" in other words-the more it is at risk. ${ }^{140}$ Lawmakers violate the Constitution when they attempt to impose restrictions on religious practices for some or all of these reasons, ${ }^{141}$ but the existence of such cases reflects the degree to which our dominant accommodationist tendencies are inconsistently embraced in the majoritarian branches.

\section{Understanding Inconsistency: Religious Accommodation and Non-Accommodation in the Political Economy}

As we have seen, the United States is a fairly accommodating nation for religious groups, but those accommodations are inconsistently granted. ${ }^{142}$ We now identify certain troubling aspects of this lack of consistency and consider the political forces that produce it. We conclude this Part by arguing that a greater degree of consistency is necessary for ethical and legal reasons.

139. See Levin, Rethinking Religious Minorities, supra note 1, at 1672 (discussing how the ordinance banning animal sacrifice was a result of mistrust or animus towards adherents of Santería (citing Church of the Lukumi Babalu Aye, Inc. v. City of Hialeah, 508 U.S. 520, 534-39 (1993))).

140. See id. (finding a facially valid law unconstitutional as applied when town officials specifically removed Jewish banners from public street poles while leaving other banners in place (citing Tenafly Eruv Ass'n, Inc. v. Borough of Tenafly, 309 F.3d 144, 178 (3d Cir. 2002))); see also Awad v. Ziriax, 670 F.3d 1111, 1116-18 (stating that Oklahoma passed a constitutional amendment preventing courts from considering Sharia law (Islamic religious law)); Laurie Goodstein, Across Nation, Mosque Projects Meet Opposition, N.Y. TIMES (Aug. 7, 2010), http://www.nytimes.com/2010/08/08/us/08mosque.html?pagewanted=all (last visited Jan. 20, 2016) (discussing the zoning arguments against mosques) (on file with the Washington and Lee Law Review).

141. See Church of the Lukumi Babalu Aye, Inc. v. City of Hialeah, 508 U.S. 520,579 (1993) (holding that a city ordinance prohibiting animal sacrifice was unconstitutional because it was directed at adherents of Santería); see also infra note 269 and accompanying text (noting that Jehovah's Witnesses refuse blood transfusions primarily because of their obedience to God).

142. See supra Part II.C (comparing the differing approaches taken by the judicial and legislative branches with regard to religion and freedom of speech). 
A. Is Inconsistency Troubling? In This Case, Yes.

Differences in the accommodation of claims for different sorts of religious accommodations are not in themselves surprising or necessarily troubling. ${ }^{143}$ There are good arguments for and against such accommodations, ${ }^{144}$ and so we would not expect any liberal democracy to be either absolutely accommodating or absolutely unaccommodating. Thus, it is not difficult to understand why we prohibit religiously motivated murder even while we embrace many other religious accommodations. ${ }^{145}$ There is no contradiction here, for there is broad agreement that in the extreme case of human sacrifice, the liberal values that require society to protect human life and impose an absolute ban on private killings easily supersede the values favoring individual religious freedom. ${ }^{146}$

Thus, some of our laws that decline to accommodate religious objectors can be understood as principled efforts to balance the benefits of religious liberty against its costs. ${ }^{147}$ If all of the laws

143. As seen in Employment Division $v$. Smith, generally applicable laws that are neither intended to limit nor applied to limit, nor only incidentally limit, religious freedom are subject to a weaker scrutiny analysis. See 494 U.S. 872, 878 (1990) ("[I]f prohibiting the exercise of religion (or burdening the activity of printing) is not the object ... but merely the incidental effect of a generally applicable and otherwise valid provision, the First Amendment has not been offended.").

144. See supra Part II.B (discussing the development, and loosening of, strict scrutiny analyses in freedom of religion case law).

145. States have an interest in protecting their residents and, under their police powers, have the power to establish laws governing health, safety, and welfare. See Barnes v. Glen Theatre, 501 U.S. 560, 569 (1991) ("The States' traditional police power is defined as the authority to provide for the public health, safety, and morals, and such a basis for legislation has been upheld.").

146. A similar analogy can be made to abortion cases. For example, the Supreme Court in Planned Parenthood of Southeastern Pennsylvania v. Casey, found that, at the beginning of the third trimester of pregnancy, the state has a compelling interest in protecting the life of the mother and the child, thus permitting a state to illegalize third trimester abortions. 505 U.S. 833, 872 (1992).

147. Hence the focus on a law's intent and the degree to which it impairs the free exercise of religion; if a state passes a general law that happens to incidentally affect the free exercise of religion without intent to do so, the courts interpret this as a legitimate use of state power. See Smith, 494 U.S. at 881 ("The only decisions in which we have held that the First Amendment bars application of a neutral, generally applicable law to religiously motivated action have involved not the Free Exercise Clause alone, but the Free Exercise Clause 
concerning minority religious rights and their limits reflected such a principled approach, then we would be unconcerned with the lack of uniformity. Further, recognizing that different policymakers and communities may balance the interests differently in specific cases, we would even expect and accept for different laws to encode different policymakers' views as to the proper balance. ${ }^{148}$ Indeed, a multi-ethnic, multi-cultural, multi-jurisdictional society such as ours is sure to produce varying policies.

Perhaps the most noncontroversial operative balancing principle is that a religious practice that imposes significant costs or harms on participants in the practice or on third parties should not be tolerated, but that in the absence of such harm, we should be entirely accommodating of religious minorities' deviations from general social and legal expectations. ${ }^{149}$ This essentially encodes a Millian view that one person's rights stop at another's nose. ${ }^{150}$ Under this approach, virtually all would agree that ritual murder imposes a significant harm, and therefore that it cannot be tolerated. ${ }^{151}$ In other cases, however, different groups will have different views as to what constitutes a third-party cost or harm that is significant enough to overcome American baseline accommodationism. ${ }^{152}$

in conjunction with other constitutional protections ....”).

148. A perfect example of biased policymaker views that the court found troubling can be found in United States v. Windsor. See 133 S. Ct. 2675, 2693 (2013) ("The House concluded that DOMA expresses "both moral disapproval of homosexuality, and a moral conviction that heterosexuality better comports with traditional (especially Judeo-Christian) morality." (citing H.R. REP. No. 104-664, at $16(1996))$ ).

149. As seen in Wisconsin v. Yoder, the government had an interest in an educated citizenry, but the additional two years of required attendance did not outweigh the burden placed on Amish people because the additional two years would do little to promote the state interest. 406 U.S. 205, 222 (1972).

150. See Burwell v. Hobby Lobby Stores, Inc., 134 S. Ct. 2751, 2791 (2014) (Ginsburg, J., dissenting) ("In sum, with respect to free exercise claims no less than free speech claims, "[y]our right to swing your arms ends just where the other man's nose begins." (quoting Zechariah Chafee, Jr., Freedom of Speech in War Time, 32 Harv. L. Rev. 932, 957 (1919))); John Stuart Mill, On Liberty 22-23 (1859) (explaining that liberty should be without impediment as long as it does not harm others).

151. See supra note 145 and accompanying text (discussing states' inherent police powers to protect the health and safety of the people within their state).

152. Take, for example, polygamy. While polygamy was a part of the 
The question of what constitutes a harm-or enough of a harm-is not a trivial or easy one. ${ }^{153}$ To take a straightforward example, if we accommodate a Sabbath-observant Jew's religious need to leave her office early enough on a winter Friday to make it home in time for the Sabbath, there may well be a cost imposed on third parties-namely, the coworkers who must fill in during her absence. ${ }^{154}$ Reasonable minds can differ as to whether such costs are significant enough to outweigh the value of religious liberty. It may depend on the type of job and nature of the work. ${ }^{155}$ It may depend on the quality of the relationships between the coworkers. It may depend on the degree to which all coworkers enjoy workplace flexibility to observe their own holidays, take care of loved ones, or pursue interests that are important to them at the expense of work hours. And different people may simply have different levels of tolerance for this kind of cost being imposed on them. Consequently, we would not be surprised if different workplaces adopt different policies or norms on this question or if there are few hard and fast laws that provide certainty for how to resolve individual cases. ${ }^{156}$ Thus,

Mormon religion, states have consistently passed laws prohibiting it that have survived challenges in court, finding the states interest in preserving monogamy compelling. See Potter v. Murray City, 760 F.2d 1065, 1070 (1985) ("Monogamy is inextricably woven into the fabric of this country's society .... In light of these fundamental values, the state is justified, by a compelling interest, in upholding and enforcing its ban on plural marriage to protect the monogamous marriage relationship.”); Barlow v. Blackburn, 798 P.2d 1360, 1365 (Ariz. Ct. App. 1990) ("[W]e find that, assuming that Barlow's practice of polygamy is constitutionally protected, Arizona's compelling state interest, as described below, justifies an infringement upon Barlow's religiously-motivated conduct.").

153. Compare Blackburn, 798 P.2d at 1365 (finding preservation of monogamy a compelling state interest), with Yoder, 406 U.S. at 222 (finding an interest in school attendance insufficiently strong to overcome the burden on religion placed on Amish groups).

154. See Estate of Thornton v. Caldor, Inc., 472 U.S. 703, 710-11 (1985) ("We hold that the Connecticut statute, which provides Sabbath observers with an absolute and unqualified right not to work on their Sabbath, violates the Establishment Clause of the First Amendment."). The statute in Thorton violated the Establishment Clause because it was not secular; the "primary effect" of a law "must not advance or inhibit religion." Id. at 708.

155. See id. at 711-12 (O'Connor, J., concurring) (noting that Establishment Clause protection applies only to government action, not that of private employers).

156. What case law does make clear is that states cannot establish laws mandating private employers to give time off for one particular religious group, 
rules in different places may appear inconsistent with one another on their surface, but they are at least consistent to the extent that they appropriately consider the conflict between the same underlying values.

What is troubling, however, is that many of our laws seem to lack any principled balancing at all. That is, there seem to be no principles at play in the degree to which we permit or limit religious freedom in individual cases. Sometimes we allow religious groups to impose significant costs and harms on third parties; consider, for instance, parents who refuse to vaccinate their children against deadly diseases for reasons of religion, thus putting at grave risk both their own children and other children who cannot be successfully vaccinated. ${ }^{157}$ Or consider parents who are shielded by law from criminal charges when they withhold necessary medical treatment from their children for religious reasons. ${ }^{158}$ Here, we seem to have embraced an extreme

especially when doing so would substantially burden the private employer. See id. at 709-10 ("[T]here is no exception when honoring the dictates of Sabbath observers would cause the employer substantial economic burdens or when the employer's compliance would require the imposition of significant burdens on other employees required to work in place of the Sabbath observers."). However, states may pass laws of general applicability that affect an entire group that may contain members of a particular faith. See Braunfeld v. Brown, 366 U.S. 599, 606-10 (1961) (finding a Pennsylvania law requiring stores to be closed on Sundays valid, even though Orthodox Jews claimed that it imposed an undue burden because the law did not target Jews as a group).

157. See supra notes 117-118 and accompanying text (discussing statutes mandating vaccination before entry into public schools); see also Michaeleen Doucleff, How Vaccine Fears Fueled the Resurgence of Preventable Diseases, NPR (Jan. 25, 2014), http://www.npr.org/blogs/health/2014/01/25/265750719/ how-vaccine-fears-fueled-the-resurgence-of-preventable-diseases (last visited Jan. 21, 2016) (listing the rise of several preventable diseases such as measles, whooping cough, and rubella, to name a few) (on file with the Washington and Lee Law Review); Alexandra Sifferlin, 4 Diseases Making a Comeback Thanks to Anti-Vaxxers, Time (Mar. 17, 2014), http://time.com/27308/4-diseases-making-acomeback-thanks-to-anti-vaxxers/ (last visited Jan. 21, 2016) (noting the rise of preventable diseases, including measles, in New York City) (on file with the Washington and Lee Law Review).

158. See Levin, Rethinking Religious Minorities, supra note 1, at 1654-55 (arguing that, if posed the question of the constitutionality of universal vaccination laws, the Court would find that religious individuals would not be exempt on religious grounds). But see, e.g., State v. Neumann, 832 N.W.2d 560, 591 (Wis. 2013) (ruling that prosecuting parents for reckless homicide because they did not seek medical treatment for their child did not violate the parents' free exercise rights). 
degree of religious liberty that ignores severe harms to children and third parties. ${ }^{159}$

On the other hand, sometimes statutes or regulations prohibit the exercise of religious freedom even where there is little or no harm to anyone. Consider, for example, the plaintiff in Smith, who wished to use controlled substances as part of his religious worship ceremonies but was denied even though the Government could articulate no third party harms, or even harms to the people who used the drugs in their rituals. ${ }^{160}$ Also consider the plaintiff in Holt $v$. Hobbs, ${ }^{161}$ a prisoner who wished to grow a beard of one half inch in length to comply with his religious beliefs but was denied for reasons so transparently baseless that Supreme Court Justices laughed at them. ${ }^{162}$ In these cases and others, ${ }^{163}$ there is apparently no regard for the value of religious liberty despite the absence of documented harm to any individual.

In short, the puzzle is not that individual laws appear to reflect different assessments of how to balance the underlying principles, but rather that there appear to be no consistent principles in play. Why?

159. See Janna C. Merrick, Spiritual Healing, Sick Kids and the Law: Inequities in the American Healthcare System, 29 AM. J.L. \& MED. 269, 297 (2003) (arguing that members of a pluralistic society should value the rights of children and their health over the rights of parents who constitute a religious minority).

160. See Emp't Div. v. Smith, 494 U.S. 872, 890 (1990) (denying unemployment benefits to individuals who took peyote for religious purposes).

161. 135 S. Ct. 853 (2015).

162. See id. at 859 (finding that a jail's no-beard policy was not the least restrictive means of furthering its compelling interest in preventing the trafficking of contraband).

163. See Levin, Rethinking Religious Minorities, supra note 1, at 1675 (discussing how there was clear animosity directed towards particular religious groups in Tenafly and Lukumi); see also Church of Lukumi Bablu Aye v. City of Hialeah, 508 U.S. 520, 540 (1993) (invalidating state laws that suppressed animal sacrifice); Awad v. Ziriax, 670 F.3d 1116, 1132-33 (10th Cir. 2012) (invalidating a state anti-Sharia law statute); Tenafly Eruv Ass'n, Inc. v. Borough of Tenafly, 309 F.3d 144, 168 (3d Cir. 2002) (holding that the borough violated the Free Exercise Clause by enforcing an ordinance selectively against Orthodox Jewish conduct); Danika Fears, Developer Ditches Plan for 'Ground Zero Mosque,' N.Y. Post (Apr. 30, 2014), http://nypost.com/2014/04/30/developerditches-ground-zero-mosque-to-create-museum-for-islam/ (last visited Jan. 22, 2016) (explaining that a mosque was allowed to be built at Ground Zero following expressed outrage) (on file with the Washington and Lee Law Review). 


\section{B. Explaining Inconsistency: Religious Groups in the Political Economy}

The apparent absence of consistency in our provision of religious accommodations can best be explained by basic insights of a school of political science known as public choice theory. ${ }^{164}$ Public choice theory seeks to understand political decisions and behavior by considering the incentives and self-interest of stakeholders ${ }^{165}$ and policymakers. Public choice theory is concerned with how even small interest groups are able to influence and capture the political process. ${ }^{166}$

In applying this approach to the question of religious accommodation, it is useful to think of religious groups as functioning like any other special interest group in society, although few religious groups, politicians, or voters choose to express it this way. ${ }^{167}$ Once we orient ourselves in this manner, we can quite readily understand why the decision to grant or refuse religious accommodations is often unmoored from consideration of underlying values and, consequently, yields inconsistent and incoherent results. ${ }^{168} \mathrm{We}$ also can model the circumstances in which the political branches will under-protect and overprotect religious liberty.

To be clear at the outset, we define "religious interest groups" broadly, to include everything from those groups that operate through sophisticated and official lobbying arms, ${ }^{169}$ to those that

164. See Jonathan R. Macey, Public Choice: The Theory of the Firm and the Theory of Market Exchange, 74 CORNELL L. REV. 43, 43 (1988) (considering the social and economic impacts on legislation).

165. See id. at 50 (discussing how powerful interest groups and lobbyists negatively affect, for example, environmental legislation and lead to ineffective laws that greatly benefit certain interest groups at the expense of others).

166. See id. at 48 (noting that some of the most politically powerful interest groups are small in size).

167. See Levin, Rethinking Religious Minorities, supra note 1, at 1663 (recognizing that the Religious Freedom Restoration Act was heavily lobbied for by small religious groups).

168. See supra Part II.C (discussing the inconsistency of freedom of religion case law).

169. See, e.g., Lauren Markoe, Liberal Jewish Group Launches Political Lobbying Arm, WASH. Post (July 26, 2012), http://www.washingtonpost.com/ national/on-faith/liberal-jewish-group-launches-political-lobbying-arm/2012/07/25/ gJQAsC8Z9W_story.html (last visited Jan. 21, 2016) (describing how a liberal 
operate-particularly at the local level of governance-on an ad hoc basis by offering to politicians and lawmakers a coherent and cohesive audience and, potentially, a reliably supportive voting bloc. ${ }^{170}$ An example of the former is Moral Majority, associated with the Christian right; 171 a hypothetical example of the latter is a priest who calls a local politician to explain his church's need for a no parking zone nearby. ${ }^{172}$

The similarities between how religious groups and other interest groups operate in the policymaking arena are striking and make the case for why we should analyze the behavior of religious groups in this manner. Like other interest groups, religious groups aim to maximize their political influence to shape public policy in a manner that represents the groups' interests on issues they care about. ${ }^{173}$ A religious interest group may focus on a single issue, may represent its own interests broadly, or may participate in a coalition of religious and perhaps other groups. ${ }^{174}$ As with other interest groups, some religious groups are more organized, powerful, and successful than

Jewish group, Bend the Arc, has initiated lobbying activities) (on file with the Washington and Lee Law Review); About JFNA, JEwISH FED'Ns of N. AM., http://jewishfederations.org/about-jfna (last visited June 21, 2015) (stating that the group lobbies in Washington, D.C. to get $\$ 10$ billion in public funds for Jewish communities) (on file with the Washington and Lee Law Review).

170. See Levin, Rethinking Religious Minorities, supra note 1, at 1663 (explaining that elected officials have an incentive to work with religious groups that may provide them with support and votes).

171. See Robert C. Liebman \& Robert Vuthnow, The New Christian Right: Mobilization AND Legitimation 54-55 (1983) (describing the Moral Majority as a lobbying arm to influence legislation that "became the byword for the entire New Christian Right").

172. For an in-depth discussion of this sort of ad hoc accommodationism in action, see Levin, Rethinking Religious Minorities, supra note 1 at 1635-42 (discussing the experience of a religious community in Memphis, Tennessee that received favorable treatment from local officials).

173. See Zoë Robinson, Rationalizing Religious Exemptions: A Legislative Process Theory of Statutory Exemptions in Religion, 20 WM. \& MARY BILL RTS. J. 133, 135 (2011) [hereinafter Robinson, Rationalizing Religious Exemptions] (explaining the premise that political actors act in a way to maximize the value of political outcomes for themselves).

174. See Zoë Robinson, Lobbying in the Shadows: Religious Interest Groups in the Legislative Process, 64 EMORY L.J. 1041, 1045 (2015) [hereinafter Robinson, Lobbying in the Shadows] (discussing the range of religious groups from well-known church lobbies to lesser-known coalitions and single-issue groups). 
others. ${ }^{175}$ And, like other interest groups, they sometimes have interests that overlap with those of other interest groups and lead them to work together in pursuit of common goals. ${ }^{176}$

The interests that religious groups pursue may include the reification into law of religiously motivated stances on broad public policy issues like abortion, ${ }^{177}$ education, ${ }^{178}$ same-sex marriage, ${ }^{179}$ drug policy, ${ }^{180}$ immigration, ${ }^{181}$ criminal law, ${ }^{182}$ and more; and they can also include practical issues of concern primarily to the religious group itself, such as securing permits to build a house of worship or obtaining religious exemptions from laws that may impede specific religious practices. ${ }^{183}$

If religious interventions in the political sphere are so conceptualized, it becomes possible to apply public choice theory to understand why religious groups sometimes win and sometimes lose without any apparent principles explaining when

175. See Levin, Rethinking Religious Minorities, supra note 1, at 1682 (describing how the nature of interest group politics results in stronger religious groups winning battles against less-organized and less-powerful minority groups).

176. See id. at 1662 ("[Religious groups] therefore tend to work together to lobby for religious accommodations, both in the legislature and in the courts.").

177. See Robinson, Lobbying in the Shadows, supra note 174, at 1080 ("Religious interest groups including Priests for Life, Texas Right to Life, Concerned Women of America for Texas, and Texas Alliance for Life actively pursue the restriction of the availability of abortions in America.").

178. See id. at 1065 (discussing the educational goals of the Association of Jesuit Colleges and Universities).

179. See id. ("The interests of the USCCB advocated for by the OGR include prohibition of same-sex marriage ....").

180. See Levin, Rethinking Religious Minorities, supra note 1, at 1648 (stating that federal legislative exceptions, exemptions, and accommodations granted to religious institutions include regulation of drug laws).

181. See id. (stating that federal legislative exceptions, exemptions, and accommodations granted to religious institutions include regulation of immigration).

182. See, e.g., Ryan, supra note 113, at 1446 (discussing the exemption from gambling laws given to religious groups).

183. See, e.g., Charlie Frago, Clearwater Issues Conditions Scientology Must Meet to Hold its Events, TAMPA BAY TIMES (Nov. 8, 2012), http://www. tampabay.com/news/scientology/clearwater-issues-conditions-scientology-must-meetto-hold-its-events/2151572 (last visited Jan. 21, 2016) (stating that the Church of Scientology had to obtain permits for tents and fences) (on file with the Washington and Lee Law Review). 
or why. ${ }^{184}$ Interest groups compete in the political marketplace alongside, and sometimes against, other interest groups. ${ }^{185}$ In the modern American political marketplace, good policy and coherent principles are not the primary determinants of the laws that are enacted. ${ }^{186}$ Rather, like all other rational actors, politicians and other policymakers respond to incentives. ${ }^{187}$ To the extent that laws enacted represent good policy and coherent principles, they generally do so because the lawmakers' incentives are aligned with those values. ${ }^{188}$

At the same time, laws are not decided on the basis of pure majority preferences. ${ }^{189}$ This is because the incentives for policymakers do not revolve around what the majority prefers, but rather around the complicated interaction between voter preferences, the magnitude of those preferences, and the levels of support-voting, financial, or other-that competing blocs of voters can deliver. ${ }^{190}$ Thus, a small but organized and focused interest group will often achieve its policymaking goals even when it externalizes heavy costs on society at large, if the forces that might object to the policy are disorganized, dispersed throughout society, and of relatively low priority to potential

184. See Robinson, Rationalizing Religious Exemptions, supra note 173, at 135 ("The public choice model supposes that any exemptions and accommodations for religion enacted by the legislature are the product of the conflation of religious lobbying efforts and the individual self-interest of legislators.").

185. See id. at 145 (explaining that religious firms compete for policy outcomes).

186. See id. at 148-49 (stating that legislators will enact legislation primarily for reelection).

187. See id. at 143-44 (discussing that one aspect of the public choice is the positive theory, which assumes that politicians will act rationally to maximize their interest).

188. See Robinson, Lobbying in the Shadows, supra note 174, at 1100-01 (explaining how legislators are "benefit maximizers" and act based on incentives).

189. See Levin, Rethinking Religious Minorities, supra note 1, at 1663 ("Even in the absence of coordinated lobbying by diverse religious groups, elected officials may still have political incentives to work with small religious groups.").

190. See Robinson, Lobbying in the Shadows, supra note 174, at 1076 (describing how politicians respond to religious interest groups that represent large voting blocs and will help the groups that attract the most votes). 
opponents. ${ }^{191}$ In short, a focused minority group often will defeat a numerically overwhelming but disorganized majority, or a majority for whom the issue is not a priority. ${ }^{192}$ This is because the focused minority group can reliably deliver votes and other means of support to a politician or other policymaker, who therefore responds to the group's policy preferences; whereas the amorphous "larger public good" can deliver no support at all. ${ }^{193}$

These dynamics amply explain why religious groups have been so successful in the legislative, executive, and administrative arenas in obtaining religious accommodations even when these were not constitutionally required according to the Supreme Court's jurisprudence. ${ }^{194}$ Indeed, thousands of statutes and regulations include religious accommodations in areas ranging from tax law to employment law, criminal law to regulations governing food preparation, and healthcare law to zoning ordinances, most of which are not required by the Constitution. ${ }^{195}$ For instance, after the Supreme Court upheld a military regulation prohibiting service members from wearing religious garb, Congress voted to generally permit it. ${ }^{196}$ Likewise, when the Court held that the Constitution did not require an accommodation that would allow Native American Peyotists to ingest peyote, Congress passed a law permitting it. ${ }^{197}$ And, of

191. See Levin, Rethinking Religious Minorities, supra note 1, at 1664 (explaining that "a concentrated and focused interest group" is often successful over a "diffuse opposition that ranks the issue low among their priorities").

192. See id. at 1667 (stating that the political realities, not just a group's headcount, must be considered when assessing a group's political power).

193. See id. at 1663 (explaining that politicians will be willing to help out religious minorities who otherwise would not have a voice because the politicians recognize that certain groups that are minorities are more likely to be politically active than other groups).

194. See Ryan, supra note 113, at 1445-46 (discussing various areas where the legislature has carved out religious exceptions, including inspection and tax law).

195. See id. ("Religious exemptions, in turn, exist in over 2,000 statutes.").

196. Compare Goldman v. Weinberger, 475 U.S. 503, 510 (1986) (stating that the Air Force's dress code policy is related to the military's interest in having a uniform dress code, and therefore, the Air Force has not violated the petitioner's First Amendment right), with 10 U.S.C. $\$ 774$ (2012) (explaining that "a member of the armed forces may wear an item of religious apparel while wearing the uniform of the member's armed force" except when the apparel would interfere with the member's ability to perform his duties).

197. Compare Emp’t Div. v. Smith, 494 U.S. 872, 890 (1990) ("But to say 
course, after the Supreme Court ruled in Smith that neutral, generally applicable laws need not include exceptions and accommodations for religious minority groups, Congress and several state legislatures responded by enacting laws like RFRA and the Religious Land Use and Institutionalize Persons Act (RLUIPA) to establish minority religious rights that would be free from legislative and administrative incursions that might be supported by the majority. ${ }^{198}$ In each of these cases, religious interest groups organized focused campaigns to achieve their goals and faced little opposition, either because other interest groups actively supported the accommodation or simply had no organizing interest in fighting it. ${ }^{199}$

These same dynamics also explain why even small minority religious groups are sometimes able to obtain benefits that inflict harm on third parties. ${ }^{200}$ Only a small minority of the population supports immunization exemptions on the basis of religion or conscience, ${ }^{201}$ but this minority is quite focused and motivated. ${ }^{202}$ On the other hand, the lobbies supporting compulsory immunization, consisting principally of various medical organizations, are concerned with multiple issues and are not as

that a nondiscriminatory religious-practice exemption is permitted, or even that it is desirable, is not to say that it is constitutionally required, and that the appropriate occasions for its creation can be discerned by the courts."), with 42 U.S.C. $\$ 1996$ a (2012) (overruling the decision in Smith and making it illegal to prohibit the use of peyote for religious purposes).

198. Religious Freedom Restoration Act of 1993, Pub. L. No. 103-141, 107 Stat. 1488 (codified at 42 U.S.C. $\$ \S 2000 b b-2000 b b-4$ (1994)), invalidated by City of Boerne v. Flores, 521 U.S. 507 (1997); Religious Land Use and Institutionalized Persons Act, Pub. L. No. 106-274, 114 Stat. 803 (2000) (codified at 42 U.S.C. $\S \S 2000 c c$ to $2000 c c-5$ (2012)).

199. See Levin, Rethinking Religious Minorities, supra note 1, at 1645 (explaining that the majority effectively agreed to give the minority special rights when the RFRA was passed).

200. See James G. Hodge, Jr. \& Lawrence O. Gostin, School Vaccination Requirements: Historical, Social, and Legal Perspectives, 90 KY. L.J. 831, 848 (2001-2002) (discussing how the minority view has been effective in protesting mandatory vaccinations, despite the harm that can be caused by allowing some people to avoid being vaccinated).

201. See id. (describing the minority anti-vaccinationist sentiment).

202. See id. ("Antivaccinationist sentiment largely remained the view of a vocal minority, although the fervor with which it was expressed remained influential.”). 
focused. 203 While vaccination exemptions expose everyone in society to increased risks, most people are not motivated enough, except, perhaps, in the wake of a well-publicized medical crisis, to organize in opposition. ${ }^{204}$ The same is true for laws that provide religious exceptions to medical neglect laws; such laws may be bad for children and society at large, but there are few votes to be won by politicians for fighting them. ${ }^{205}$

On the other hand, religious interest groups can lose in the political marketplace as well, and the basic dynamics we have described operate here as well. ${ }^{206}$ A religious interest group will fail to achieve its goals in the political arena where (1) a broad majority becomes focused on defeating it; 207 or (2) the issue puts the religious interest group in competition with another, more powerful interest group. ${ }^{208}$ In addition, the religious interest group may also lose to an evenly matched or smaller competing interest group that is able to exert more influence over policymakers then in power. ${ }^{209}$

203. See Levin, Rethinking Religious Minorities, supra note 1, at 1682 (explaining that groups that are more organized are more likely to be successful in achieving their goals, even if they are advocating the minority view).

204. See Hodge \& Gostin, supra note 200, at 874 ("Virtually all states also grant religious exemptions for persons who have sincere religious beliefs in opposition to immunization.”).

205. See Levin, Rethinking Religious Minorities, supra note 1, at 1654-55 (discussing medical neglect laws and that "there has been too much majoritarianism favoring religious liberty claims").

206. See id. at 1655-56 ("[E]ven when the courts have held back in these areas, rightly recognizing the competing nature of some public interests that might trump free exercise concerns, political decisionmakers have pushed forward nonetheless-effectively protecting religious autonomy even at the expense of countervailing public health and safety interests.").

207. See id. at 1664-65 (offering examples of majority groups focusing on preventing religious accommodation).

208. See id. at 1667 (discussing Burwell v. Hobby Lobby Stores, Inc. and how, "in the political debates that produced the laws in question, the lobbying power of religious liberty groups was diminished, and the lobbying power that remained was met and exceeded by the lobbying power of the opposing side").

209. See, e.g., Peter Baker, President Calls for a Ban on Job Bias Against Gays, N.Y. TIMES (July 21, 2014), http://www.nytimes.com/2014/07/22/us/ politics/obama-job-discrimination-gays-executive-order.html (last visited Dec. 20, 2015) (stating that President Obama faced heavy pressure from organizations representing gays-a Democratic core constituency-before rejecting requests by religious groups to exempt them from the executive order prohibiting discrimination against gays) (on file with the Washington and Lee 
At times, the majority may not tolerate a religious group's preferences because the cost on involved individuals or on third parties is too great, and the religious principles involved seem too outrageous to those outside the religion. ${ }^{210}$ Presumably, this is why, no matter how focused and organized a religious interest group is, society will never tolerate sumptuary laws or laws that permit ritual murder. ${ }^{211}$ Often, though, there are simply basic disagreements between the various groups as to the relative values underlying the policy being debated. ${ }^{212} \mathrm{~A}$ religious interest group may wish to limit women's ability to obtain abortions, whereas a competing women's rights interest group may oppose such limitations. ${ }^{213}$ Or a religious interest group may favor more liberal immigration laws, ${ }^{214}$ whereas a competing labor union may favor more restrictive immigration laws. ${ }^{215}$ However strong the disagreement in these examples, each side is comprehensible to the other, in contrast to the case with permitting ritual murder. ${ }^{216}$ In such cases the relative size and power of the

Law Review).

210. See Levin, Rethinking Religious Minorities, supra note 1, at 1674 ("Laws that prohibit murder are not driven by a desire to harm religious groups that wish to practice human sacrifice but by a widely shared communal belief that the taking of a human life (absent special circumstances) is a moral and ethical evil and harms the interests of society.").

211. See id. (discussing the limits that are placed on religious exemptions for minority groups).

212. See id. at 1666 ("Rather, there are simply issues on which different groups hold opposing views very strongly. Such conflicts may present a zero-sum equation in which either the religious liberty interest or the opposing equality interest can prevail, but not both.").

213. See id. at 1666-68 (discussing interest group lobbying in the Hobby Lobby case).

214. See Michael Lipka, Catholics, Other Christians Support Immigration Reform, But Say Faith Plays Small Role, Pew Research CTR. (Apr. 1, 2014), http://www.pewresearch.org/fact-tank/2014/04/01/catholics-other-christianssupport-immigration-reform-but-say-faith-plays-small-role/ (last visited Dec. 20, 2015) (describing religious groups of a number of different faiths that are supporting immigration reform and many are asking President Obama to use his power as President to limit deportation of immigrants who are already in the United States) (on file with Washington and Lee Law Review).

215. See Developments in the Law Immigration: Policy and the Rights of Aliens, 96 HARV. L. REV. 1286, 1440 (1983) ("Labor unions, fearing that undocumented aliens displace United States workers, have pressed for greater restrictions ....").

216. See Levin, Rethinking Religious Minorities, supra note 1, at 1680-81 
interest groups, their influence over the policymakers then in power, and the policymakers' own personal beliefs, commitments, and assessment of the political risks will determine which side wins. $^{217}$

Sometimes a religious group will lose to the majority in the political sphere because of the majority's base animus toward that group, even where the religious group's practices impose no clear harm on the broader society. ${ }^{218}$ The Lukumi case is such an example. ${ }^{219}$ There, the majority of the citizens in the City of Hialeah were so disgusted by the Santería practice of animal sacrifice - and perhaps by Santería in general-that they passed a law prohibiting animal sacrifice but permitting all manner of animal killing that those outside Santería might choose to engage in. ${ }^{220}$ Likewise, in Tenafly Eruv Ass'n, ${ }^{221}$ the majority of the citizens were so opposed to the establishment of a vibrant Orthodox Jewish community in their town that they enforced a neutral law in a blatantly discriminatory manner to prevent it. ${ }^{222}$ Other cases based in animus may include broad efforts to prohibit Muslims from building houses of worship and attempts to pass

(explaining that often groups on both sides of an issue are sophisticated parties who are able to negotiate with one another).

217. See Robinson, Lobbying in the Shadows, supra note 174, at 1100-01 (explaining how groups that represent the minority opinion are able to enact changes by using the political process to their advantage).

218. See Levin, Rethinking Religious Minorities, supra note 1, at 1664 ("First, when a religious practice or group is perceived to challenge or threaten the majority's cultural norms, all bets are off. In these conditions, the opposition becomes focused and coordinated enough to defeat the religious interest promoted by the minority.").

219. See Church of Lukumi Babalu Aye, Inc. v. City of Hialeah, 508 U.S. 520 , 526-30 (1993) (explaining how in response to the establishment of a Santeria church, the city council passed a law prohibiting the unlawful killing of animals and making it illegal for the church to carry out part of their religious practices of sacrificing animals).

220. See id. at 526-28 ("The prospect of a Santería church in their midst was distressing to many members of the Hialeah community, and the announcement of the plans to open a Santeria church in Hialeah prompted the city council to hold an emergency public session on June 9, 1987.").

221. 309 F.3d 144 (3d. Cir. 2002).

222. See id. at 151-52 (explaining that, although the city ordinance preventing citizens from advertising or placing signs on utility poles or trees in the city applied to all citizens equally, in practice this ordinance was not applied to all people equally). 
laws that ban Sharia law, even to arbitrate private agreements. ${ }^{223}$ Ultimately, the courts may strike down such discriminatory laws as unconstitutional, ${ }^{224}$ but the point is that group animus can sometimes be sufficient to mobilize and focus opponents and defeat a religious interest group through the elected branches even where the principle of pluralism ought to be sustained. ${ }^{225}$

In short, religious groups operate in the political marketplace like other interest groups. ${ }^{226}$ As such, whether they win or lose on a particular political issue is related less to a principled balancing of the competing underlying values than it is to the political dynamics in play. ${ }^{227}$

\section{The Problems with Leaving Accommodations to Politics}

The absence of a principled approach to these issues is deeply troubling. ${ }^{228}$ It is a basic principle of ethics as well as law that like things should be treated alike, ${ }^{229}$ and so we should always be

223. See Fears, supra note 163 (explaining that a mosque was allowed to be built at Ground Zero following expressed outrage); Awad v. Ziriax, 670 F.3d 1111, 1132 (10th Cir. 2012) (invalidating a state anti-Sharia law).

224. See Lukumi, 508 U.S. at 524 ("The challenged laws had an impermissible object; and in all events the principle of general applicability was violated because the secular ends asserted in defense of the laws were pursued only with respect to conduct motivated by religious beliefs."); Tenafly, 309 F.3d at 151 (upholding the injunction that the lower court ordered because the law was facially neutral); Awad, 670 F.3d at 1132 (applying a heightened level of review to uphold the lowers court injunction).

225. See Levin, Rethinking Religious Minorities, supra note 1, at 1664 (discussing how if the minority opinion conflicts with the majorities view point, the majority will use its power to ensure the minority does not prevail).

226. See id. (discussing how the political process plays a vital role in determining which interest group is able to have its voice heard).

227. See id. at 1667 ("[C]areful attention to the political realities in which public officials and religious groups operate illuminates why political majorities so often accommodate religious beliefs and practices, even where the courts do not require them to.").

228. See Hillel Y. Levin, A Reliance Approach to Precedent, 47 GA. L. REV. 1035, 1039 (2013) [hereinafter Levin, Reliance Approach] (explaining why reliance on precedent is concerning and is being used too often).

229. Aristotle, Nicomachean Ethics, Book V 71 (W. D. Ross trans., 1999); see H. L. A. Hart, Positivism and the Separation of Law and Morals, 71 HARV. L. REV. 593, 622-24 (1958) ("The connection between law and moral standards and 
bothered by gross inconsistencies in the law. We can ask why, given that the vast majority of our laws are produced through the very same political dynamic as we have identified in this context, and therefore display similar inconsistencies and pathologies throughout the law, we should be especially wary of this dynamic in the context of religious accommodationism. ${ }^{230}$ Indeed, this formal equality principle is hardly a feature of our system, for the law does, indeed must, tolerate all kinds of inconsistencies. ${ }^{231}$

There are perhaps four possible answers to this question, only one of which we find persuasive. ${ }^{232}$ First, these political dynamics might be so corrosive and pathological that the lawmaking process as a whole should be reordered in a way to reflect greater consistency and principle in the law. ${ }^{233}$ In other words, gross inconsistency is not only, or even especially, a problem in the context of religious accommodation; this is simply the context in which we happen to be writing. ${ }^{234}$ We need not take sides on this position because it is outside the scope of our project.

Second, the context of religious accommodation might warrant special scrutiny because the concerns we have identified take on special force where the rights or interests of small and

principles of justice is therefore as little arbitrary and as 'necessary' as the connection between law and sanctions ....").

230. See Levin, Rethinking Religious Minorities, supra note 1, at 1655 (explaining how the courts have not "adequately delineated the boundary between permissible religious accommodations and impermissible ones").

231. See Levin, Reliance Approach, supra note 228, at 1039 (discussing the way that the courts apply precedent often results in inconsistent outcomes and the way that precedent is applied should be reevaluated).

232. See id. at 1044 (explaining that the debate about precedent is not a new debate and that there have been several theories on the issue); David L. Shapiro, The Role of Precedent in Constitutional Adjudication: An Introspection, 86 TEx. L. REv. 929, 929 (2008) ("In recent years, there has been a surprising outpouring of academic literature on the proper role of precedent in constitutional cases.").

233. See Shapiro, supra note 232, at 935 (explaining that some scholars believe that the law should be applied strictly adhering to the constitution and precedent).

234. See Drew C. Ensign, Note, The Impact of Liberty on Stare Decisis: The Rehnquist Court from Casey to Lawrence, 81 N.Y.U. L. REV. 1137, 1141 (2006) ("At the Supreme Court level, it generally requires that the Court adhere to its prior resolution of a particular issue, even if a majority of the Court believes that the prior decision is flawed."). 
marginalized religious minority groups, children, and unaware third parties are at stake and are at the mercy of the whims and power dynamics of the political marketplace. ${ }^{235}$ The competing rights and interests of both sides in these cases-disfavored religious minority groups on the one hand and children and the silent public on the other-are already underrepresented and under-protected in the political arena, ${ }^{236}$ and we should aim to do better than merely accept that the political marketplace will decide the fate of such groups according to its internal political dynamics rather than by reference to underlying values. This views the problems with our political system through an Ely-esque lens ${ }^{237}$ and suggests that there are certain contexts in which the political system alone, given its pathologies, cannot be left to operate as it normally does. To be clear, this merely narrows the universe of cases in which we should reject "politics as usual"-it does not limit these cases to the religious context because there are many other underrepresented groups who cannot get a fair shake in the political system. ${ }^{238}$ For our part, we agree with this critique as an ethical matter-legislators should do better by bringing a principled approach to these questionsbut we cannot say that the Constitution demands this approach.

A third possible response is that religion is indeed special and deserving of special protection under the Constitution. ${ }^{239}$ Proponents of this approach are those who believe the Supreme

235. See Levin, Rethinking Religious Minorities, supra note 1, at 1655-56 (explaining how precedent differs when religion is at issue because of the various issues that are presented with religion issues before the courts).

236. See id. ("[R]ecognizing the competing nature of some public interests that might trump free exercise concerns, political decision makers have pushed forward nonetheless-effectively protecting religious autonomy even at the expense of countervailing public health and safety interest.").

237. See generally John Hart Ely, Democracy AND Distrust: A Theory of JUDICIAL REVIEW (1980) (explaining John Ely's view that the courts should strive to protect both the majority position while also guarding the minorities' rights).

238. See Levin, Rethinking Religious Minorities, supra note 1, at 1623-24 (noting that the minority position is not always protected by the political process).

239. See McConnell, Accommodation of Religion, supra note 20, at 688-89 ("Accommodations of religion are government policies that take religion specifically into account not for the purpose of promoting the government's own favored form of religion, but of allowing individuals and groups to exercise their religion-whatever it may be-without hindrance."). 
Court got Smith wrong. ${ }^{240}$ They would maintain that the unpredictable and unprincipled political process that sometimes produces too little accommodation cannot be trusted to adequately protect the constitutional value of religious free exercise. ${ }^{241}$ But our project is not to re-litigate the merits of Smith, and so we do not rest on this justification either. Also, it is critical to note that this approach would only touch one side of the equation: under-accommodation of religious practices would be of constitutional concern, but over-accommodation as a result of the political economy dynamic we have identified would be acceptable. ${ }^{242} \mathrm{We}$, in contrast, are bothered by both. Furthermore, Smith is unlikely to be reversed in the near to intermediate term, and a serious discussion of religious accommodations must accept a legal regime in which Smith is good law. ${ }^{243}$

Instead, we offer a fourth reason that we should demand more than "politics as usual" in the context of religious accommodations that potentially harm children or third parties: both sides of the equation implicate constitutional values. On the one hand, the Free Exercise Clause embodies a respect for religious liberty and, at the very least, demands that individuals and groups not be prevented from practicing their religious obligations as a result of bias, animus, or stereotyping on the part of lawmakers and officials. ${ }^{24}$ Further, to the degree that different

240. See Marc O. DeGirolami, Predictably Unpredictable: Thoughts on the Free Exercise Clause, CTR FOR L. \& RELIGION For. (Mar. 8, 2013), http://clrforum.org/2013/03/08/predictably-unpredictable-thoughts-on-the-freeexercise-clause/ (last visited on Dec. 23, 2015) (explaining how Smith has produced an unpredictable outcome that the opinion aimed to eliminate) (on file with Washington and Lee Law Review).

241. See Levin, Rethinking Religious Minorities, supra note 1, at 1621-22 (noting that Douglas Laycock, a well-known scholar and advocate of religious freedom, has warned that Smith will produce an outcome that will lead the minority religious groups not being properly represented).

242. See id. at 1652-56 (describing how majoritarian institutions have sometimes been more likely to over-accommodate minority religious groups, more than is required by the courts and the Constitution).

243. See DeGirolami, supra note 240 (noting that the Smith decision has been followed).

244. See U.S. ConsT. amend. I ("Congress shall make no law respecting an establishment of religion . . . ."); Church of Lukumi Bablu Aye v. City of Hialeah, 508 U.S. 520, 538 (1993) ("We also find significant evidence of the ordinances' improper targeting of Santeria sacrifice in the fact that they proscribe more religious conduct than is necessary to achieve their stated ends."); Tenafly Eruv 
religious groups may receive different treatment from legislatures as a result of the political power of the groups, constitutional questions also arise. ${ }^{245}$

On the other hand, religious accommodations that impose harms to children and third parties raise substantial questions under the Establishment Clause. ${ }^{246}$ After all, in permitting a religious practice that harms others who do not choose to subject themselves to the same religious strictures, the state is in effect subjecting some of its citizens to the rule of those favored religions to which those citizens belong. ${ }^{247}$ These competing constitutional values demand careful and principled balancing and consistent resolution on the part of policymakers and judges confronting these cases. ${ }^{248}$ It is not enough to say, "leave it to politics as usual." 249

Ass'n v. Borough of Tenafly, 309 F.3d 144, 168 (3d Cir. 2002) (“[T]he Borough's selective, discretionary application of Ordinance 691 against the lechis violates the neutrality principle of Lukumi and Fraternal Order of Police .....); Levin, Rethinking Religious Minorities, supra note 1, at 1665 ("[T] enacted a facially neutral ordinance against animal sacrifice that was nevertheless clearly directed at . . adherents of Santeria. Citizens were free to kill animals for reasons other than ceremonial sacrifice, and the record was rife with evidence of animus towards practitioners of Santeria.").

245. See Gonzales v. O Centro Espirita Beneficente Uniao do Vegetal, 546 U.S. 418, 432-34 (2006) (discussing the RFRA's exception for peyote and comparing it to hoasca).

246. See Levin, Rethinking Religious Minorities, supra note 1, at 1655 (discussing the line of cases interpreting the Establishment Clause to limit the accommodation of religious practices that harm third parties).

247. See Cutter v. Wilkinson, 544 U.S. 709, 713 (2005) ("This Court has long recognized that the government may...accommodate religious practices... without violating the Establishment Clause." (quoting Hobbie v. Unemployment Appeals Comm'n of Fla., 480 U.S. 136, 144-45 (1987))). See generally Frederick Mark Gedicks \& Rebecca G. Van Tassell, RFRA Exemptions from the Contraception Mandate: An Unconstitutional Accommodation of Religion, 49 HARV. C.R.-C.L. L. REV. 343, 344-49 (2014) (discussing religious exemptions and their effects on third parties).

248. See Levin, Rethinking Religious Minorities, supra note 1, at 1682 (explaining that there are times when the court is unable to properly balance the competing interests at issue).

249. See id. at 1683 ("Thus, although the majoritarian branches and courts may both make poor decisions on such questions, the majoritarian branches enjoy two critical advantages over courts: (a) they can revisit policy choices at will; and (b) they have some majoritarian legitimacy.”). 


\section{Balancing Religious Liberty Against Protection of Children and Third Parties: A Proposed Test}

This Part offers and describes a principled test that balances the competing interests in these cases according to the yin and yang of the First Amendment Free Exercise and Establishment Clauses. ${ }^{250}$ It first lays out the test, then explains it and unpacks its individual provisions, and finally demonstrates how the test would apply in a variety of cases, in some cases tracking current laws and in others requiring different results. ${ }^{251}$

\section{A. The Test ${ }^{252}$}

1. BASES FOR POSSIBLE RESTRICTION: A religious practice related to the needs of its members with regard to health and safety may be restricted if it creates a deleterious effect in one or both of the following two ways: 253

250. See id. at 1655-56 (noting the presence of case law favoring one religious group over another; however, the line that courts use to make this determination is unclear).

251. Infra Parts IV.A-C.

252. The test is modified from previous iterations described in Allan J. Jacobs, The Ethics of Circumcision of Male Infants, 15 IsRAEL MED. Ass'N. J. 60 (2013) and Allan J. Jacobs \& Kavita Shah Arora, Ritual Male Infant Circumcision and Human Rights, 15 AM. J. Bioethics 30 (2015). Prior versions were written from a general ethics perspective; this version is adapted to be applicable to American constitutional law. It has been modified in three important respects. First, the content of the restrictions (first prong) has been disaggregated from the constraints (second and third prongs). Second, this iteration of the test is phrased as determining what government may restrict; other iterations were phrased in terms of what government ought to permit. Finally, the test stipulates circumstances in which government is not only permitted, but also expected to restrict certain practices. This iteration was crafted to conform with the religion clauses of the First Amendment to the U.S. Constitution, and to guide lawmakers bound by those clauses. The connection between the test and the religion clauses will be discussed infra. While affirming that government has a responsibility to protect vulnerable people against severe injuries, the authors acknowledge that other societies may find a different balance between the need for such protection and the demands of faith. This is particularly true in States with established religions that contain a strong praxis component.

253. See infra notes 406-411 (discussing the tension surrounding the debate of infant circumcision and whether this practice, which is a required practice for certain religions, could also be a human rights violation). 
a. Direct effects: The practice affects children and other vulnerable members of the religious group ${ }^{254}$ (i) by creating a substantial chance of death or major disruption of a physiological function or (ii) by creating other objectively severe harmful effects, such as malnutrition or major psychological morbidity. ${ }^{255}$ If the effect is severe, the government has a constitutional obligation to limit the practice. ${ }^{256}$ Enforcing this obligation is generally the province of legislatures rather than courts, although in extraordinary cases it may be appropriate for courts to enforce this provision.

b. Indirect effects: The practice creates unreasonable burdens for (i) society as a whole or (ii) members of society outside the religious group. If the effects are severe, the government has a constitutional obligation to limit the practice. Enforcing this obligation is generally the province of legislatures rather than courts, although in extraordinary cases it may be appropriate for courts to enforce this provision.

2. LIKELIHOOD OF EFFECT: In order to constitute a basis for restricting a religious practice, the burdens, costs, risks, or harms must be actual, rather than merely hypothetical, and must not be unlikely.

3. MAGNITUDE OF EFFECT: Notwithstanding the foregoing provisions, if society tolerates harms from comparable mainstream practices that impose harms of a similar magnitude to the harms posed by the religious practice at issue, then it should not restrict that religious practice. Conversely, if a mainstream practice that imposes severe harms is forbidden, then a comparable religious practice that imposes harms of a similar magnitude should likewise not be tolerated. Legislatures should be mindful of this provision when considering religious accommodations, and courts should be active in enforcing it.

254. Henceforth collectively denoted as "children" for stylistic reasons.

255. See Jacobs \& Arora, supra note 252, at 31-32 (noting that the risks associated with infant circumcision are minimal; critics argue, however, that this irreversible procedure takes away an important decision for a person to make on his own).

256. See Levin, Rethinking Religious Minorities, supra note 1, at 1657 (discussing how religiously diverse the United States is and how this has contributed to a high level of religious tolerance in the United States). 


\section{B. Explaining the Test}

\section{The Thrust of the Test and Its Audience}

This test is intended to (1) impose consistency on the accommodation and non-accommodation of religious practices that may harm children and third parties; (2) to embody and reflect the constitutional values at stake; and (3) to provide appropriate guidelines for legislators and other officials, judges, medical practitioners, and other professionals who are confronted with the question of whether to participate in or enable religious practices at the request of their patients.

The Bases for Possible Restriction prong is designed to balance the interests of religious groups and individuals against those of in-group children and members of society at large who may be harmed by religious practices. It provides a default rule that religious practices should be respected unless they unduly interfere with the real and measurable interests of children within the religion and others outside the religious group. This embodies a healthy respect for religious liberty and the accommodationist commitments of a liberal society but also affirms an important societal duty to protect children and third parties from harms imposed upon them by others. This part of the test also provides that where the harms to children or third parties are sufficiently severe, the government has an obligation to prevent the conduct, because of the Establishment Clause concerns identified in Part III.C. ${ }^{257}$ In general, it is up to legislators and other policymakers, rather than courts, to assess risks of harm. However, as we discuss below, ${ }^{258}$ in extraordinary circumstances courts may be required to act in order to prevent the harm. This should be the case only where the risk of harm created by a practice is obvious to all and especially severe. In many (and perhaps most) such cases, though, courts will not have to undertake independent analysis of the magnitude of the risk and its tolerability because they may apply the Magnitude prong as a lodestar.

257. See supra Part III.C (discussing the issues created by not remedying the lack of uniformity with how religious accommodations are addressed).

258. See infra Part IV.C (discussing examples of how the test will be applied to required religious practices that cause harm). 
The Likelihood prong is designed to prevent abuse of the Bases for Possible Restriction by foreclosing pretextual action against religious practices as a result of supposed harms that may be hypothetical, slight, rare, or even nonexistent. As with the first prong of the test, this prong is primarily for legislators and other policymakers to enforce. In cases where those policymakers have obviously used a minimal risk of harm as a pretext to target religious practices, courts may intercede. Here again, though, courts will often have the benefit of the Magnitude prong to serve as their guidepost.

The Magnitude prong of the test also serves as a limitation on the Bases for Possible Restriction. Effectively, it captures the Supreme Court's admonition in Lukumi that society may not target religious practices for censure when it permits comparable mainstream practices, thus enforcing Free Exercise boundaries. ${ }^{259}$ In so doing, this limitation, in concert with the rest of the test, also serves four other important functions, which we introduce here because they help to explain the thrust and basic functions of the test.

First, the test, especially the Magnitude prong, offers a guideline for sorting through the Establishment Clause problem introduced supra. ${ }^{260}$ The Establishment Clause prohibits some third-party harms from being imposed by religious accommodations but permits others. ${ }^{261}$ Neither the courts nor legal scholars have offered much guidance for where the demarcating line is. ${ }^{262}$ The Magnitude prong suggests that where society has chosen to permit mainstream practices that are comparable to the religious conduct in question and that impose similar harms, the Establishment Clause is not violated. In other words, it does not constitute religious oppression or coercion for

259. See Church of Lukumi Bablu Aye v. City of Hialeah, 508 U.S. 520, 536 (1993) (finding that the ordinance targets religious animal sacrifice but allows other types of animal killings).

260. See supra Part III.C (explaining why it is problematic that religious accommodations are not treated uniformly).

261. See Levin, Rethinking Religious Minorities, supra note 1, at 1655 ("The Court has never adequately delineated the boundary between permissible religious accommodations and impermissible ones.").

262. For example, scholars have suggested that there is an Establishment Clause problem where the third-party harm is "significant" or "substantial," but these terms do little to offer practical guidance to courts. 
society to allow a religious practice that imposes the same kind of harm that society has generally chosen to tolerate for itself for other reasons. This evokes symmetry between the First Amendment's Free Exercise and Establishment Clauses.

Second, the test protects Free Exercise interests. The Likelihood prong prevents restriction of religious practices on frivolous grounds, and the Magnitude prong, as noted, tracks Lukumi, ${ }^{263}$ in precluding pretextual laws that functionally, but not explicitly, single out religious practices for restriction. Third, the test, taken as a whole, responds to the concerns raised by the troubling political economy dynamics discussed above. ${ }^{264}$ On the one hand, the Bases for Possible Restriction provide that religious groups cannot use their relative lobbying power in the political branches to enjoy the benefits of religious freedom while imposing the costs on the dispersed and unrepresented minority. On the other hand, the Likelihood and Magnitude prongs prevent the reverse dynamic, by prohibiting other groups-whatever their motivation-from exploiting their relative political power by granting themselves freedoms that they would not extend to religious minorities.

Finally, the test is meant to be applied by decision makers in a variety of contexts. Legislators and other officials can use it to decide prospectively how to treat a particular religious practice. Judges can use it as a baseline reference for interpreting and applying unclear legislative and administrative guidance, ${ }^{265}$ and also as a tool for making constitutional determinations as to whether the legal treatment of a religious practice violates the Free Exercise Clause or the Establishment Clause. Medical clinicians, educators, and other practitioners who do not

263. See Lukumi, 508 U.S. at 545-46 ("We conclude, in sum, that each of Hialeah's ordinances pursues the city's governmental interests only against conduct motivated by religious belief. The ordinances 'have every appearance of a prohibition that society is prepared to impose upon [Santeria worshippers] but not upon itself." (quoting Florida Star v. B.J.F., 491 U.S. 524, 542 (1989) (Scalia, J., concurring in part and concurring in judgment))).

264. See supra Part III (discussing why the way religious accommodations are granted in the United States is troubling).

265. For example, "best interests of the child," open-textured statutory provisions like RFRA, and cases related to the provision of medical treatment over parents' objections. See supra notes 130-134 and accompanying text (discussing the protection given to religious groups under RFRA). 
formulate laws can look to the test for guidance as to whether they should accede to a patient's or client's request that they participate in a particular religious practice. ${ }^{266}$ As we have already noted, the test is flexible enough that it may apply differently in each of these different contexts due to the different institutional strengths and weaknesses of each type of decision maker.

\section{Unpacking the Test: Explanations and Definitions}

\section{a. Identifying a "Religious Practice"}

As used in the test, a "religious practice" can be either an affirmative act or an affirmative decision to refrain from an act. Religious education ${ }^{267}$ and circumcision ${ }^{268}$ are examples of affirmative acts that can constitute religious practices and support religious identity. Refusal of blood transfusion, ${ }^{269}$ conscientious objection to military service, ${ }^{270}$ and abstinence from specific food products $^{271}$ are examples of affirmative

266. For example, non-vaccination or hiring a person who will not dispense contraception. See generally Adam Sonfield, Rights vs. Responsibilities: Professional Standards and Provider Refusals, GutTMACher Inst. (Aug. 2005), https://www.guttmacher.org/pubs/tgr/08/3/gr080307.html (last visited Jan. 20, 2016) ("[P]olicymakers have engaged for decades in an ever-broadening debate over whether and in what circumstances individuals or institutions involved in the provision of health care or related services can refuse to provide services or information on moral or religious grounds.") (on file with the Washington and Lee Law Review).

267. See generally Steven M. Cohen, The Impact of Varieties of Jewish Education upon Jewish Identity: An Inter-Generational Perspective, 16 CONTEMP. JEWRY 1 (1995) (discussing how education has allowed the Jewish faith to remain culturally distinct).

268. See generally Joseph Mazor, The Child's Interests and the Case for the Permissibility of Male Infant Circumcision, 39 J. MED ETHICs 421, 426-27 (2013) (discussing the religious practice of circumcision of male children).

269. See Donald T. Ridley, Jehovah's Witnesses' Refusal of Blood: Obedience to Scripture and Religious Conscience, 25 J. MED. ETHICs 469, 469-70 (1999) (explaining the Jehovah's Witnesses' objection to blood transfusion).

270. See Alfred J. Sciarrino \& Kenneth L. Deutsch, Conscientious Objection to War: Heroes to Human Shields, 18 B.Y.U. J. PUB. L. 59, 80-81 (2003) (documenting that Quakers do not serve in the military).

271. See Stephen F. Rosenthal, Food for Thought: Kosher Fraud Laws and the Religion Clauses of the First Amendment, 65 GEo. WASH. L. REV. 951, 953 
renunciations that also can be central to religious identity. ${ }^{272}$ Endogamy ${ }^{273}$ and refusal to abandon religion-specific garb in certain public areas ${ }^{274}$ display aspects of each. In all these cases, the religious person does something or refrains from doing something because of religious claims. ${ }^{275}$ Thus, religious practices go well beyond beliefs and ceremonies. ${ }^{276}$

\section{b. Identifying a "Religious Group"}

Typically, religious groups that are subject to our proposed test will be minority religious groups, for three reasons. First, every religious group in the United States constitutes a minority group. ${ }^{277}$ That is, there is no single religious sect that counts as adherents more than $50 \%$ of the population. ${ }^{278}$ Second, to the extent that mainstream Christianity places demands on religious

(1997) (explaining the Jewish dietary practices and which foods the Jewish laws prohibit).

272. See Lanse Minkler \& Metin Cosgel, Religious Identity and Consumption 5 (Univ. of Conn. Dep't of Econ., Working Paper No. 5, 2004) ("A religious commitment is often at the core of an individual's sense of identity."), http://digitalcommons.uconn.edu/cgi/viewcontent.cgi?article=1118\&context=econ -wpapers.

273. See M. Christian Green, Religion, Family Law, and Recognition of Identity in Nigeria, 25 EMORY INT'L L. REV. 945, 957-58 (2011) (documenting the rates of religious endogamy in different countries); Farrah Ahmed, Personal Autonomy and the Option of Religious Law, 24 INT. J.L., PoL'Y \& FAM. 222, 225 (2010) (discussing issues involved with the religious forms of marriage).

274. See Roberta Medda-Windischer, The Contribution of the European Court of Human Rights to the Accommodation of Contemporary Religious Diversity, 9 Eur. Y.B. MinoRity Issues 453, 460 (2010) ("For instance, what is likely to cause substantial offence to persons of a particular religious persuasion will vary significantly from time to time and from place to place, especially in an era characterised by an ever growing array of faiths and denominations.").

275. See Mazor, supra note 268, at 421 (discussing the role that circumcision plays in the Jewish faith).

276. See id. (exploring the freedom-of-choice concerns that are raised by the Jewish practice of infant circumcision).

277. See Religious Landscape Study, PEW RESEARCH CTR., http://www. pewforum.org/religious-landscape-study/ (last visited Jan. 15, 2015) (showing that no sect within a religious group in the United States constitutes more than $50 \%$ of the population) (on file with the Washington and Lee Law Review).

278. See id. (listing the percentages of the different religious groups in the United States). 
practices, they tend to be compatible with mainstream behavior, and are therefore likely to be untroubling to most. For example, American laws against selling horse meat ${ }^{279}$ or nudity ${ }^{280}$ are unlikely to trouble many people. However, immigrants from a nation in Central Asia where consumption of equine meat and dairy products is a major part of the diet ${ }^{281}$ might be bothered by the unavailability of their accustomed dishes. Third, to the extent that popular and mainstream religious groups do face barriers to performing religious practices, they are unlikely to conflict often with state law or to be perceived by the state as being inherently dangerous. After all, mainstream practice typically corresponds with social acceptability. ${ }^{282}$

For these reasons, the test will most often apply to the practices of insular groups that operate outside of, or on the margins of, the broader society. Chasidic ${ }^{283}$ Jews, for example, attempt to isolate themselves from the larger society and observe a markedly different lifestyle from most Americans. ${ }^{284}$ Chasidim "lead lives of intense piety," 285 attempting to follow and exceed

279. See Cavel Int'l, Inc. v. Madigan, 500 F.3d 551, 557-59 (7th Cir. 2007) (upholding law that banned the slaughter of horse meat for human consumption).

280. See City of Erie v. Pap's A.M. 529 U.S. 277, 296-97 (upholding city ordinance that banned nudity in public places).

281. See Kazakh National Cuisine, VISIT KAZAKHSTAN, http://visit kazakhstan.kz/en/about/80/ (last visited Feb. 29, 2016) (describing a traditional Kazakh dish made out of horse meat) (on file with the Washington \& Lee Law Review).

282. See Levin, Rethinking Religious Minorities, supra note 1, at 1647 (explaining that mainstream religions rarely need accommodations because their interests are usually reflected in the law).

283. Chasidut (חסידות) is a Hebrew word that incorporates piety and kindness. It, or Chasidism (its English equivalent), also applies to a movement in traditional Judaism. A Jew who follows Chasidism is called a Chasid (plural, Chasidim). The "Ch" in these words is guttural not found in English, pronounced like the Spanish "j."

284. See Judith Lynn Failer, The Draw and Drawbacks of Religious Enclaves in a Constitutional Democracy: Hasidic Public Schools in Kiryas Joel, 72 IND. L.J. 383, 387 (1997) ("[E]ven though Jewish law does not require Jews to live apart from non-Jews or to eschew modern conveniences, many Hasidic Jews assume the responsibilities of these additional requirements in order to ensure that they are living as holy a life as they can.").

285. See id. at 386-87 (citations omitted) (explaining that Orthodox Jews believe that if they do not follow all Jewish laws then they will face unfavorable consequences). 
the demands of Jewish orthodoxy. ${ }^{286}$ Their communities are led by a rebbe ${ }^{287}$ believed to have special awareness of God. ${ }^{288}$ Acceptable food and clothing choices are narrow. ${ }^{289}$ Marriages are endogamous and arranged. ${ }^{290}$ Chasidim consult the rebbe before they "marry, choose an occupation, settle in a neighborhood or undergo surgery or infertility treatments," 291 and before other important personal decisions. ${ }^{292}$ Religious dictates, as interpreted by the rebbe in each individual case, would even determine when they would report a crime to the authorities. ${ }^{293}$ As M. Herbert Danziger says, "Traditionalists [such as Chasidim] allow their leaders authority in political and personal matters, and the leadership attempts to exercise authority beyond the specifics of halakhah [Jewish law]." ${ }^{294}$ Chasidic Jews are at an extreme in

286. See id. at 387 (explaining that Orthodox Jews live their lives in isolation, to ensure that they do not accidentally break any Jewish laws).

287. Yiddish רבי pronounced "reb'-buh;" often translated as "grand rabbi."

288. See Failer, supra note 284, at 387-88 (explaining the influential role the Rebbe plays in the Jewish religion).

289. See id. at 387 ("In his excellent study of Hasidic Jews, Jerome R. Mintz notes, '[t]o protect the community from contaminating offenses, the Hasidim post additional strictures as a protective buffer to the law. These may be precepts regarding clothing, customs, diet, and the separation of the sexes." (citation omitted)).

290. See Steven H. Resnicoff, Jewish Law and the Tragedy of Sexual Abuse of Children-The Dilemma Within the Orthodox Jewish Community, 13 RUTGERS J. L. \& RELIGION 281, 330-31 (2012) (discussing the process of becoming married under Jewish law).

291. See Joseph Berger, Are Liberal Jewish Voters a Thing of the Past?, N.Y. TIMES (Sept. 13, 2014), http://www.nytimes.com/2014/09/14/sunday-review/areliberal-jewish-voters-athing-of-the-past.html (last visited Jan. 18, 2016) ("Yet Hasidim need to be better understood, not just because of their numbers but also because of their tendency to vote in blocs according to the wishes of a sect's grand rabbi, who often makes his choices based on pragmatic rather than ideological reasons.") (on file with the Washington and Lee Law Review).

292. See Failer, supra note 284, at 387-88 (explaining the influence of the Rebbe in the Jewish religion and how Jews make important life decisions in accordance with the views of the Rebbe).

293. See Resnicoff, supra note 290, at 355 (discussing the likelihood of Orthodox Jews consulting their rabbinic authority as opposed to non-Orthodox Jews).

294. See M. Herbert Danzger, Returning to Tradition: The Contemporary Revival of Orthodox Judaism 164 (Yale Univ. Press, 1989) (explaining that traditionalists seek guidance for their leader for matters beyond Jewish law but that modernists limit the guidance they receive from their leader to matters specific to Jewish Law). 
religious separation from society in the United States, though they are not alone. ${ }^{295}$ Protestant communities such as the Amish and Hutterites, as well as Catholic monastic communities, are comparably isolated by dress and behavior from the general population. ${ }^{296}$

That said, some conflicts between more integrated religious groups and state law do arise. 297 Many doxis-oriented mainstream religious groups that are well integrated into the broader society impose at least some prohibitions on conduct. ${ }^{298}$ For example, some mainstream Christian faiths prohibit abortion, and upholding this prohibition may, in some cases, conflict with some state-imposed obligations. ${ }^{299}$ Quakers will not swear oaths or fight in the armed forces, ${ }^{300}$ while Christian Scientists prefer not to use medical care; ${ }^{301}$ but most are otherwise undistinguishable from their neighbors. Reform Jews are also well integrated, ${ }^{302}$ placing few unique demands on their

295. See Gabriel Rauterberg, The Treatment of Isolationist Minorities, 22 YALE J.L. \& HumAn. 105, 112 (2010) ("In North America today, there are religious minorities that withdraw from the dominant society and seek to create radically different ways of life.").

296. See id. at 112-20 (discussing the different cultures and legal treatment of the Hutterites and Amish).

297. See Douglas Laycock, Regulatory Exemptions of Religious Behavior and the Original Understanding of the Establishment Clause, 81 NoTRE DAME L. REV. 1793, 1814-15 (2006) ("And Quakers were unwilling to conscript others while exempting themselves; the Franklin-drafted preamble recited that such a law would be 'inconsistent and partial,' and many Quaker legislators appear to have believed that voting to conscript anyone would violate their conscience.").

298. See Deborah Abbott \& Stephen Gottschalk, The Christian Science Tradition: Religious Beliefs and Healthcare Decisions, PARK RIDGE CTR. FOR THE STUDY OF HEALTh, FAITH \& ETHICS 1-3 (2002), http://www.che.org/members/ ethics/docs/1276/Christian\%20Science.pdf (discussing the healing process that Christian Scientists believe in).

299. See Burwell v. Hobby Lobby Stores, Inc., 134 S. Ct. 2751, 2785 (2014) ("The contraceptive mandate, as applied to closely held corporations, violates RFRA.”).

300. See Laycock, supra note 297, at 1803 (discussing the Quakers' refusal to take oaths or serve in the military).

301. See Abbott \& Gottschalk, supra note 298, at 1, 2-4 (explaining Christian Scientists' beliefs about illness and healing).

302. Half are married to non-Jews, $61 \%$ of adults are college educated, and $29 \%$ live in households with an income over $\$ 150,000$. A Portrait of Jewish Americans, PEW RESEARCH CTR. 1, 35-46 (2013), http://www.pewforum.org/files/ 2013/10/jewish-american-full-report-for-web.pdf. 
neighbors, save for the need to celebrate certain religious holidays and the preservation of infant circumcision. ${ }^{303}$

The secular liberal state, then, is routinely confronted by groups within the state whose members, collectively and individually, not only prioritize their transcendental beliefs over commitment to the state and its institutions, but in fact experience conflicts with societal norms laws. ${ }^{304}$ Thus, although more conflicts (in magnitude and in number) are likely to arise with respect to the practices of small and marginal religious groups, ${ }^{305}$ the test we propose may apply to any religious group, no matter what its size or popularity.

In deciding whether there exists a religious group that has religious claims mandating variant practices, we must look to a group's self-definition. ${ }^{306}$ Mistaken attempts by outsiders to define a religious group in order to characterize its beliefs could lead to injustice and are clearly prohibited by the Supreme Court's Establishment Clause jurisprudence. For example, one cannot look at practices of "Jews" as a single group to evaluate the validity of claims regarding the centrality of circumcision by,

303. See B'rit Milah: The Circumcision Ritual, REFORM JUDAISM, http://www.reformjudaism.org/brit-milah-circumcision-ritual (last visited July 6, 2015) (explaining the Jewish ritual of infant circumcision) (on file with Washington and Lee Law Review); The Jewish Calendar, REFoRM JudAISM, http://www.reformjudaism.org/brit-milah-circumcision-ritual (last visited July 6, 2015) (describing the Jewish calendar and providing information about each holiday) (on file with Washington and Lee Law Review).

304. See supra notes 299-301 and accompanying text (discussing examples of groups prioritizing their religious beliefs over societal norms and state commitments such as contraceptive mandates and modern medicine).

305. See supra note 282 and accompanying text (explaining that "a mainstream practice typically corresponds with social acceptability," which supports the notion that conflicts are more likely where the religious group is small or marginal and thus not widely accepted by society).

306. See Hosanna-Tabor Evangelical Lutheran Church \& Sch. v. EEOC, 132 S. Ct. 694, 706 (2012) (explaining a religious group has the "right to shape its own faith and mission"); Thomas v. Review Bd. of the Ind. Emp't Sec. Div., 450 U.S. 707, 714 (1981) (noting that the Free Exercise Clause protects all religious beliefs, even beliefs that others cannot comprehend); Richard W. Garnett, Do Churches Matter? Towards an Institutional Understanding of the Religion Clauses, 53 VILL. L. REV. 273, 295 (2008) ("[T]he existence and independence of religious institutions-self-defining, self-governing, self-directing institutionsare needed ... to "check the encroachments of secular power and preserve [the] immunities' of our 'basic human things." (citation omitted)). 
for example, Reform Judaism, which supports it, ${ }^{307}$ or the small Humanistic Jewish movement, for which infant circumcision is optional. ${ }^{308}$ Neither can one examine "Christians" as a totality to decide whether Quakers are obliged to refrain from swearing oaths. ${ }^{309}$

It is reasonable for the state to test the sincerity of claimant's religious belief, but the state may not judge one person's claims by comparison to those espoused by other members, or even leaders, of the same faith. ${ }^{310}$ For example, if a group identifying itself as the "Blue Jews" claimed draft exemption on the basis of a heterodox scriptural interpretation ${ }^{311}$ that required that they wear only blue clothes, it would be reasonable for the government to determine whether this was a sincere belief. It would be inappropriate, however, for the government to deem that this group's belief was not Jewish. ${ }^{312}$

307. See Resolution on Anti-Circumcision Initiative, UNION FOR REFORM JUDAISM (June 13, 2011), http://urj.org/about/union/governance/reso/?syspage= article\&item_id $=68500$ (last visited Feb. 12, 2016) (stating that infant male circumcision is "an integral part of the divine covenant (brit milah) that has existed for five thousand years between God and the Jewish people" and "a central religious ritual") (on file with Washington and Lee Law Review).

308. See, e.g., Statement on Circumcision and Jewish Identity, ORAYNU CONGREGATION, http://www.oraynu.org/about-us/philosophy/statement-oncircumcision-and-jewish-identity/ (last visited Feb. 12, 2016) ("We welcome into the Jewish community all who identify with the history, culture and fate of the Jewish people. Circumcision is not required for Jewish identity.") (on file with Washington and Lee Law Review).

309. See James Bradley Thayer, A Chapter of Legal History in Massachusetts, 9 HARV. L. REV. 1, 3-5 (1895) (discussing Quakers and whether they have to take an oath); Steve Sheppard, What Oaths Meant to the Framers' Generation: A Preliminary Sketch, 2009 CARdozo L. REv. De Novo 273, 279 (2009) (explaining the meaning of an oath and whether Quakers could take the oath).

310. See United States v. Seeger 380 U.S. 163, 185 (1965) ("But we hasten to emphasize that while the 'truth' of a belief is not open to question, there remains the significant question whether it is 'truly held."'); United States v. Ballard, 322 U.S. 78, 88-90 (1944) (Stone, J., dissenting) (arguing that the jury correctly found that the petitioners did not honestly believe religious experiences had occurred).

311. See Numbers 15:38 ("Speak to the Israelites and say to them: "Throughout the generations to come you are to make tassels on the corners of your garments, with a blue cord on each tassel."').

312. See Seeger, 380 U.S. at 185 (emphasizing that "the truth of a belief is not open to question" by the government or any other party). The term "group" here may be misleading, because in the United States, even a single individual's 
Finally, American law does not even require membership in a recognized religious group at all for a person to enjoy religious freedom. ${ }^{313}$ In fact, laws that give special accommodations to only "recognized" religious groups are struck down as unconstitutional under the Establishment Clause. ${ }^{314}$ To be sure, people who profess idiosyncratic religious beliefs present a significant challenge to the legal system. ${ }^{315}$ Policymakers will often be unaware of a generally applicable law's potential conflict with the beliefs and practices of such a person and so will be unable to consider whether to make such an accommodation. ${ }^{316}$ Moreover, there is a greater concern that professed idiosyncratic beliefs may not be truly sincere - and that they therefore may be adopted principally as a "cover" for a person's non-religious preferencesthan there is when it comes to recognized religious

idiosyncratic religious beliefs generally are treated as deserving of the same legal protection as those of more recognized groups. It may be easier for a group with a long history, canonical texts, a well-established hermeneutic tradition, a large membership, formal rules, and sources of authority to demonstrate sincerity than for a single individual to do so. However, these should not be dispositive. It is also reasonable to ask whether a religious rationale is pretextual whether the religion in question has one adherent or millions.

313. See U.S. Const. amend. I ("Congress shall make no law respecting an establishment of religion, or prohibiting the free exercise thereof . ..."); Frazee v. Ill. Dep't of Emp't Sec., 489 U.S. 829, 834 (asserting that a personal religious faith is "entitled to as much protection as one espoused by an organized group").

314. See Everson v. Bd. of Educ. of Ewing Township, 330 U.S. 1, 15 (1947) ("The establishment of religion clause of the First Amendment means at least this: Neither a state nor the Federal Government can set up a church. Neither can pass laws which aid one religion, aid all religions, or prefer one religion over another.”); McCarthy v. Boozman, 212 F. Supp. 2d 945, 950 (2002) (striking down an Arkansas statute that required applicants for religious exemptions to vaccinations to belong to a "recognized religious organization" that opposed vaccination as a violation of the First and Fourteenth Amendments).

315. See Vinning-El v. Evans, 657 F.3d 591, 593-95 (7th Cir. 2011) (discussing a prison inmate's belief that his interpretation of the Moorish Tenants of America and the State's conflict as to whether his idiosyncratic interpretation of the religion's established practices were constitutionally protected, and holding that the inmate was entitled to protection if he could prove his beliefs were sincere).

316. See Eugene Volokh, A Common-Law Model for Religious Exemptions, 46 UCLA L. REV. 1465, 1524 (1999) (posing an example of an employer with idiosyncratic religious beliefs that conflict with a generally-applicable minimum wage mandate, and discussing the potential for a common-law exemption regime as opposed to a regime where those beliefs go unnoticed by policymakers). 
communities. ${ }^{317}$ Strictly speaking, though, membership in a recognized religious group is not a prerequisite for religious freedom claimants. ${ }^{318}$

\section{c. The Types of Risks, Burdens, Harms, and Costs Contemplated by the Test}

Although the test and our discussion uses the terms risks, burdens, harms, and costs in variety, as appropriate for the particular issue, we generally recognize that these terms are often interchangeable.

The burdens on society at large or on non-members of the religious group contemplated by the Indirect Effects basis obviously can include health- and safety-related concerns. ${ }^{319}$ For instance, refusal to vaccinate a child directly jeopardizes those outside a religion who are unable to be vaccinated successfully. ${ }^{320}$ Likewise, whether a state may ban a Sikh from carrying his kirpan (ceremonial dagger) to school also relates to health and safety concerns. ${ }^{321}$ However, the Indirect Effects prong also might

317. See supra note 310 and accompanying text (discussing the constitutionality of testing the "sincerity" of a party's religious beliefs, and examining the Ballard and Seeger holdings where proper methods and limitations on this testing were discussed); see also Vinning-El, 657 F.3d at 595 (exploring the concern of the state and courts over whether an individual's idiosyncratic religious mandate was "sincerely held" and allowing that test to go to a jury).

318. See supra note 313 and accompanying text (demonstrating the law's considerable protection for individual religious freedom claims).

319. See supra Part IV.A.1.b (discussing the operation of the "Indirect Effects" basis of the test, and that where a practice "creates unreasonable burdens for (i) society as a whole or (ii) members of society outside the religious group," the government "has a constitutional obligation to limit the practice").

320. See Daniel A Salmon et al., Compulsory Vaccination and Conscientious or Philosophical Exemptions: Past, Present, and Future, 367 LANCET 436, 436 (2006) (explaining the danger presented to members of society who cannot obtain a successful vaccination by exposure to a child who is not vaccinated for religious reasons, but could have been otherwise). We discuss the issue of in greater detail infra Part IV.C.2.

321. Without taking a position as to whether this practice may (or should) be outlawed under our proposed test, we note that the Canadian Supreme Court allowed the practice, deciding that the kirpan posed minimal risk to other children. See Multani v. Comm'n scolair Marguerite-Bourgeoys, 1 S.C.R. 6 (2006) (finding that the Orthodox Sikh's religious freedom had been infringed); 
apply to cases that do not involve concerns of health or safety, but rather the imposition of substantial material or financial costs on society. ${ }^{322}$ For instance, a society might choose to decline to pay for prolonged or indefinite care for a terminally ill and unconscious child who is not expected to regain consciousness because of the costs this imposes on society, both with respect to the monetary expense and the use of medical resources.

In contrast, the Direct Effects prong, which seeks to protect the children of the religious group from harmful religious practices directed at them, contemplates only major health (physical and psychological) and safety-related harms. ${ }^{323}$ General standards of medical ethics and the laws of most jurisdictions recognize the best interests of the child as a key factor for determining how best legally to protect a child. ${ }^{324}$ All U.S. jurisdictions recognize this standard as determinative with regard to custody cases. ${ }^{325}$ The best interest standard is poorly

see also Shaheen Shariff, Balancing Competing Rights: A Stakeholder Model for Democratic Schools, 29 CAN. J. EDUC. 476, 481-89 (2006) (discussing the social implications of the Multani holding).

322. For example, the daily cost of caring for a patient in a pediatric intensive care unit from 2004 to 2007 was $\$ 3,565$. See Jeffrey D. Edwards, Chris Rivanis, Sheila S. Kun, Aaron B. Caughey \& Thomas G. Keens, Costs of Hospitalized Ventilator-Dependent Children: Differences Between a Ventilator Ward and Intensive Care Unit, 46 PEDIATRIC Pulmonology 356, 356-61 (2011). If a minority practice incurred large volumes of such care, the Indirect Care prong might be invoked.

323. See supra Part IV.A.1.a (introducing the "Direct Effects" prong and explaining that if the practice affects children by creating a "substantial chance of death or major disruption of a physiological function" or other "severe harmful effects, such as malnutrition or major psychological morbidity," then the government has a constitutional obligation to limit it).

324. See Tom L. Beauchamp, Methods \& Principles in Biomedical Ethics, 29 J. MeD. Ethics 269, 269-70 (2003)

Well before autonomy and privacy were pervasively applied through law and morals to the decisions of surrogates for incompetents and minors, the best interests standard-rather than an autonomy standard-was recognized as having authority over parental rights. It is the fitting standard for analysis of the case before us. The best interests standard validly overrides parental rights of control whenever the welfare interest of the child is substantial. If the interests of the child were less than substantial-for example, if the outcome of a surgical intervention had merely the effect of an unobtrusive scar-then deference to parental wishes would be reasonable.

325. Julia Halloran McLaughlin, The Fundamental Truth About Best 
defined, though, and is often conclusory in practice. ${ }^{326}$ Legislation typically lays out guidelines with numerous factors and gives judges broad discretion to balance these factors in deciding individual cases. ${ }^{327}$ It is fair to say as a general matter, that in the United States "[ $t$ ]he best interests of the child are served by a parenting arrangement that best maintains a child's emotional

Interests, 54 ST. LOUIS U. L.J. 113, 117 (2009) ("State legislatures have universally adopted the BICS [Best Interests of the Child Standard] and applied it to determine custody and visitation disputes.").

326. See Sylvia A. Law \& Patricia Hennessey, Is the Law Male?: The Case of Family Law, 69 CHI.-KenT L. REV. 345, 350 (1993) (arguing that the "best interest" standard is vague and uncertain and result in conclusory judgments by the trial court judges).

327. See, e.g., Conn. Gen. STAT. § 46b-56 (2013)

[T]he court shall consider the best interests of the child, and in doing so may consider, but shall not be limited to, one or more of the following factors: (1) The temperament and developmental needs of the child; (2) the capacity and the disposition of the parents to understand and meet the needs of the child; (3) any relevant and material information obtained from the child, including the informed preferences of the child; (4) the wishes of the child's parents as to custody; (5) the past and current interaction and relationship of the child with each parent, the child's siblings and any other person who may significantly affect the best interests of the child; (6) the willingness and ability of each parent to facilitate and encourage such continuing parent-child relationship between the child and the other parent as is appropriate, including compliance with any court orders; (7) any manipulation by or coercive behavior of the parents in an effort to involve the child in the parents' dispute; (8) the ability of each parent to be actively involved in the life of the child; (9) the child's adjustment to his or her home, school and community environments; (10) the length of time that the child has lived in a stable and satisfactory environment and the desirability of maintaining continuity in such environment . . ; (11) the stability of the child's existing or proposed residences, or both; (12) the mental and physical health of all individuals involved... except that a disability of a proposed custodial parent or other party, in and of itself, shall not be determinative of custody unless the proposed custodial arrangement is not in the best interests of the child; (13) the child's cultural background; (14) the effect on the child of the actions of an abuser, if any domestic violence has occurred between the parents or between a parent and another individual or the child; (15) whether the child or a sibling of the child has been abused or neglected...; and (16) whether the party satisfactorily completed participation in a parenting education program ... The court is not required to assign any weight to any of the factors that it considers.

(emphasis added). 
growth, health and stability, and physical care." 328 The best interests of the child are, however, balanced in most jurisdictions against "a parent's constitutionally protected right to raise a child and maintain a relationship with that child, without undue interference by the state." ${ }^{2} 29$ Not only do parents have rights, but there is a rebuttable presumption that parental decisions are in the child's best interest. ${ }^{330}$

Dangerous practices that can subject a child to the possibility of death can include withholding transfusion, ${ }^{331}$ withholding other forms of medical care, ${ }^{332}$ or sacramental venomous snake handling. ${ }^{333}$ Some practices may not endanger life, but create a

328. In re Parentage of L.B., 122 P.3d 161, 172 (Wash. 2005) (quoting WASH. REV. CODE $§ 26.09 .002$ (2007)).

329. N.J. Dep't of Children \& Families, Div. of Youth and Family Servs. v. A.L., 59 A.3d 576, 585 (N.J. 2013) (quoting N.J. Div. of Youth \& Family Servs. v. E.P., 952 A.2d 436, 444 (N.J. 2008)); see Pierce v. Soc'y of Sisters, 268 U.S. 510, 534-35 (1925) (holding that parents have the liberty to direct the upbringing and education of their children); Meyer v. Nebraska, 262 U.S. 390, 400 (1923) (stating that it is the natural duty of the parents to give their children suitable education).

330. See Troxel v. Granville, 530 U.S 57, 68-69 (2000) (explaining that there is usually no reason for the State to get involved in family issues as long as the parent adequately cares for his or her children).

331. See In re McCauley, 565 N.E.2d 411, 412 (Mass. 1991) (explaining that parents who were Jehovah's Witnesses refused to consent to blood transfusions for their daughter); State v. Perricone, 181 A.2d 751, 753 (N.J. 1962) (stating that parents who were Jehovah's Witnesses refused to grant permission for their son to get a necessary blood transfusion).

332. See State v. Neumann, 832 N.W.2d 560, 591 (Wis. 2013) (ruling that prosecuting parents for reckless homicide because they did not seek medical treatment for their child did not violate the parents' free exercise rights); Walker v. Superior Court, 763 P.2d. 852, 855 (Cal. 1988) (concluding that prosecution is permitted against a mother whose child died after receiving prayer instead of medical treatment).

333. See Mary L. Daugherty, Serpent-Handling as Sacrament, 33 Theology TODAY 232, 232 (1976) ("For many years mountain people have suffered terrible pain and many have died from snake bite. Small wonder that it is considered the ultimate act of faith to reach out and take up the serpent."). Daugherty states that children do not handle snakes. See id. at 241 ("Children are kept far away."). However, others claim that children may occasionally participate in these rituals. See Steven M. Kane, Holy Ghost People: The Snake-Handlers of Southern Appalachia, 1 APPALACHIAN J. 255, 260 (1974) ("Although devotees report that children as young as six have handled snakes, I have not observed any person younger than nineteen do so."). There are documented incidents over seventy years old of children handling snakes at religious services. See Michael J. McVicar, Take Away the Serpents from Us: The Sign of Serpent Handling and 
substantial chance of major physiological disruption. For example, the obsolete Chinese practice of binding the feet of girls $^{334}$ can sufficiently limit locomotion that it could be banned under this justification. Extensive female genital alterations that make sex painful or vaginal delivery dangerous ${ }^{335}$ also could be banned on this basis.

The Direct Effects provision also allows for the restriction of a religious practice if it causes other kinds of objectively severe harmful effects to a child of the religious group. ${ }^{336}$ Here, too, we focus on health and safety concerns, but it is critical to note that psychological impairment can be sufficient to constitute such harm. ${ }^{337}$ These could be, for example, major psychological morbidity or physical mutilation that would reduce a child's

the Development of Southern Pentecostalism, 15 J. S. RELIGION (2013) (discussing the rise of serpent-handling and "holiness worship" beginning in the 1930s).

334. See Yuhui Li, Women's Movement and Change of Women's Status in China, 1 J. INT'L Women's STUD. 30, 30 (2000) (explaining the practice of foot-binding).

335. See Utz-Billing \& Kentenich, supra note 6, at 227 (giving an overview of vaginal alteration procedures and discussing negative consequences relating to health and reproduction); S.H.A. Andersson et al., Sexual Quality of Life in Women Who Have Undergone Female Genital Mutilation: A Case-Control Study, 119 InT'L J. OBstetRICS \& GYNECOLOGY 1606, 1608 (2012) (discussing the painful side effects and other sexual repercussions experienced by a majority of women studied who had experienced female genitalia mutilation). But see Bergitta Essén et al., No Association Between Female Circumcision and Prolonged Labour: A Case Control Study of Immigrant Women Giving Birth in Sweden, 121 Eur. J. Obstetrics Gynecology ReProd. Biol. 182, 182-83 (2005) (comparing the labor statistics of sixty-eight African women who underwent female circumcision to 2,486 uncircumcised Swedish women and finding that the former bore a lower risk of prolonged labor); S. Wuest et al., Effects of Female Genital Mutilation on Birth Outcomes in Switzerland, 116 INT'L J. OBSTETRICS \& GYNECOLOGY 1204, 1207 (2009) (discussing study results that found a lower rate of prolonged labor and birth risks in Swedish females who underwent female genitalia mutilation, and stating that the same women under managed care did not show a propensity for higher maternal and female morbidity). See generally Taha Abd El-Naser et al., Sexual Side Effects of Female Genital Mutilation/Cutting May Be Type Dependent: A Hospital-Based Study, 1 KosR Al-Aini J. Obstetrics AND Gynecology 65, 67-72 (2010).

336. See supra Part IV.A.1.a (explaining that where "the practice affects children and other vulnerable members of the religious group ... by creating other objectively severe harmful effects," the state has an obligation to limit the practice).

337. See id. (establishing "major psychological morbidity" as an example of a sufficient harm to constitute a direct effect under the test). 
ability to function in the general society. ${ }^{338}$ Thus, even if labial reduction did not constitute a danger to a major physiological function, it nonetheless would likely cause major psychological morbidity if it were performed without anesthesia upon a non-consenting adolescent. ${ }^{339}$ It might also apply to practices that markedly limit the child's future occupational capacity; for example, permanent facial alterations such as tattooing ${ }^{340}$ or scarification $^{341}$ religious rituals, which are not often seen in the

338. To the extent that liberal pluralists accept illiberal minorities, they tend to require that there be free egress from the group - some have made this point explicitly. See, e.g., Galston, supra note 19, at 528 (arguing for enforcing prohibitions against preventing someone from leaving a group); Mark D. Rosen, The Educational Autonomy of Perfectionist Religious Groups in a Liberal State, 1 J. L., RELIGION \& ST. 16, 17 (2012) (arguing for autonomy of illiberal minorities subject to an "opt-out" constraint). Others have made it implicitly, in asserting that freedom, religion, or human rights in general must constrain acceptance for minority groups. See generally Amy Gutmann, Introduction to CHARLES TAYLOR ET AL., Multiculturalism: Examining the Politics of Recognition 10-11 (Amy Gutmann, ed. 1994); Will KymlickA, Multicultural Odysseys 92-94 (2007). This is in contrast to a regime such as the Ottoman millet system, in which members of minorities were under the jurisdiction of that community, and egress from the community was restricted. See generally Karen Barkey, Islam and Toleration: Studying the Ottoman Imperial Model, 19 INT. J. PoL., Culture, \& Soc'y 5 (2005); Timur Kuran, The Economic Ascent of the Middle East's Religious Minorities: The Role of Islamic Legal Pluralism, 33 J. LEGAL STUD. 475 (2004). Israel maintains remnants of this system, giving religious courts exclusive jurisdiction over marriage and divorce. See Yüksel Sezgin, The Israeli Millet System: Examining Legal Pluralism Through Lenses of Nation-Building and Human Rights, 43 IsR. L. REV. 631, 631 (2010) ("The millet system that Israel adopted upon its independence was a highly pluralized and decentralized legal system under which the Ottoman and British imperial authorities granted juridical autonomy over matters of personal status.").

339. See generally Arora \& Jacobs, supra note 7 (discussing ethics and policy surrounding female genital mutilation, and potential psychological impacts on non-consented operations).

340. See John Barker \& Anne Marie Tietjen, Women's Facial Tattooing Among the Maisin of Oro Province, Papua New Guinea: The Changing Significance of an Ancient Custom, 60 OcEANIA 217, 217 (1990) (describing the tradition of facial tattooing); Christian Palmer \& Mervyn L. Tano, Mokomokai: Commercialization and Desacralization, N.Z. Elec. TeXT CentRe (2007), http://www.iiirm.org/publications/Articles\%20Reports\%20Papers/ Genetics\%20and\%20Biotechnology/mokomokai.pdf (discussing the Maori culture and the practice of facial tattooing). Tattooing was a puberty ritual imbued with sacred significance. See id. ("For women of chiefly rank, tattooing was an important ceremony that accompanied puberty and marked the entry into womanhood.").

341. See, e.g., Olanike Ola Orie, The Structure and Function of Yoruba Facial Scarification, 53 ANTHROPOLOGICAL LINGUISTICS 15, 15 (2011) (stating that the 
United States, ${ }^{342}$ might negatively affect a child's social acceptability and employability. ${ }^{343}$ Therefore, although ritual tattooing and scarification have no major physiological effect, a liberal society might be justified in prohibiting them under this provision.

\section{d. The Likelihood of Burdens Associated with the Test}

The test, through the Likelihood prong, addresses whether the religious practice imposes substantial risk of direct or indirect harms. ${ }^{344}$ It could not be otherwise, for it is often impossible to say with certainty whether the withholding of a particular medical treatment-or, even more obviously, of a vaccinationwill cause an actual harm to a specific individual. ${ }^{345}$ Society may still choose to protect itself and children of the religious group from the increased risk of harm imposed by the religious practice. ${ }^{346}$

Yoruba etched identification marks into their faces).

342. But see Jana C. Saunders \& Myrna L. Armstrong, Experiences and Influences of Women with Cosmetic Tattooing, 17 DERMATALOGICAL NuRSING 23, 23 (2005) (discussing tattooing procedures performed for exclusively aesthetic reasons in some developed cultures).

343. See Randy K. Chiu \& Richard D. Babcock, The Relative Importance of Facial Attractiveness and Gender in Hong Kong Selection Decisions, 13 INT. J. Hum. Resource MGMT. 141, 141 (2002) ("This field experiment found that Hong Kong human resources management specialists were influenced by the attractiveness bias in evaluating short-listed candidates for an entry-level trainee position."); Marlene Rankin \& Gregory L. Borah, Perceived Functional Impact of Abnormal Facial Appearance, 111 Plastic ReCONSTRUCTIVE SURGERY 2140,2140 (2003) ("The purpose of this study was to establish a large, sample-based evaluation of the perceived social functioning, interpersonal characteristics, and employability indices for a range of facial appearances (normal and abnormal).").

344. See supra Part IV.A.2 ("In order to constitute a basis for restricting a religious practice, the burdens, costs, risks, or harms must be actual, rather than merely hypothetical, and must not be unlikely.").

345. See, e.g., Harrison v. Tauheed, 235 P.3d 547, 557 (Kan. App. 2010) (evaluating whether it was important to determine actual harm to the individual in applying a standard of review to religious beliefs and practices of a parent applying for custody of their child).

346. See Harriet Hall, Faith Healing: Religious Freedom vs. Child Protection, SCIENCE-BASED MED. (Nov. 19, 2013), https://www.science basedmedicine.org/faith-healing-religious-freedom-vs-child-protection/ (last visited Jan. 21, 2016) (discussing various religious exercises that have denied children 
The issue of "risk of harm" is hardly a novel one in the law; courts have long had to deal with environmental hazards and product safety cases in which plaintiffs seek relief based on the risk of harm, rather than on an actual occurrence. ${ }^{347}$ The question in these cases is whether a risk is sufficiently great to provide the plaintiff with standing to sue. This is analogous to our question of whether a risk of harm is sufficiently great to allow restrictive legislation. To be considered a controversy under the current interpretation of the Cases and Controversies Clause of the Constitution, ${ }^{348}$ a claim must allege injuries that are "(a) concrete and particularized, and (b) actual or imminent, not conjectural or hypothetical." ${ }^{449}$ We suggest a similar, though perhaps slightly broader, approach to the question of risk in our test. ${ }^{350}$

Thus, as the Likelihood prong clarifies, the risk of harm must be actual, rather than merely hypothetical, and it may not be unlikely. ${ }^{351}$ That is, the nature of the injury must be known, and although it is not necessary to identify the specific individuals who will suffer the injury, it is sufficient to identify a reasonably increased risk of injury. ${ }^{352}$ In other words, there is an inchoate

medical treatments or care, and certain actions by states an social groups to limit these religious exercises where the danger to children is too great) (on file with the Washington and Lee Law Review).

347. See, e.g., Birdsong v. Apple, Inc., 590 F.3d 955, 956 (9th Cir. 2009) (explaining that the plaintiff brought suit because Apple's iPod posed a risk of hearing loss); Comm. to Save the Rio Hondo v. Lucero, 102 F.3d 445, 449 (10th Cir. 1996) (requiring a litigant to show an increased risk in environmental harm).

348. See U.S. Const. art. III, § 2, cl. 1 (limiting the jurisdiction of federal courts established by Article III to certain "cases" and "controversies" mostly involving the United States or a state as a party, or cases arising under the Constitution or an international treaty).

349. Bennett v. Spear, 520 U.S. 154, 162 (1997) (citing Lujan v. Defenders of Wildlife, 504 U.S. 555, 560-61 (1992)).

350. Current standing doctrine appears to not consider increased risk if it is broadly shared throughout society and not specifically focused on an individual person. See F. Andrew Hessick, Probalistic Standing, 106 Nw. L. REv. 55, 67 (2012) (discussing the development of the "probabilistic standing" doctrine, which places less emphasis on increased risk where an individual claimant is not the sole focus). Our conception for the purpose of our test is slightly broader.

351. See supra note 344 and accompanying text (defining the scope and operation of the Likelihood prong).

352. See, e.g., Sutton v. St. Jude Med. S.C., Inc., 419 F.3d 568, 570-75 (6th 
class of individuals who definitely will suffer harm, and the nature of the harm can be identified, but the identity of those individuals within the group who will experience the harm cannot be known in advance. ${ }^{353}$ That said, the degree to which a risk becomes intolerable for society and thus that it becomes defensible for a practice to be prohibited is uncertain, subject to reasonable disagreement, requires the application of judgment, and is typically the province of legislators and other policymakers.

Consider, for example, a hypothetical religion that initiates children using baptism by immersion in water at the age of four. The state proposes to abolish this practice because it might create phobias with regard to water and because a convincing scientific model shows a risk of death due to the shock of the immersion of 1 in 4 billion. ${ }^{354}$ Neither of these justifications passes muster under our test; the notion that a practice "might" create phobias is a hypothesized, rather than an actual harm, and a risk of death of 1 in 4 billion surely qualifies as unlikely. ${ }^{355}$

Cir. 2005) (deciding that there is standing based upon an increased risk of future harm); Covington v. Jefferson Cty., 358 F.3d 626, 639 (9th Cir. 2004) (stating that the question for injury-in-fact is whether the defendant's actions caused reasonable concern of injury); Baur v. Veneman, 352 F.3d 625, 628 (2d Cir. 2003) (concluding that "exposure to an enhanced risk of disease transmission may qualify as injury-in-fact”). The D.C. Circuit, which hears the bulk of appeals of challenges to regulations, rejected rare events as a basis for action. Tracking the reasoning of the D.C. Circuit, we also reject restriction based on rare or hypothetical events.

353. See Allan J. Jacobs, Is State Power to Protect Health Compatible with Substantive Due Process Rights?, 20 AnNals Health L. 113, 116 (2011) ("Second, it will characterize the beneficiaries of public health laws as those persons who would actually suffer injurious consequences from the government's failure to act. The identity of these individuals, however, often cannot be determined in advance.").

354. See Nat. Res. Def. Council v. EPA, 440 F.3d 476, 483 (D.C. Cir. 2006) (holding that a plaintiff did not have standing to sue for an injury that had a probability of 1 in 4.2 billion per person per year).

355. In addition, the Magnitude prong of the test prohibits such a ban because there is no law against taking a child of the same age into a swimming pool and quickly dunking them as part of the process of learning to swim. 


\section{e. The Magnitude Limitation: Tolerance of Harmful Mainstream Practices Requires Tolerance of Comparably Harmful Religious Practices}

To understand the limitation imposed by the Magnitude prong, consider a hypothetical case in which 50,000 Americans have settled in a non-Western nation, forming $1 \%$ of that nation's population. The Americans, seeking to maintain their cultural identity, belong to churches that sincerely believe that American football develops character traits that boys should possess. The Americans educate their children in church schools that incorporate football as an integral part of the boys' curriculum. Eventually, the number of injuries football players incur appalls the general public in the host nation, ${ }^{356}$ and it is considering criminally penalizing adults who organize football programs. The injury rate of $2 \%$ per high school game or practice, with concussions occurring once in every 300 athletic-exposures, ${ }^{357}$ may be sufficient to allow prohibition under our test. However, the inquiry does not end there; if the host society encourages its boys to box and play ice hockey, the Magnitude prong would make it impermissible to abolish football. ${ }^{358}$ In that case, the host society has a comparably dangerous sports ritual, and the ban on football would represent discrimination. ${ }^{359}$ However, a gentle nation that discourages competitive violent sports would appropriately ban football, despite the desires of participating parents and children to the contrary.

356. See generally Randall Dick et al., Descriptive Epidemiology of Collegiate Men's Football Injuries: National Collegiate Athletic Association Injury Surveillance System, 1988-1989 Through 2003-2004, 42 J. ATHLETIC Training 221 (2007) (collecting data of injuries among college football players); Prasad R. Shankar et al., Epidemiology of High School and Collegiate Football Injuries in the United States, 2005-2006, 35 AMER. J. SpORTS MED. 1295 (2007) (comparing the number of injuries between high school and college football players).

357. Shankar, supra note 356, tbl.1. An athletic exposure is a single athlete in a single competition or practice.

358. See supra Part IV.A.3 ("Notwithstanding the foregoing provisions, if society tolerates harms from comparable mainstream practices that imposes harms of a similar magnitude to the harms posed by the religious practice at issue, then it should not restrict that religious practice.").

359. See id. (applying the logic of the test's operation to this hypothetical and determining that it would treat the sports exercises as "comparable" under the Magnitude prong). 
Thus, similar to Likelihood prong, the Magnitude prong imposes constraints on the Bases for Possible Restriction, providing that in order to ban a religious practice that meets the criteria set forth in the Bases, society cannot simultaneously tolerate comparable mainstream practices-religious or not-that impose similar harms. For a realistic example, if a society tolerates infant circumcision performed by a doctor in hospitals for non-religious reasons, it must also tolerate religious Jews' practice of home infant circumcision performed by a trained mohel (Jewish circumciser) unless the risks associated with this religious practice are of greater magnitude than those associated with the non-religious practice. ${ }^{360}$

The limitation reflected in the Magnitude prong serves three functions. First, as a substantive matter, it aids policymakers and judges in identifying those religious practices that impose intolerable burdens on children and third parties under the first prong. In a vacuum, it can be difficult to determine whether the risks associated with a religious practice merit the legal sanction of the practice. ${ }^{361}$ Society tolerates and sometimes encourages harmful secular practices of all sorts, after all. ${ }^{362}$ Courts are particularly ill-suited to decide whether the risk of harm imposed by a particular practice is too great for society to bear. ${ }^{363} \mathrm{By}$ requiring policymakers, and judges in particular, to compare the religious practice in question with other comparable practices, the substantive intolerability of the religious practice would be illuminated. If society tolerates the risk for the comparable mainstream practice, then the risk is evidently not intolerable; but if it has outlawed the mainstream practice, then society has apparently already deemed the risks intolerable. In either case, it

360. See supra notes 306-308 and accompanying text (discussing the Jewish circumcision custom and issues in greater detail).

361. See Richard W. Garnett, Note, Taking Pierce Seriously: The Family, Religious Education, and Harm to Children, 76 NoTre DAME L. REV. 109, 11516 (2000) (discussing the balance between free-exercise values and protecting children).

362. See supra notes 356-357 and accompanying text (providing statistics of the dangers of playing football, a secular activity that children are often encouraged to play and is tolerated in America).

363. See Levin, Rethinking Religious Minorities, supra note 1, at 1683 (explaining why majoritarian branches should decide on religious accommodation instead of courts). 
must treat the religious practice comparably. Broadening policymakers' and judges' focus when considering a ban on a religious practice to include comparing to mainstream practices with similar sorts of risks can thereby serve as a powerful and useful heuristic for determining whether the potential harms arising from the practice are substantively intolerable.

Second, this symmetrical sorting mechanism also responds to the concerns raised by the public choice problem identified above $^{364}$ by giving policymakers and judges a principled tool for considering religious accommodations and restrictions on religious practices. Rather than relying on ad hoc determinations and the dynamics of the political marketplace, and thus empowering cohesive lobbying groups (whether pro-accommodation or pro-restriction) at the potential expense of the diffuse majority, 365 they would instead consider such individual questions in the broader context of the law. If a religious group lobbied to permit a practice that imposes harms on others that are not tolerated with respect to the analogous secular practices, that religious group would not receive the accommodation. ${ }^{366}$ At the same time, if a majority within society or a powerful non-religious lobbying group lobbies to outlaw a religious practice, the effort would be denied if society at large was unwilling to impose the same restrictions on its own similar practices. $^{367}$ In turn, this could reduce the outsize power of

364. See supra Part III.B (introducing the concept of public choice theory and discussing how implementing the test "can model the circumstances in which the political branches will underprotect and overprotect religious liberty").

365. See C. Eugene Steuerle, The Government We Deserve 59 (1998) (discussing the rise of modern cohesive lobbying strategies and how they are empowered or diffused when "complex public policies [produce] different impacts for different groups").

366. See Michael W. McConnell, Why Protect Religious Freedom?, 123 YALE L.J. 530, 531-35 (2013) (discussing several theories on why religious practices that are potentially harmful should or should not receive accommodations or be "singled out").

367. See Church of Lukumi Babalu Aye, Inc. v. City of Hialeah, 508 U.S. 520, 536 (1993) (describing a city ordinance that targets religious animal sacrifice but allows other killings, which was invalidated); Tenafly Eruv Ass'n, Inc. v. Borough of Tenafly, 309 F.3d 144, 178-79 (3d Cir. 2002) (invalidating the discriminatory enforcement of a law that required the removal of attachments to utility poles affixed by Orthodox Jewish residents but allowed other materials to be attached to the poles). 
interest group lobbying in our political system by giving voice to the diffuse majority, while at the same time encouraging religious groups and other groups to work collaboratively to find principled or mutually-satisfactory compromises that are not currently the norm in American politics. ${ }^{368}$

Third, this limitation on the ability of society to ban religious practices also helps to resolve the difficult Establishment Clause problem we have identified. ${ }^{369}$ The Supreme Court has suggested that legal tolerance or accommodation of religious practices that impose third-party harms potentially violate the Establishment Clause. ${ }^{370}$ That is, when the state's legal apparatus permits religious groups to impose costs on unwilling third parties, it is essentially permitting a kind of religious rule within society. ${ }^{371}$ On the other hand, it is also the case that society has long accommodated many religious practices that impose costs and harms on third parties; for instance, tax benefits given to religious non-profit institutions impose costs on others because they shift costs elsewhere in society. ${ }^{372}$ The longstanding practice of granting draft exemptions on the basis of religious belief harm those who must be drafted in place of those granted such exemptions. ${ }^{373}$ Yet courts have not questioned these practices under the Establishment Clause. ${ }^{374}$ And so we are left with a

368. See Robinson, Lobbying in the Shadows, supra note 174, at 1066-67 (explaining why it is currently not the norm for religious groups to compromise with others).

369. See supra Part III.C (discussing the Establishment Clause and the conflicts that arise when potentially limiting the exercise of religious practices and beliefs).

370. See Levin, Rethinking Religious Minorities, supra note 1, at 1655 (discussing the line of cases that interpret the Establishment Clause to limit the accommodation of religious practices that harm third parties).

371. See id. at 1656 (stating that "majoritarian branches are often eagerovereager, perhaps-to accommodate religious groups' interests" and concluding that the phenomenon is resulting in religious minorities somewhat dictating majoritarian public policy).

372. See supra notes 241-242 and accompanying text (discussing the Smith holding and the contrasting viewpoints on religious accommodation that spring from it).

373. See supra note 243 and accompanying text (discussing the Free Exercise Clause of the Constitution and its impact on several cases, including a military draft exemption).

374. See United States v. Seeger, 380 U.S. 163, 165 (1965) (discussing the Establishment Clause's role in adjudicating draft exemptions for religious 
difficult question: When a religious practice imposes costs and risks on third parties, how can we tell whether tolerance of that practice violates the Establishment Clause? In other words, how do we draw the line?

The Magnitude prong offers a potential means of resolving this question in many cases. ${ }^{375}$ If a society accepts similar costs when imposed on non-religious grounds, then there is no Establishment Clause violation, because society has decided that these are tolerable costs of living in that society. ${ }^{376}$ On the other hand, if society rejects these costs when imposed by non-religious practices, then it has in fact said that there is something so intolerable about the risks and harms associated with the practice that we will not allow anyone to be subjected to them. Consequently, giving legal dispensation to religious groups alone to impose such costs on others strongly suggests an Establishment Clause violation. ${ }^{377}$

Consider again the military draft exemption. ${ }^{378}$ Society has always chosen to exempt some people from the draft for a variety of reasons, thereby imposing risks and harms on others: People pursuing certain educational opportunities; ${ }^{379}$ people in certain jobs or positions of power; ${ }^{380}$ people with certain family

reasons, and framing the appellant's successful argument within its language).

375. See supra Part IV.A.3 (defining the test's Magnitude prong).

376. See Lemon v. Kurtzman, 403 U.S. 602, 612-13 (1971) (discussing the evils which the Establishment Clause aims to protect against, and tests for finding an Establishment Clause violation based upon whether "its principal or primary effect . . . neither advances nor inhibits religion").

377. See id. at 635 (Douglas, J., concurring) (using the example of a Christian schoolteacher to discuss the potential for an Establishment Clause violation where religious accommodations are used to "indoctrinate" or unfairly impose costs on society).

378. See supra note 373 and accompanying text (laying out the military draft example).

379. See Anne Yoder, Military Classifications for Draftees, SwARTHMORE COLL. PEACE COLLECTION, http://www.swarthmore.edu/library/peace/ conscientiousobjection/MilitaryClassifications.htm (last updated Mar. 2014) (last visited Feb. 12, 2016) (compiling the different classifications and exemptions for each draft statute) (on file with the Washington and Lee Law Review).

380. See id. (discussing ministerial students in category 2-D and student postponements in the notes below the latest table in the 2002 Act, as well as various student exemptions in previous iterations). 
obligations; ${ }^{381}$ people who, though physically fit and capable, age out of the draft; $; 82$ people whose draft numbers simply are not called; 383 and non-religious people with conscientious objections to military service. ${ }^{384}$ All of these people may be free from the burden of military service, thus imposing the burden of military service on others in society who do not share these criteria. ${ }^{385}$ Evidently - for better or worse-we have collectively chosen to bear the costs of these exemptions, accepting them across society. Extending the same sort of accommodation to those who have religious beliefs that prohibit them from serving in the military, and the consequent cost on third parties, therefore does not violate the Establishment Clause. ${ }^{386}$

\section{The Test in Action}

In explaining the contours of our test, we have already briefly discussed some examples. We now discuss several of those examples in greater detail and consider several others to demonstrate how the test would apply in a variety of cases. For the sake of argument we assume that each of the practices we

381. See id. (showing various "essential employment" deferral categories throughout the history of the Selective Service Act, such as "essential civilian employment" and "essential agricultural employment").

382. See id. (offering exemptions for "hardship" to families, or where "dependents" exist).

383. See Fast Facts About Selective Service, SElective SERV. Sys., https://www.sss.gov/Public-Affairs/Juvenile-Justice-Toolkit/Fast-Facts (last updated Aug. 21, 2014) (last visited Feb. 12, 2016) ("In a crisis requiring a draft, men would be called in sequence determined by random lottery number and year of birth.") (on file with the Washington and Lee Law Review).

384. See U.S. DeP'T OF Def., Instruction No. 1300.06, Conscientious OBJECTORS (2007), http://www.dtic.mil/whs/directives/corres/pdf/130006p.pdf (outlining exemptions for conscientious objectors under the current Selective Service Act).

385. See Yoder, supra note 379 (showing various "available for service" and "limited service" classifications for those who do not meet exemption criteria).

386. Such an accommodation would likely pass muster under a modern Establishment Clause evaluation. See Lemon v. Kurtzman, 403 U.S. 602, 61213 (1971) (discussing the three "main evils" that constitute a violation of the Establishment Clause, including a "secular legislative purpose" and not fostering "government entanglement with religion"). 
introduce has a religious basis. ${ }^{387}$ We also consider how our analysis compares to the decisions of American policymakers and judges. In some cases, the law is aligned with our test; in others, our test would require changes to the law.

\section{Cases Involving Religious Practices that Allegedly Harm In-Group Children}

First, consider cases on opposite sides of the harm spectrum. On the one hand are religious practices that involve withholding medical treatment of children. ${ }^{388}$ State legislatures have treated this practice with astonishing solicitude-"Nearly every state provides exemptions in their child abuse, neglect, or endangerment statutes for spiritual healing"389-while three states go so far as to allow parents to "assert their religious beliefs as an affirmative defense to murder." 390 In other words, although the state typically demands, at pain of criminal sanction, that parents provide appropriate health care and treatment for their children, virtually every state legislature has decided to accept greater risk to the health and life of children of religious parents. ${ }^{391}$

For a specific example of denial of medical care, Jehovah's Witnesses do not accept blood transfusion, and some have attempted to prevent their children from obtaining transfusion. ${ }^{392}$

387. Not all of them necessarily do, in fact, and people may disagree about others. We do not take a practical stand on this question and instead simply assume that each of the practices has a religious basis.

388. See supra note 346 and accompanying text (describing treatment of various religious practices denying children medical treatment or care).

389. Jennifer L. Hartsell, Comment, Mother May I... Live? Parental Refusal of Life-Sustaining Medical Treatment for Children Based on Religious Objections, 66 TENN. L. REV. 499, 509 (1999).

390. Id.

391. See id. at 510 ("Most state exemptions provide either that a parent is not abusive or neglectful 'for the sole reason' that the parent uses spiritual treatment[,] or that a child being treated spiritually is not abused or neglected (for that reason alone."').

392. See Jehovah's Witness (WTS) Opposition to Blood Transfusions, RELIGIOUSTOLERANCE.ORG (Sept. 29, 1996), http://www.religioustolerance.org/ witness13.htm (last updated July 27, 2008) (last visited Jan. 22, 2016) ("The Jehovah's Witnesses urge[] its members to refuse to accept blood transfusions and to not allow them to be given to their children. This is 
Our test would allow-indeed, require, under the Establishment Clause-governments to prohibit parents from denying such care because such denial represents a threat to the life of a child, thus comprising a direct effect, that is actual and likely, thus satisfying the Likelihood prong. ${ }^{393}$ There are no comparable mainstream practices permitted by the law, so the Magnitude prong is satisfied. ${ }^{394}$ Indeed, parents who withhold medically necessary treatment from their children for non-religious reasons can be criminally and civilly sanctioned. ${ }^{395}$ Furthermore, courts can reduce parental rights, at least to the extent of appointing a guardian to make health care decisions on the child's behalf. ${ }^{396}$ Indeed, courts have required transfusions under these circumstances, ${ }^{397}$ but they should go further and strike down as unconstitutional those laws that prevent criminal and civil punishment of parents who successfully refuse to allow their children to be transfused or who withhold other critically necessary medical care.

The practice of piercing the ears of infants and minors is at the other end of the spectrum. ${ }^{398}$ This practice is an essentially innocuous one, apart from a small amount of momentary pain

primarily based upon four passages in the Bible which they interpret as prohibiting the consuming of blood.") (on file with the Washington and Lee Law Review).

393. See supra Part IV.A (discussing the Direct Effect and Likelihood prongs of the test, and their operation).

394. See supra Part IV.A.3 (defining the operation of the Magnitude prong of the test).

395. See Hartsell, supra note 389, at 510 (discussing statutes in West Virginia, Arkansas, and Oregon that limit murder exemptions to cases where the practices meet certain requirements and act according to the beliefs of a "recognized religious denomination").

396. See Health Care Decision-Making Authority: Who Makes The Decision?, ABA CoMmission ON L. \& AGING (2015), http://www.americanbar.org/ content/dam/aba/administrative/law_aging/Who_Makes_the_Decision.authcheck dam.pdf (displaying tables with various statutes and ordinances authorizing courts to appoint guardians and terminate parental rights for health care decision-making).

397. See, e.g., State v. Perricone, 181 A.2d 751, 757 (N.J. 1962) (finding that there was a compelling necessity to protect the child).

398. See infra notes 399-402 and accompanying text (examining the costs and effects of ear piercing and suggesting that ear piercing has little impact on children). 
and a small possibility of minor local infection. ${ }^{399}$ Ritual ear piercing would be permissible under our test, both because it does not meet the criteria of the Bases for Possible Restriction and because, in any event, it fails under the Magnitude prong because minors, including infants, commonly have their ears pierced for esthetic reasons. ${ }^{400}$ Not surprisingly, we have found no evidence of American courts or legislatures attempting to ban parentally approved ear piercing of children. ${ }^{401}$

Now consider how the test would apply in some more contentious cases. ${ }^{402}$ Male infant ritual circumcision has become a controversial issue in some Western countries ${ }^{403}$ and even in certain communities in the United States. ${ }^{404}$ Ritual circumcision of infant boys, practiced by Jews and Muslims, is claimed by some to cause major loss of sexual function. ${ }^{405}$ If this were true, it

399. See Jennifer Felsher, Ear Piercing No Longer a Pain, NEWsWisE (Sept. 22, 2000), http://www.newswise.com/articles/ear-piercing-no-longer-a-pain (last visited Jan. 17, 2015) (discussing advances made in ear-piercing technology that may allow metal-sensitive individuals to have their ears pierced) (on file with the Washington and Lee Law Review).

400. See supra Part IV.B.2 (describing the Bases for Possible Restriction and Magnitude prong of the proposed test).

401. Schools, however, can impose, for the purpose of controlling gang activity, dress codes that preclude wearing of body piercings. See, e.g., Long v. Bd. of Educ., 121 F. Supp. 2d 621, 629 (W.D. Ky. 2000) (reflecting for reference the school dress code prohibiting body piercings in a case considering whether the dress code enforcement was discriminatory). If the gangs were organized as religious organizations that preyed violently on outsiders, the earring ban might be acceptable under the Indirect Effects prong. Of note, piercing the ears of kittens is criminal in Pennsylvania. See Commonwealth v. Crawford, 24 A.3d. 396, 405 (Pa. Super. Ct. 2011) (confirming sentence of appellant who used a 14-gauge needle to pierce the ears and scruff of a three-pound kitten, finding that she acted willfully and maliciously).

402. See infra notes 403-410 and accompanying text (considering infant ritual circumcision, facial tattooing and scarification, and limiting child education in the context of the test).

403. See supra note 57 and accompanying text (noting the opposition of Swedish and Danish medical associations and their efforts to ban the procedure).

404. See, e.g., Jennifer Medina, Efforts to Ban Circumcision Gain Traction in California, N.Y. TIMEs (June 4, 2011), http://www.nytimes.com/2011 /06/05/us/05circumcision.html?_r=0 (last visited Jan. 17, 2016) (reporting that one group obtained over 7,100 signatures to ban circumcision of minors) (on file with the Washington and Lee Law Review).

405. See generally Morten Frisch et al., Male Circumcision and Sexual Function in Men and Women: A Survey-Based, Cross-Sectional Study in 
would likely allow states to ban it under our test. ${ }^{406}$ However, this claim has not been borne out by randomized and large case-control trials. ${ }^{407}$ To the contrary, these have shown no adverse effect. ${ }^{408}$ Further, serious complications from ritual circumcision are extremely rare. ${ }^{409}$ Finally, under the prevailing norms in the United States, the third prong of test would also preclude banning ritual circumcision ${ }^{410}$ because infant circumcision is a legal mainstream practice. ${ }^{411}$ To prohibit only religiously motivated infant circumcision would thus violate the Free Exercise Clause. Consequently, circumcision fails to meet the criteria required for regulation under our test as causing objective harm. ${ }^{412}$ Of course, if credible scientific evidence of serious adverse effects of circumcision emerges and if society then bans all medically elective circumcision practices, and not merely ritual circumcision, the status of circumcision under our test would change as well. ${ }^{413}$

Next, we previously discussed briefly the practice of extensive facial tattooing and scarification. ${ }^{414}$ Consider a religious

Denmark, 40 INT'L J. EPIDEMIOLOGY 1367 (2011) (studying circumcision and its effects on sexual function).

406. See infra notes 407-414 and accompanying text (discussing the impacts of ritual circumcision and analyzing them in reference to the authors' proposed test).

407. See Helen A. Weiss et al., Complications of Circumcision in Male Neonates, Infants and Children: A Systematic Review, 10 BMC URoLogy 3-5 (2010) (surveying twenty-six studies regarding the outcomes of circumcision procedures in infants and young children).

408. See id. at 3 (stating that most of the studies surveyed reported no severe adverse events, indicating no significant loss of sexual function).

409. See id. (noting that three studies of infants found that $1 \%-2 \%$ of boys experienced a serious complication as a result of circumcision).

410. See supra Part IV.A.3 (acknowledging societal tolerance for certain activities under the Magnitude prong of the test).

411. See Sarah E. Waldeck, Using Male Circumcision to Understand Social Norms as Multipliers, 72 U. CIN. L. REV. 455, 457 (2003) (discussing why male circumcision is a social norm).

412. See supra Part IV.A (proposing that the government may restrict a religious practice if it has high likelihood of significant negative effects as long as society does not tolerate harms from a similar practice).

413. See supra Part IV.A.3 (recognizing that if the government restricts a secular practice that is comparable to a religious practice, the analysis for the third prong of the proposed test changes).

414. See supra Part IV.B.2.c (referencing facial tattooing as an example of a 
culture whose members traditionally cover most of their faces with tattoos at the onset of puberty. 415 The tattoo designs are simultaneously both an indicator of status and an expression of religious devotion. ${ }^{416}$ However, a face largely covered with tattoos likely would be a barrier to employment and to social integration in the United States. Arguably, then, the practice would trigger the Direct Effects prong, and the state could try to prevent underage children from having facial tattoos, even over the objection of the parents and children. ${ }^{417}$ Notably, laws already prohibit elective tattooing of minors, ${ }^{418}$ and so a ban on ritual tattooing would be consistent with the Magnitude prong. ${ }^{419}$

A similar analysis might apply to religious groups that limit the education of children to an extent that makes it difficult for them to function economically in society. ${ }^{420}$ In Wisconsin $v$. Yoder, ${ }^{421}$ the Supreme Court allowed Amish parents to terminate their children's education before the age otherwise mandated by the state. ${ }^{422}$ The Court did not support the Amish categorically, however. ${ }^{423}$ Rather, it balanced the interests of the Amish against those of the state. ${ }^{424}$ While it found that the state requirements

practice that may have an adverse social stigma affecting employability).

415. See generally Palmer \& Tano, supra note 340 (describing Maori cultural tradition of facial tattoos, which provided information about the individual).

416. See id. (discussing the moko, which is connected to religious life of the Maori and also showed the status of an individual).

417. See supra Part IV.A.1.a (proposing that a state could regulate religious activities that have a negative direct effect on societal engagement and integration).

418. See, e.g., GA. CodE ANN. § 16-5-71 (2012) ("It shall be unlawful for any person to tattoo the body of any person under the age of $18 \ldots$. .); FLA. STAT. $\S 381.00787$ (2012) ("A person may not tattoo the body of a minor child younger than 16 years of age ....").

419. See supra Part IV.A.3 (proposing that a religious practice may only be restricted where it is not similar to an activity accepted by society).

420. See, e.g., Wisconsin v. Yoder, 406 U.S. 205, 221 (1972) (comparing the state's interest in the importance of education to an individual's ability to engage in and contribute to society with the Amish belief in limited education).

421. 406 U.S. 205 (1972).

422. See id. at 234-35 (holding that "the First and Fourteenth Amendments prevent the State from compelling residents to cause their children to attend formal high school to age 16").

423. See id. at 213-15 (noting the state's interest in educating its citizens).

424. See id. (weighing the state's interest in education against the fundamental Amish interest in directing their children's education). 
would be highly disruptive to the Amish "community and religious practice," 425 it also found that the Amish were "successful and self-sufficient," 426 and that the education they gave their children did "not impair the physical or mental health of the child, or result in an inability to be self-supporting or to discharge the duties and responsibilities of citizenship, or in any other way materially detract from the welfare of society." 427 Today, this analysis is open to renewed question, as the decision not to formally educate children past the eighth grade may prevent those who wish to leave Amish society from successfully integrating into broader society. ${ }^{428}$

Importantly, some lower courts have rejected parallel educational accommodations for other religious groups that did not have a similar track record of successfully preparing their children to function economically. ${ }^{429}$ Even if the Amish continue to enjoy the protections of Yoder, legislatures and courts must carefully consider whether other religious individuals and groups who refuse to meet state-imposed educational requirements impose direct costs on the children or indirect costs on society (by making society responsible for their economic maintenance as adults) by limiting their education. Thus, private religious schools that refuse to teach children English or foundational skills should be subjected to intense legal scrutiny and, perhaps, outlawed. ${ }^{430}$

425. Id. at 218 .

426. Id. at 235 .

427. Id. at 234 .

428. See Gage Raley, Yoder Revisited: Why the Landmark Amish Schooling Case Could—and Should-Be Overturned, 97 VA. L. REv. 681, 694-95 (2011) (arguing that Amish children are not prepared to be economically productive if they leave the Amish community because the skillset necessary for successful engagement in modern society has changed since the Supreme Court's decision in Yoder).

429. See, e.g., Duro v. Dist. Attorney, Second Judicial Dist., 712 F.2d 96, 99 (4th Cir. 1983) (holding that North Carolina's interest in compulsory education outweighed the Pentecostalists' religious interest); Blackwelder v. Safnauer, 689 F. Supp. 106, 148 (N.D.N.Y. 1988) (finding that New York's minimum standards of instruction for school-aged children were valid).

430. See, e.g., Jennifer Miller, Yiddish Isn't Enough, N.Y. Times (Nov. 21, 2014), http://www.nytimes.com/2014/11/23/nyregion/a-yeshiva-graduate-fightsfor-secular-studies-in-hasidic-education.html?_r=0 (last visited Jan. 18, 2016) (describing the limited education provided by Jewish private schools in New 
We do not mean to suggest that homeschooling and other means of privately educating children for religious reasons should be prohibited because of assumed direct harm to children. ${ }^{431}$ Indeed, studies show that homeschooled children are typically well-prepared for higher education or to obtain jobs as adults. ${ }^{432}$ However, we do think that states have an obligation to monitor and regulate alternative educational arrangements to ensure that children receive basic education in critical subjects to allow them to seek a range of employment opportunities as adults. This could include mandatory testing in some subjects or basic curricular requirements. ${ }^{433}$ Note, though, that if states allow people to homeschool for both religious and non-religious reasons, the Magnitude prong of our proposed test would only require that all groups are subjected to the same requirements for setting standards for educational progress and for monitoring those standards. ${ }^{434}$

York) (on file with the Washington and Lee Law Review); Frimet Goldberger, When Hasidic Boys Grow up Without Real School, ForWARD (Mar. 11, 2014), http://forward.com/sisterhood/194267/when-hasidic-boys-grow-up-without-realschool/ (last visited Jan. 18, 2016) (discussing the effects of Hasidic schools in Canada, where students learn only rudimentary English) (on file with the Washington and Lee Law Review).

431. See Nicole Stelle Garnett \& Richard W. Garnett, School Choice, the First Amendment, and Social Justice, 4 TEx. REV. L. \& PoL. 301, 313-14 (2000) (discussing when the state should intervene in parents' educational decisions).

432. See Lynn O'Shaughnessy, Can Homeschoolers Do Well in College?, CBS NEws (July 20, 2010, 7:09 PM), http://www.cbsnews.com/news/canhomeschoolers-do-well-in-college/ (last updated July 22, 2010) (last visited Jan. 18, 2016) (discussing new research showing the success of homeschooling) (on file with the Washington and Lee Law Review).

433. States currently impose a range of different requirements on homeschoolers, from virtually none at all to extensive testing. See McMullen, supra note 8 , at 87 (describing the three categories of homeschooling laws in effect in various states). It is beyond the scope of this Article to consider all possible approaches, but we believe that states that impose no requirements are derelict in their obligations. On the other hand, some states may impose too many requirements if they require educational achievement beyond that which would be sufficient to prepare adequately children for a range of careers, or if they require testing beyond that which is required in public schools.

434. See supra Part IV.A.3 (proposing a test prong that compares religious practices with mainstream acceptance of a practice with a similar magnitude of harm). 


\section{Cases Involving Potential Harm to Third Parties}

Now consider mandatory childhood vaccination laws. Every state requires children to be vaccinated against deadly diseases to attend school. ${ }^{435}$ When the federal government enacted the Child Abuse Prevention and Treatment Act of $1974^{436}$ and adopted related regulations, it conditioned federal funding for states upon their inclusion of religious exceptions to mandatory vaccination laws. ${ }^{437}$ Although the Act's religious exception mandate was later repealed, 438 the vast majority of states had by then adopted such exceptions. ${ }^{439}$ Fully forty-seven states now accommodate religious and other conscientious objectors by allowing them to opt out of childhood vaccination schedules. ${ }^{440}$ These carve-outs for religious objections to vaccination laws aptly illustrate the interest group dynamic that sometimes privileges and protects even disfavored religious practices. ${ }^{441}$ The majority of people support mandatory vaccination laws and oppose such exemptions. ${ }^{442}$ Yet those who

435. See, e.g., OR. REV. STAT. § 433.267 (2015) (requiring that children shall provide records of their vaccinations "[a]s a condition of attendance in any school or childrens facility" in the state).

436. 42 U.S.C. $\S \S 5101-5119 c$ (2012).

437. See Ross D. Silverman, No More Kidding Around: Restructuring Non-Medical Childhood Immunization Exemptions to Ensure Public Health Protection, 12 AnNALs HEALTh L. 277, 282 (2003) (noting the effect of the federal act on the enactment of "state laws offering medical exemptions based on religious grounds occurred”).

438. Id.

439. Id. Only seventeen states appear to extend these exemptions to non-religious objectors. Id. at 284 . Note that California has recently become the third state to eliminate all exemptions, except where there are medical reasons that a child cannot be vaccinated. See Michael Martinez \& Amanda Watts, California Governor signs vaccine bill that bans personal, religious exemptions, CNN (June 30, 2015), http://www.cnn.com/2015/06/30/health/california-vaccinebill/ (last visited Jan. 18, 2016) (discussing California's Senate Bill 277) (on file with the Washington and Lee Law Review).

440. Silverman, supra note 437, at 282.

441. See supra Part III.B (outlining the relationship between public accommodations and interest group advocacy and suggesting that religious groups function as interest groups).

442. See Alistair Bell, Big U.S. Majority Favors Mandatory Vaccinations, HufFington Post (Feb. 24, 2015, 7:00 AM), http://www.huffington post.com/2015/02/24/poll-big-us-majority-fa_n_6742162.html (last updated Apr. 26,2015 ) (last visited Jan. 18, 2016) (stating that $78 \%$ of the people surveyed said children should be vaccinated unless they have a health risk) (on file with 
support the exemptions are passionate and active proponents of practices they consider vital, whereas opponents are dispersed and disorganized because the issue is of low priority for them. ${ }^{443}$ Consequently, politicians have been responsive to the minority. ${ }^{444}$

The practice of withholding vaccinations against serious illnesses could be analyzed under the Direct Effects basis because it carries risks for the unvaccinated children of the religious group. ${ }^{445}$ However, it also falls under the Indirect Effects basis because it also imposes risks on outsiders. ${ }^{446}$ Children who cannot be vaccinated because of compromised immune systems or due to allergies to ingredients in vaccines, and others for whom vaccination fails, rely on high vaccination rates. ${ }^{447}$ Indeed, there have been recent deadly outbreaks of preventable diseases, and outsiders as well as the children of those engaged in the religious practice have suffered as a result. ${ }^{448}$ Under our test, states mayindeed, perhaps must-eliminate such exemptions. ${ }^{449}$ The risks of non-vaccination are likely in certain communities and grave for both children within the group and the vulnerable outside the

the Washington and Lee Law Review).

443. See supra notes 191-193 and accompanying text (discussing how a minority advocate for a measure may be more successful when there is a weak majority opposition).

444. See Silverman, supra note 437, at 282 (noting the almost universal adoption of state law religious exemptions from school immunization requirements). This dynamic is not preordained, however. In the wake of deadly outbreaks of preventable childhood diseases, the broader public sometimes becomes focused on the issue sufficiently to provoke changes in the law to limit or eliminate such exemptions. This recently occurred in California. See Martinez \& Watts, supra note 439 (providing coverage for California's passage of a bill removing all exemptions for vaccinations except where children have a health reason).

445. See supra Part IV.A.1.a (proposing that a practice should be regulated if it subjects vulnerable populations, such as children, to severe risk of harm or death).

446. See supra Part IV.A.1.b (proposing that a practice should be regulated if it places a severe burden on society).

447. See Silverman, supra note 437, at 278-79 (discussing the benefits of mandatory childhood vaccinations).

448. See Sifferlin, supra note 157 (describing the recent cases of measles in New York City); Doucleff, supra note 157 (discussing the outbreaks of whooping cough).

449. See supra Part IV.A (proposing that religious practices may be regulated when their direct or indirect effects are severe as long as there is no comparable secular practice accepted by society). 
group (satisfying the Likelihood prong). ${ }^{450}$ Many states also provide for directly observed therapy for tuberculosis medications or quarantine for health professionals exposed to Ebola (satisfying the Magnitude prong). ${ }^{451}$ Consequently, legislatures should act to change their vaccination laws. Failing that, courts should perhaps strike down vaccine exemptions under the Establishment Clause.

The test also applies to the question of whether and how to accommodate medical practitioners whose religious beliefs prohibit them from providing certain medical services. ${ }^{452}$ In some cases, allowing these medical practitioners to decline to provide certain medical services can harm individuals seeking those services. $^{453}$ Several federal statutes allow health care professionals and institutions with religious objections to refuse to provide care related to abortion and sterilization procedures. ${ }^{454}$

450. See Silverman, supra note 437, at 278-79 (outlining the significant societal benefits of vaccines). We think that parallel exemptions for conscientious objectors are reasonably considered religious in nature, but we recognize that some may disagree and argue that these are better understood as comparable mainstream practices. If so, then a state that offers such exemptions must also offer religious vaccination exemptions, but a state may not offer only religious exemptions. In any event, we believe that the risks associated with non-vaccination are so severe for certain childhood diseases that only well-documented medical exceptions should be granted.

451. See generally Jeffrey M. Drazen et al., Ebola and Quarantine, $371 \mathrm{NEW}$ Eng. J. MED. 2029 (2014); Self-Study Modules on Tuberculosis, CTRS. FOR Disease CONTROL \& PREVEnTION, http://www.cdc.gov/tb/education/ ssmodules/module9/ss9reading2.htm (last updated Sept. 1, 2012) (last visited Jan. 18, 2016) (on file with the Washington and Lee Law Review).

452. See infra notes 453-464 and accompanying text (discussing the application of the proposed test in the context of contraception).

453. See, e.g., Erin Daly, Reconsidering Abortion Law: Liberty, Equality, and the New Rhetoric of Planned Parenthood v. Casey, 45 AM. U. L. REv. 77, 78 (1995) ("Despite forceful and increasingly frequent arguments that the harm caused by restrictive abortion laws deny equal protection, at least as much as they impinge on personal privacy, the Court has steadfastly refused to consider abortion in this light.").

454. See 42 U.S.C. $§ 238 n$ (2012) (prohibiting discrimination by government licensing entities of an entity that refuses to participate in or offer trainings in the performance of induced abortions); id. $\S 300 a-7$ (addressing the exceptions for sterilization and abortion); 45 C.F.R. $§ 88.1$ (2015) (stating that the purpose of the section is "to provide for the enforcement" of several acts "referred to collectively as the 'federal health care provider conscience protection statutes"'); Maxine M. Harrington, The Ever-Expanding Health Care Conscience Clause: The Quest for Immunity in the Struggle Between Professional Duties and Moral 
States have overwhelmingly followed the lead of the federal government and in some respects have gone much further. ${ }^{455}$ According to the Guttmacher Institute, forty-five states allow individual health care providers to refuse to provide abortion services normally provided by identical professionals. ${ }^{456}$ Of these, forty-three allow even government-owned health care institutions to refuse to provide such services, while thirteen give the dispensation only to private institutions. ${ }^{457}$ Moreover, eighteen states allow providers to refuse to provide sterilization services; ten allow providers to refuse to provide services related to contraception; between six and twelve permit pharmacists to refuse to dispense contraceptives; and nine allow health care institutions to refuse to provide contraceptive services. ${ }^{458}$ This does not tell the whole story, as participation is not necessarily explicitly required in other states, and we are unaware of situations in which government has sanctioned health care professionals for refusing to provide services in the area of reproductive control.

Under the proposed test, whether such accommodations are advisable, or even permissible, is highly fact-dependent. ${ }^{459}$ The nature of the service being sought matters a great deal, as does the relative ease with which the person seeking the service may obtain them elsewhere. ${ }^{460}$ Both factors go to the nature of the burdens that the religious practitioner imposes on others. ${ }^{461}$ If a proposed law allows a pharmacist to decline to fill a prescription for contraception, but only where another employee in the

Beliefs, 34 FLA. ST. U. L. REV. 779, 781 (2007) (discussing the trend of legislation that allows physicians to refuse treatment options).

455. Guttmacher Inst., State Policies in Brief: Refusing to Provide HEALTH SERVICES (2016).

456. Id.

457. Id.

458. Id.

459. See supra Part IV.A (outlining the proposed test as an analysis of various factors which are heavily reliant on the specific context of the religious practice in question).

460. See supra Part IV.A (proposing the test's prongs that consider the direct effects of the religious practice on individuals and the burden or likelihood of those effects).

461. See supra Part IV.A.2 (describing the Likelihood prong of the proposed test). 
pharmacy is available and willing to do so, then the medical and economic costs are almost altogether mitigated and the religious practice must be tolerated. ${ }^{462}$ If, on the other hand, a proposed law provides an absolute right for every pharmacist to decline to fill the prescription and there is no other pharmacy in close proximity, then the harms and costs may be substantial enough to prohibit the religious practice. ${ }^{463}$ A proposed law that allows a pharmacist to decline to provide the medication, but only if she will transfer the prescription to a vendor within a radius of five miles who is available and willing to fill it, presents a middle case. ${ }^{464}$ We encourage policymakers and judges to apply our test in this fact-specific manner using accepted medical criteria for harm (such as considering unwanted pregnancy to be a harm) to resolve such questions.

\section{The Test's Implications and Limitations}

Our test for resolving these conflicts has potential implications for a wide range of clashes between law and religion, but it also has some important limitations. ${ }^{465}$ We identify and address these in this Part.

A. The Test Primarily Applies Only to a Limited Category of Cases, but It May Have Important Implications for Many Others

As currently conceived, the test is intended to apply primarily to cases in which the risks and harms associated with a

462. See, e.g., 49 PA. CODE $§ 27.103$ (2015) (declaring that a pharmacy should reasonably accommodate the pharmacist's beliefs while assuring the delivery of services that the patients need).

463. On the other hand, compelling professionals to perform acts that they conscientiously object to might cause them to leave localities where such professionals are scarce, further compounding problems of access to care. It may also dissuade people from entering those specialties. Even if a government action is permissible under our test, it is not necessarily wise.

464. See, e.g., 49 PA. CODE $§ 27.103$ (creating obligations for pharmacists who refuse to fill prescriptions based on religious beliefs).

465. See infra Parts V.A-C (discussing the application of the proposed text to a limited category of cases, its constraints on prohibiting religious practices altogether, and its inability to resolve certain cases). 
religious practice are primarily health or medically related, though economic and education-related applications also may come into play. ${ }^{466}$ In contrast to other kinds of harms, these harms are relatively concrete and often quantifiable, and therefore reasonably susceptible to the kind of balancing and comparisons the test demands. ${ }^{467}$ The test does not necessarily apply in the same way to a variety of other kinds of cases involving conflicts of rights in which such quantifiable risks and harms are not implicated. ${ }^{468}$

For instance, one of the highest profile and most politically charged contemporary law and religion debates concerns whether there should be religious accommodations for laws that prohibit discrimination on the basis of sexual orientation. ${ }^{469}$ Such accommodations plainly impose costs and harms on third parties, and anti-discrimination laws typically do not include comparable exceptions for mainstream practices. ${ }^{470}$ However, the primary harms in such cases are not usually of the sort contemplated by the test; rather, they are dignitary harms. ${ }^{471}$ We do not mean to suggest that such harms are not "real." Indeed, dignitary harms of the sort imposed by a real or proverbial "no gays allowed" sign on a business are in some senses among the most painful. ${ }^{472}$ But

466. See supra Part IV.C (examining the application of the proposed test in the contexts of ear piercing, facial tattooing, circumcision, contraception, and education).

467. See supra Parts IV.A-C (outlining the prongs of the proposed test, the analysis associated with each prong, and the application of the test to several more concrete religious practices, such as ear piercing and circumcision).

468. See infra notes 469-473 and accompanying text (introducing and discussing religious accommodations for sexual orientation discrimination as an example of a category of cases that the test is not equipped to address).

469. See generally George W. Dent, Jr., Civil Rights for Whom? Gay Rights Versus Religious Freedom, 95 KY. L.J. 553 (2007) (discussing the debate about whether religious groups can discriminate based on sexual orientation).

470. See Andrew Koppelman, You Can't Hurry Love: Why Antidiscrimination Protections for Gay People Should Have Religious Exemptions, 72 BRoOK. L. REV. 125, 131-37 (2006) (discussing the effects of religious exemptions from antidiscrimination protection of gay people).

471. See Douglas Nejaime, Marriage Inequality: Same-Sex Relationships, Religious Exemptions, and the Production of Sexual Orientation Discrimination, 100 CALIF. L. REV. 1169, 1228 (2012) (discussing the extent of the harm to one's dignity that results from discrimination).

472. See Melissa Chan, Tennessee Hardware Store Owner Posts 'No Gays Allowed' Sign on Front Door: 'I'll Never Regret This,' N.Y. DAILY NEWs (July 1, 
they are not quantifiable. ${ }^{473}$ Thus, while we do not discount the possibility that the test could play a guiding role in deciding such cases, the matter requires further consideration.

Of course, in some cases the harms of such religious accommodations are indeed economic, such as in geographic areas where gay and lesbian individuals may not easily be able to obtain services from alternative, non-objecting service providers. ${ }^{474}$ In such cases, the test should certainly guide the decision whether and how to accommodate religious objectors. ${ }^{475}$ For an example of how policies could be crafted in such cases, some states provide that pharmacists with religious objections to dispensing certain medications may decline to do so, but only if someone else in the same pharmacy is prepared to do so. ${ }^{476}$ Similarly, in the same-sex marriage context, Utah recently enacted an intriguing compromise that exempts government officials with religious objections to same-sex marriage from providing marriage licenses but provides that someone must be available who is willing to do so. ${ }^{477}$ These kinds of compromises are reasonable attempts to balance the values of pluralism and religious freedom against those of monism and the protection of the interests of third parties in a manner compatible with the mandates of the religion clauses. ${ }^{478}$

2015), http://www.nydailynews.com/news/national/tennessee-hardware-storeowner-posts-no-gays-allowed-sign-article-1.2277673 (last visited Jan. 18, 2016) (discussing a business owner that put a "No Gays Allowed" sign on the front door) (on file with the Washington and Lee Law Review).

473. See Nejaime, supra note 471, at 1228 (considering the distinction between a status-based harm and insulted dignity as examples of outcomes from discriminatory behavior).

474. See, e.g., infra notes 476-477 and accompanying text (discussing Pennsylvania and Utah as examples of states where it may be more difficult to get access to contraceptives or marriage licenses).

475. See supra Parts IV.A-B (providing a framework for applying the proposed test where the religious practice is concrete and leads to concrete harms).

476. See, e.g., 49 PA. CODE $§ 27.103$ (2015) (creating obligations for pharmacists who refuse to fill prescriptions based on religious beliefs).

477. See UTAH Code ANN. §63G-20-201 (LexisNexis 2015) (prohibiting a state official from requiring a religious official to solemnize a marriage contrary to the religious official's beliefs); id. $§ 17-20-4$ (enumerating the duties of a county clerk).

478. See supra Part III (exploring the considerations involved in determining whether or not to accommodate religiously motivated exceptions to 


\section{B. The Test Does Not Always Mandate the Prohibition of Religious Practices, Even Where Its Conditions Are Met}

One implication of the test is that at least some religious practices that meet the criteria of the first prong should not be tolerated by society, so long as the limitations in the Likelihood and Magnitude prongs are not implicated. ${ }^{479}$ This comports both with a just society's interest in and obligation to protect citizens from harms imposed by others and with the Establishment Clause concern of giving special legal license for religious groups to harm others. ${ }^{480}$ However, we do not mean to imply that society must necessarily ban all such practices. There are at least two circumstances in which legal prohibition is not necessarily warranted and where, ultimately, policymakers' judgments ought to be respected. ${ }^{481}$

First, reasonable people may disagree as to what kinds of harms meet the criteria under the Bases for Possible Restriction to make prohibition of the associated religious practice appropriate. ${ }^{482}$ In using terms like "unreasonable burdens," "sufficiently deleterious effects," "substantial chance," and "objectively severe" in the first prong, we recognize that these terms necessitate judgment. 483 Some policymakers and societies may tolerate more externalization of risks and costs than others, and therefore may come to different conclusions as to whether the potential harms associated with a given religious practice are intolerable for that society. To be clear, if the society prohibits comparable mainstream practices, then the Establishment

laws).

479. See supra Part IV (describing the proposed test and providing examples of religious practices that satisfy its parameters).

480. See supra Part III (discussing the development of accommodations through political advocacy for certain activities recognized by society as harmful).

481. See infra notes 482-489 and accompanying text (noting circumstances where there is disagreement about the extent of the harms resulting from a practice or where banning a practice may actually create more significant problems).

482. See supra Parts IV.A-B (discussing the considerations for applying the Bases for Possible Restriction to various religious practices).

483. Supra Part IV.A.1. 
Clause may require it to prohibit the religious practice as well. ${ }^{484}$ However, where there is no comparable mainstream practice, it might better be left to policymakers rather than courts-except perhaps in the most extreme cases-to decide whether the religious practice is tolerable. ${ }^{485}$

Second, even where a religious practice is clearly intolerable under the test, it is not necessarily the case that the best or necessary course is for society to prohibit the practice as a legal matter. ${ }^{486}$ Sometimes banning a practice can be counterproductive and ineffective in achieving the desired result, whereas an alternative approach-such as through educational initiatives, attempts to persuade, or other "nudges"-may be more productive. ${ }^{487}$ This is true, of course, for non-religious practices as well; most American jurisdictions do not ban alcohol use despite the potential deleterious effects of drinking. ${ }^{488}$ Again, these are typically decisions to be left to policymakers. ${ }^{489}$

\section{The Test Does Not Resolve All Cases in Which It Applies}

Perhaps the most important limitation of the test is that, even where it is implicated, that is, where religious practices potentially impose health or economic harms, it will not provide a clear resolution to every church-state conflict. ${ }^{490}$ In the most basic

484. See supra Parts III.A-B (providing background for situations when religious practices do not receive accommodations).

485. See infra Part V.C (discussing the role of policymakers in circumstances when the proposed test does not achieve the desired result).

486. See infra notes 487-489 and accompanying text (considering the potential negative effects of banning or regulating a particular practice).

487. See, e.g., Steve P. Calandrillo, Vanishing Vaccinations: Why Are So Many Americans Opting Out of Vaccinating Their Children?, 37 U. MICH. J.L. REFORM 353, 437 (2004) (explaining how punishing vaccination resistors was ineffective and why it is necessary to educate parents regarding the risks of diseases compared to vaccines).

488. See Data and Maps, Ctrs. For Disease Control \& Prevention, http://www.cdc.gov/alcohol/data-stats.htm (last updated Nov. 16, 2015) (last visited Jan. 20, 2016) (reflecting state-by-state binge drinking and listing some of the dangers associated with excessive drinking) (on file with the Washington and Lee Law Review).

489. See infra Part V.C (discussing the role of policymakers in the context of the separation of church and state).

490. See infra notes 491-494 and accompanying text (discussing the 
sense, the test cannot resolve all cases for the same reason that other legal tests cannot: reasonable people will reasonably disagree. With respect to our test, reasonable people may reasonably disagree about the magnitude of the risks associated with a particular religious practice. ${ }^{491}$ Some policymakers will consider certain costs tolerable, while others will find the same costs intolerable. ${ }^{492}$ Consequently, they may disagree as to how to treat the religious practice under the first prong of the test. ${ }^{493} \mathrm{As}$ already noted, terms in the first prong like "unreasonable burdens," "sufficiently deleterious effects," "substantial chance," and "objectively severe" require the application of judgment, and people's judgment may differ in different cases. ${ }^{494}$ But this lack of certitude is not something that should concern us any more than it does in the case of any other legal test. In many cases, the correct result is clear, which is a sufficient benefit in itself. ${ }^{495}$ And in those cases where the correct result is reasonably subject to dispute, the test still represents an improvement over the current ad hoc and unprincipled approach if it succeeds in orienting policy debates towards a principled discussion concerning the nature, magnitude, and tolerability of the costs imposed by the religious practice in question.

The Magnitude prong of the test presents a different set of difficulties. ${ }^{496}$ This prong asks policymakers, and especially

challenges presented by the uncertain nature of the proposed test's interpretation by different decision-makers in different contexts).

491. See infra notes 492-494 and accompanying text (addressing the qualitative nature of the assessment in the first prong of the proposed test and its susceptibility to varying applications).

492. See, e.g., supra Part IV.C (providing examples of religious practices that have yielded contrasting responses from policymakers, such as childhood education).

493. See supra Part III.A (outlining the parameters of the direct and indirect effect analysis under the first prong of the test, which requires decision-makers to assess the harms associated with a particular religious practice).

494. See supra Part IV.A.1 (providing a discussion of the proposed test's specific factors).

495. See supra Part IV.C (applying the proposed test to several religious practices, such as circumcision and facial tattooing, and finding that the test achieves a correct result in these concrete cases).

496. See infra notes 497-499 and accompanying text (noting that the third prong of the proposed test is not relevant where a unique religious practice does not have a mainstream counterpart). 
judges, to examine challenged religious practices in the context of comparable mainstream practices and to treat them similarly. ${ }^{497}$ But not every religious practice has a comparable mainstream practice. ${ }^{498}$ Some practices may be unique to certain religious groups and not replicated by others.499 Consider some ultra-Orthodox ${ }^{500}$ Jews's practice of metzitzah b'peh ${ }^{501}$ during the infant circumcision ritual, in which the mohel briefly applies direct oral suction to the circumcision wound. ${ }^{502}$ In rare cases, where the mohel carries the herpes simplex virus, this practice can transmit the virus to the child, which can be fatal. ${ }^{503}$ In considering whether to tolerate or prohibit this religious practice - or to undertake other means to reduce its prevalence

497. See supra Part IV.A.3 (proposing that a religious practice not be restricted if a comparative and commonly practiced secular activity exists).

498. See, e.g., James Pellerin \& Michael B. Edmond, Infections Associated with Religious Rituals, 17 INT'L J. INFECTIOUs DisEASE e945, e945 (2013) (exploring the potential infections resulting from the Hindu side roll, where devotees lay on their sides and roll along the same path as the icons of various deities, contracting skin infections as a result of canine fecal material along the same path).

499. See infra notes 500-503 and accompanying text (introducing and discussing the distinctive religious practice metzitzah b'peh).

500. We use the term "ultra-Orthodox" as a term that many of our readers will recognize as a descriptor of those Jews whose especially extensive rules of conduct creates physical and psychological separation not only from non-Jews, but from Jews whose observance is more lenient. Those to whom the term is applied do not use it themselves, and this term may be unfair both to them and to Orthodox Jews. Rather, they call themselves Charedim (singular, Charedi), a term we eschew because many readers would not recognize it. See Jodi Rudoren, Israel Prods Ultra-Orthodox to 'Share Burden,' N.Y. Times (June 6, 2013), http://www.nytimes.com/2013/06/07/world/middleeast/israels-ultra-orthodox-

fight-to-fit-in.html (last visited Jan. 20, 2016) (describing ultra-Orthodox Jews in Israel using the term "Haredim," reflecting the variable spellings of Hebrew terms translated to English) (on file with the Washington and Lee Law Review).

501. See Pellerin \& Edmond, supra note 498, at e946-e947 (reviewing the existing medical literature for specific religious practices associated with infection, such as metzitzah b'peh and the shared chalice of Christian communion). An alternative spelling is "metzitzah be'peh"; the term means "suction by mouth" in Hebrew. See Jamie Cole Kerlee, Too Much Religious Freedom? Infants Infected with Herpes After Jewish Mohel Applies Oral Suction to Circumcised Penises, 19 J.L. \& Health 297, 300 (2005) (using the spelling "metzitzah be'peh" to refer the practice).

502. Pellerin \& Edmond, supra note 498, at e945-e946.

503. See id. (noting the documented cases linking outbreaks of herpes in male infants shortly after undergoing the metzitzah ritual). 
and the risks it imposes - the Magnitude prong of the test invites policymakers to consider how the law treats analogous mainstream conduct. ${ }^{504}$ Yet we are unaware of any comparable non-religious practice of placing one's mouth in brief contact with a child's penis. ${ }^{505}$ The law simply has no provision for such a practice-except, of course, where the contact is sexual in nature, which is not an analogous practice ${ }^{506}$-because the practice is unknown to the law outside of this minority religious practice. ${ }^{507}$ In such cases, how should policymakers and judges apply the test?

There are at least three different possible approaches to this sort of problem. 508 The first is to look for the closest mainstream practices to compare the religious practice to. ${ }^{509}$ For example, in addressing the practice of metzitzah b'peh, a policymaker or judge could consider how the law treats other practices that may lead to the transmission of the herpes virus to infants. ${ }^{510}$ Research shows that breastfeeding an infant is a far greater cause of herpes than is metzitzah b'peh, ${ }^{511}$ but the law does nothing to dissuade, let

504. See supra Part IV.A.3 (suggesting that, under the third prong of the proposed test, where a religious practice has a comparable mainstream practice, policymakers should not restrict the religious practice).

505. This is not analogous to sexual crimes because the statutes in those cases require that the intent of the act must be sexual.

506. If it were analogous, the sexual abuse laws would not explicitly require sexual intent.

507. See supra notes 505-506 and accompanying text (discussing the absence of any comparable secular practice or any law regulating this specific religious practice).

508. See infra notes 509-528 and accompanying text (suggesting that policymakers look to the closest practice and that courts apply strict scrutiny, or that decision-makers apply the test according to their roles, the case, and the most relevant test prongs).

509. See infra notes 510-512 and accompanying text (introducing a comparison between metzitzah b'peh and breastfeeding and considering the two against the proposed test).

510. See infra note 512 and accompanying text (demonstrating that government is supportive of breastfeeding without distinguishing mothers who may have the herpes simplex virus).

511. See, e.g., Mary Boyd, Herpes: From Mom to Baby—and Back Again, Via Breastfeeding, CONSUlTANT FOR PEDIATRICIANS (2009), http://www.pediatrics consultant360.com/content/herpes-mom-baby\%E2\%80\%94and-back-again-breast -feeding (last visited Jan. 22, 2016) (noting that reported incidents of herpes transmission due to breastfeeding are extremely rare) (on file with the Washington and Lee Law Review). 
alone prohibit, carriers of the virus from breastfeeding their children. ${ }^{512}$ From this, some may conclude that the law is apparently indifferent to or tolerant of practices that impose far greater risks of herpes transmission, and consequently, that it must also tolerate metzitzah b'peh.

We are highly skeptical of this approach, because the comparison between the two practices (breastfeeding and metzitzah b'peh) is inapt. Breastfeeding, unlike the metzitzah b'peh practice, potentially carries with it substantial quantifiable health and economic benefits that may outweigh the similarly quantifiable health risks. ${ }^{513}$ Further, even if it were in theory sensible to regulate breastfeeding, it would be impossible to do so given the nature of the mother-child relationship in which breastfeeding takes place. ${ }^{514}$ It is simply impractical for the law to require mothers to be tested for herpes before being "licensed" to breastfeed their children. ${ }^{515}$ In contrast, because mohels are trained professionals who offer their services for payment, the law could require them to be regularly tested for the herpes disease or require informed consent of the nature of the risk on the part of the parents before the circumcision takes place. ${ }^{516} \mathrm{In}$ short, where there is no directly analogous mainstream practice to the religious practice, we caution against using only marginally similar mainstream practices as a primary reference

512. See, e.g., A Look at Enacting Breastfeeding Legislation, LA LECHE LEAGUE INT'L, http://www.llli.org/law/lawenact.html (last visited Jan. 22, 2016) (reviewing existing government promotion and regulation breastfeeding) (on file with the Washington and Lee Law Review).

513. See Olha Lutsiv et al., Women's Intentions to Breastfeed: A Population-Based Cohort Study, 120 InT'L J. OBstetrics \& GYNeCOLOGY 1490, 1490 (2013) (describing the benefits of breastfeeding).

514. Cf. Monique Anikwue, Breast Still Best: An Argument in Favor of One HIV Positive Mother's Right to Breastfeed, 9 WM. \& MARY J. WOMEN \& L. 479, 480 (2003) (pointing out the close bonds formed between mothers and their breastfeeding infants and raising the issue of the criminalization of breastfeeding for HIV positive mothers).

515. See Genital Herpes-CDC Fact Sheet, CTRs. For Disease ConTrol \& PREVENTION, http://www.cdc.gov/std/herpes/stdfact-herpes.htm (last visited Jan. 20, 2016) (providing facts about herpes, which is caused by the viruses herpes simplex type 1 and type 2) (on file with the Washington and Lee Law Review). "About one out of every six people aged 14 to 49 years have genital herpes." Id.

516. See generally Kerlee, supra note 501 (explaining the ritual of metzitzah b'peh, including discussions about requiring HSV testing and parental consent). 
point. There are likely to be so many confounding variables that the comparison would be one of apples-to-computers rather than apples-to-apples and tend to confuse more than it illuminates. ${ }^{517}$

A second possibility is to adopt the approach of the Second Circuit and to apply strict scrutiny to any regulation that targets unique religious practices that have no mainstream analog. ${ }^{518}$ That is, any regulation that targets only religious practices-even where the targeting is due to the sui generis nature of the practice-must have a compelling justification, be narrowly tailored to achieve the desired end, and be no more restrictive than necessary. ${ }^{519}$ We believe that this is certainly the correct approach for non-judicial policymakers to adopt, and that this is reflected in how the Bases for Possible Restriction prong and Likelihood prongs of the test work together. ${ }^{520}$ That is, any practice that meets the exacting requirements of these two prongs and thus justifies restriction is almost certain to also pass strict scrutiny. ${ }^{521}$ Consequently, where the Magnitude prong cannot be considered due to the simple absence of any comparable mainstream practices, decision makers have no choice but to consider the Bases for Possible Restriction prong and Likelihood

517. See, e.g., supra notes 513-516 and accompanying text (comparing metzitzah b'peh with breastfeeding and drawing distinctions in terms of regulation).

518. Cent. Rabbinical Cong. of the U.S. v. N.Y.C. Dep't of Health \& Mental Hygiene, 763 F.3d 183, 186 (2d Cir. 2014) (considering whether a requirement to obtain written consent before performing metzitzah b'peh violates the First Amendment and concluding that the regulation must satisfy strict scrutiny because it was neither neutral nor generally applicable).

519. Id.; see also Church of the Lukumi Babalu Aye, Inc. v. City of Hialeah, 508 U.S. 520, 533 (1993) ("Although a law targeting religious beliefs as such is never permissible, if the object of a law is to infringe upon or restrict practices because of their religious motivation, the law is not neutral and it is invalid unless it is justified by a compelling interest and is narrowly tailored to advance that interest." (citations omitted)); Thomas v. Review Bd. of Ind. Emp't Sec. Div., 450 U.S. 707, 718 (1981) ("The state may justify an inroad on religious liberty by showing that it is the least restrictive means of achieving some compelling state interest.").

520. See supra Part IV.B (describing the relationship between the effects of a religious practice and the likelihood of those effects).

521. See supra Part IV.A.1 (using terms like "unreasonable burdens," "sufficiently deleterious effects," "substantial chance," and "objectively severe" to establish the high standard of the Bases for Possible Restriction and Likelihood prongs). 
prongs in isolation. ${ }^{522}$ This probably corresponds to a legislative version of strict scrutiny.

For institutional reasons, however, we are uncertain whether this is the proper approach for courts to adopt. The Magnitude prong naturally lends itself to judicial inquiry because it plays to the institutional strengths of the judiciary-analogizing between cases to ensure equal treatment; 523 whereas the Bases for Possible Restriction and the Likelihood prong, which require decision makers to make fact-based policy determinations and analyses of risk, is more appropriate for legislators and administrative officials. ${ }^{524}$ Simply put, judges may not be equipped to engage in such factual inquiries. ${ }^{525}$ Perhaps, then, judges should defer to legislative and administrative judgments in such cases, absent actual evidence of animus (if the practice is prohibited by statute or regulation), ${ }^{526}$ compelling evidence that the practice imposes unusually large costs on children or third parties (if the practice is permitted), ${ }^{527}$ or some other reason to suspect that the decision-making process was tainted. ${ }^{528}$

Thus, it could be that the test requires that differently-situated decision makers apply it differently. Alternatively, perhaps judicial scrutiny should be the norm to police the line between Free Exercise and Establishment Clause

522. Supra Part IV.A.

523. See Michael Gentithes, Precedent, Humility, and Justice, 18 Tex. WESLEYAN L. REV. 835, 838 (2012) (discussing judicial reliance on precedents and treating like cases alike).

524. See supra Part IV.B.1 (noting that policymakers should enforce the first and second prongs of the proposed test).

525. See Levin, Rethinking Religious Minorities, supra note 1, at 1669-70 (explaining the "preference for policymaking through political engagement rather than through judicial fiat," especially because "judges do a poor job of protecting unpopular religions").

526. See, e.g., id. at 1665 (discussing an ordinance that was "rife with evidence of animus towards practitioners of Santería" (citing Church of the Lukumi Babalu Aye, Inc. v. City of Hialeah, 508 U.S. 520, 534-35 (1993))).

527. See supra Parts IV.C.1-2 (discussing the application of the test to these populations).

528. See Levin, Rethinking Religious Minorities, supra note 1, at 1683 ("In the absence of institutional advantages or evidence that the political system is systematically incapable of taking religious claims of conscience seriously, courts should generally defer to those policy decisions, whether or not they are sound."). 
interests at stake. We do not have a firm view of which approach is optimal in these difficult cases and suggest that further consideration is warranted.

\section{Conclusion}

There are certain goals for which it is worth unleashing the potential violence of the state-certain evils that the state should right-even at the risk of a mutually damaging confrontation between the state and component minority religious groups. But for both idealistic and pragmatic reasons, liberal states should temper their coercive instincts in many cases and adopt an accommodationist attitude. In the contemporary United States, there is already a marked tendency toward accommodationism, but it is inconsistently reflected in the law and, worse, often lacks principled application. ${ }^{529}$ Too often, the decision of whether to accommodate or prohibit a particular religious practice is driven by interest group politics rather than by thoughtful policymaking.

Our test is a step forward in that it offers a consistent and principled approach to these questions that does not simply leave them to the interest group dynamics of the political marketplace. Instead, the test balances the needs of the state and those of religious people by simultaneously acknowledging the state's need to protect itself and its citizens from religious practices that impose costs on others, while also respecting the values of pluralism. It also incorporates and respects constitutional church-state doctrines and suggests a way to resolve abiding tensions between the Free Exercise and Establishment clauses. Finally, the test can serve as a valuable tool for different kinds of decision makers-legislators, administrative officials, judges, and clinicians-and is sensitive to the relative institutional strengths and weaknesses of each.

529. See supra Part II (considering the inconsistent accommodation practices of government and judicial entities). 